\title{
Incidencias de los patrones de poblamiento en el cálculo de la población del Partido de Atacama desde 1752 a 1804: Las revisitas inéditas de 1787-1792 y 1804
}

JoRge Hidalgo L. ${ }^{1}$

\begin{abstract}
RESUMEN
Se presentan y discuten datos de valor demográfico de algunos empadronamientos inéditos de tributarios que van desde 1752 a 1804. A pesar de sus irregularidades, se busca una explicación en el patrón de poblamiento o en sus características culturales, utilizando las fuentes señaladas e información adicional contemporánea o posterior a estas visitas. Se encuentran claras referencias de que la población atacameña muestra durante varios siglos patrones tanto de trashumancia como de control simultáneo de recursos apartados, estrategia que Murra ha llamado "verticalidad". Su presencia en Atacama relativiza los datos demográficos en cuestión, no pudiéndose determinar con precisión qué población que se consideraba a sí misma atacameña vivía en esa provincia colonial y cuánta vivía fuera de ella.
\end{abstract}

\section{Introducción}

Rafael Altamira, en 1913, prologando el libro de Bautista Saavedra (1938), El ayllu, comenta:

"Cierto es que mucho de la historia se nos escapa hoy y se nos escapará siempre, por falta de noticias, de documentos y monumentos, incluso lo más externo de ella; que en lo interno e inefable de la obra humana casi entera se evapora en alas del tiempo; pero contra esos vacíos inevitables no es aconsejable el relleno de hipótesis, sino la franca confesión de nuestra impotencia".

Sin desconocer que Rafael Altamira tenía mucha razón cuando hacía estas afirmaciones, debemos también enfatizar que merced al descubrimiento de nuevas fuentes, técnicas e hipótesis que se están probando en estos días, las ciencias históricas logran completar algunos de esos vacíos. Y es que:

"Por motivos económicos, administrativos y religiosos, y por razón de mantener más o menos al día un inventario de los recursos materiales y humanos de sus posesiones en el Nuevo Mundo, españoles y

1 Depto. de Antropología, Universidad del Norte, Arica, CHILE. portugueses produjeron desde el momento mismo de la ocupación territorial una serie de documentos que contenían una clara intencionalidad estadística. La mayoría de ellos se ha perdido después de siglos, ya sea por destrucción o descuido. Sin embargo, ha sobrevivido un número suficiente como para conocer parcialmente la realidad económica y social de cada época y cada lugar” (Mellafe 1972: 1).

Entre estos documentos que han atraído la atención de los investigadores por su valor estadístico, pero también como lo destacó Arguedas (1964: VIII), por los "detalles vívidos" que describen "un grupo étnico local, un valle en particular, una agrupación humana específica”, están las visitas. Murra (1975: 281) invita a seguir en la tarea de describir y publicar nuevas fuentes que nos permitan comprender los logros del hombre andino y asegura:

"Los textos de alta prioridad en nuestra época revelarán datos sobre instituciones andinas que perduraron, que largamente precedieron a la conquista inca y a las que ni siquiera la invasión europea logró desarraigar. El ecosistema andino, los cultivos, los métodos andinos para controlar la altura o el agua, la percepción andina de lo que podía ser un recurso: todos estos logros andinos perdurables necesitan estudios etnohistóricos".

El norte de Chile es una zona reputada por la ausencia de documentos históricos, particularmente de la época hispánica. En parte, tal situación se explica por sus características físicas y su aislamiento de los principales centros de administración colonial (Casassas 1974: 11). Además de escasa, esta documentación se encuentra desperdigada en archivos de diferentes ciudades y países en la medida en que ha cambiado la jurisdicción estatal a que han estado sujetas estas regiones:

"Desde 1559, el Distrito de Atacama formó parte de la Audiencia de Charcas, integrante del Perú. Dos siglos más tarde, cuando se creó el Virreinato del Río de la Plata, en 1776, pasó a incorporarse 


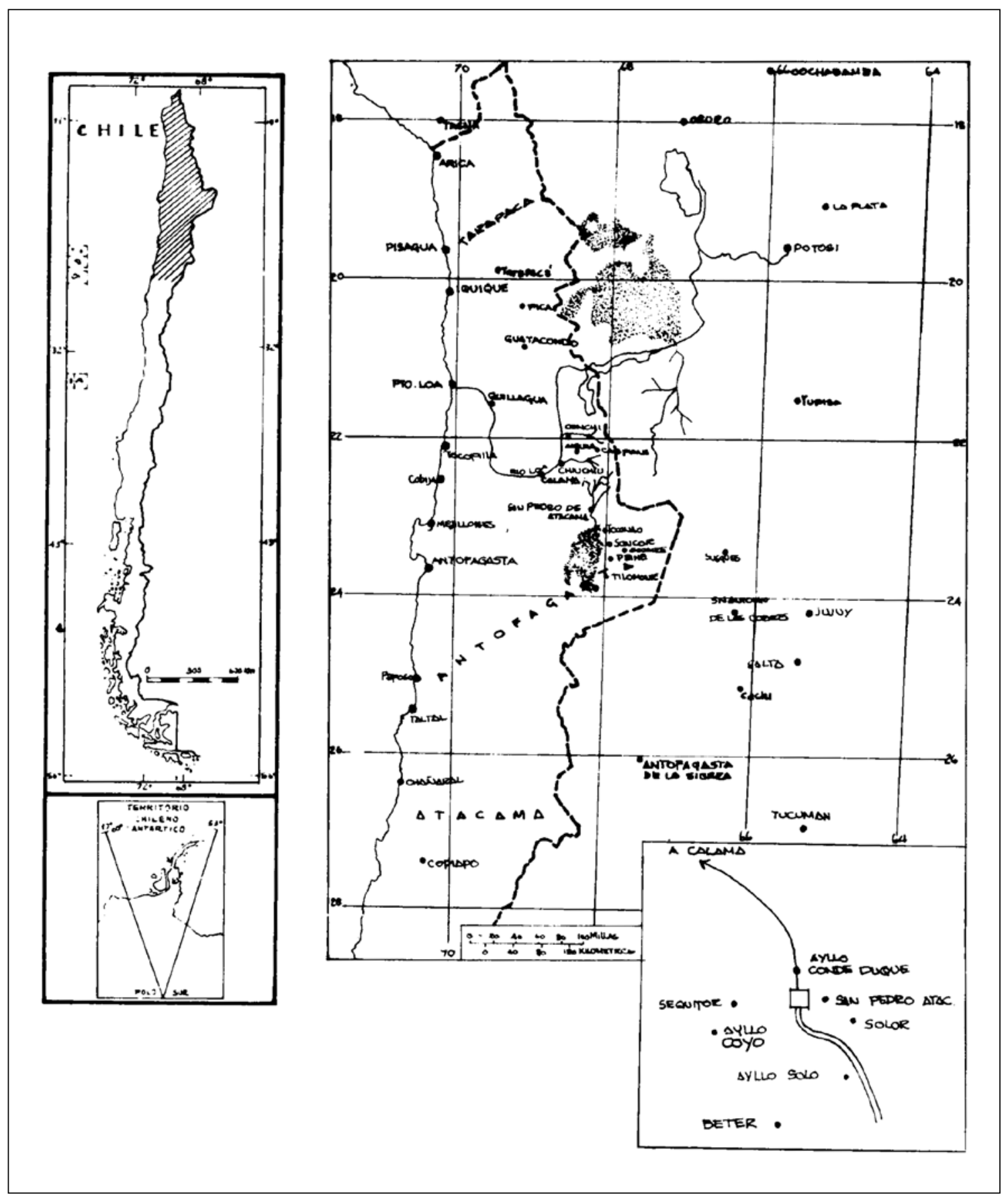

Figura 1. Atacama y su contexto geográfico. Mapa del Desierto y Puna de Atacama según Bowman (1924).

La publicación de los mapas de esta figura y de la Figura 2 ha sido autorizada por la Dirección de Fronteras y Límites del Estado en la Resolución 290 de diciembre 1 de 1978 en conformidad con el Artículo 3 de la Ley 16592. 


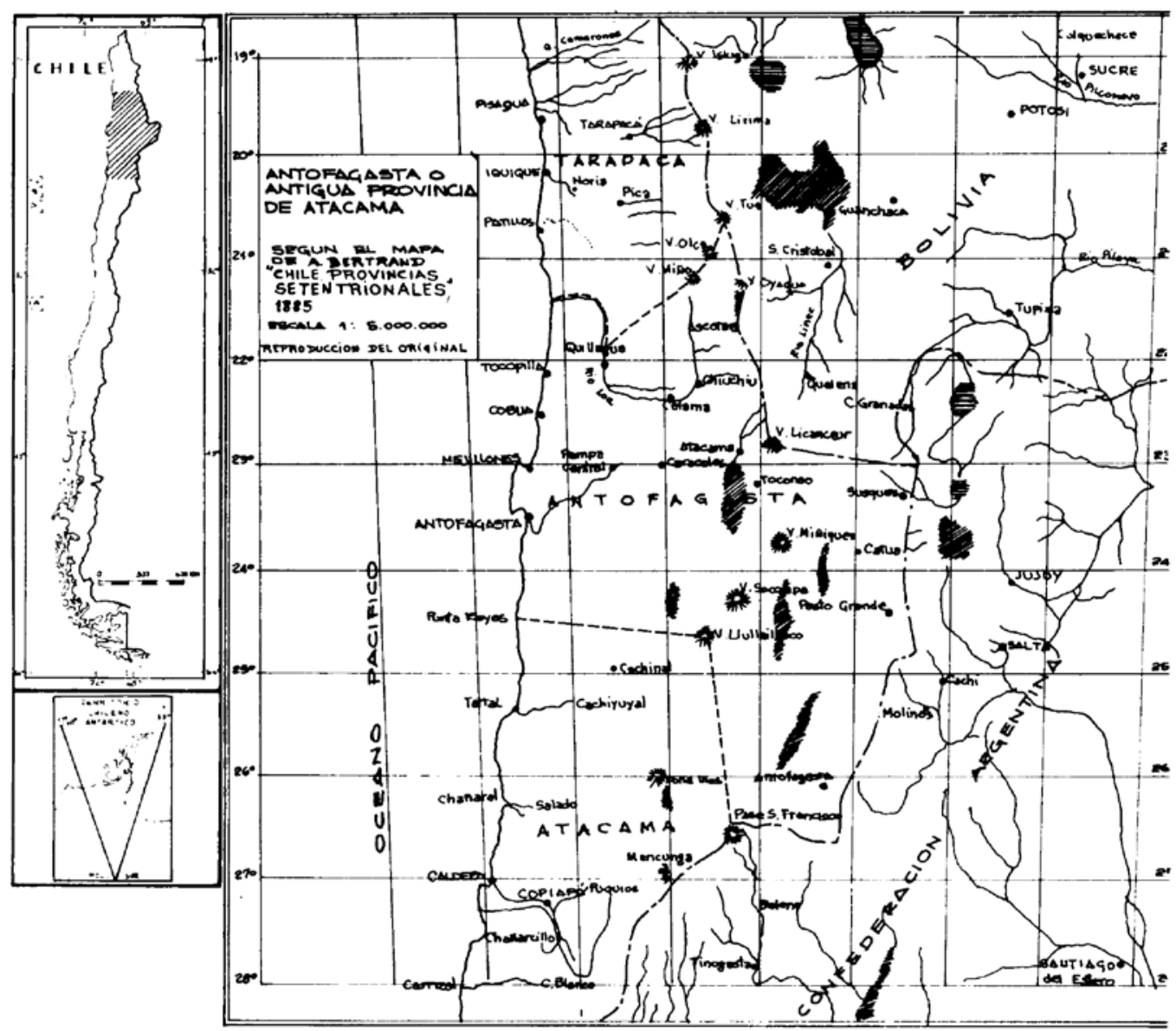

Figura 2. Antofagasta o antigua provincia de Atacama. 
a la provincia de Potosí, dependiente del nuevo Virreinato" (Espinosa Moraga 1958: 13).

En agosto de 1975, respaldados por la Universidad del Norte, sede Arica, viajamos a Sucre para consultar el Archivo Nacional Boliviano (ANB) que conserva la documentación de la Real Audiencia de Charcas. Allí, gracias a las sugerencias y a la excelente catalogación del archivo que ha hecho su director Gunnar Mendoza y trabajando en colaboración con el Dr. Murra, que se encontraba en esos días en Sucre, pudimos ubicar, leer y microfilmar más de 20 piezas sobre el pasado etnohistórico del Norte Grande de Chile; de éstas, 15 pertenecen al Corregimiento o al Partido de Atacama. ${ }^{2}$ En el Anexo 1 publicamos la "Revisita del Partido de Atacama concluida el 10 de junio de 1804", inédita hasta ahora. Más tarde, el mismo año 1975, pudimos microfilmar en el Fondo Medina de la Biblioteca Nacional, Santiago, los resúmenes y documentos complementarios de las visitas de 1787 y 1792 del Partido de Atacama, citados por el Repertorio Bibliográfico 3 publicado por Casassas y que permanecían igualmente inéditos (también se incluyen en el Anexo 1). Más adelante hacemos una descripción somera de estos documentos. Por último, en lo que se refiere a nuestras fuentes, sabemos que en el Archivo General de la Nación Argentina se guardan los padrones y revisitas de los indios de Atacama de 1787, 1792, 1797, 1804 (Figuras 1 y 2 ). ${ }^{3}$

Nuestro objetivo al publicar estas fuentes de carácter rentístico e intentar una primera aproximación a los datos, fue trazar una curva de población que fuese expresiva del movimiento demográfico del Partido de Atacama. Esperábamos que tal curva fuera un indicador de primera mano del dinamismo de los

2 La mayor parte de estos documentos, con excepción de los que se incluyen en este volumen y Chungara 6 serán publicados en Estudios Atacameños.

3 Documentos sobre la Historia de Bolivia existentes en el Archivo General de la Nación Argentina, Universidad Mayor de San Andrés, nota preliminar del recopilador René Arce, La Paz, 1975. Horacio A Difrieri, publica, además, una noticia con fecha de mayo 20 de 1974, en Estudios Atacameños 2, en que se da cuenta que el Instituto Interdisciplinario Tilcara (Jujuy, Argentina) está investigando problemas de demografía colonial de la provincia de Atacama con padrones del siglo XVII existentes en el Archivo General (Buenos Aires). Estamos haciendo los trámites para obtener los microfilmes, con los cuales este trabajo podría sustentarse en fundamentos documentales; en tanto, hemos decidido abordar el tema otorgándole al presente estudio un carácter preliminar. procesos económico-sociales a los que habrían estado sujetos los habitantes indígenas de la región atacameña en la segunda mitad del siglo XVIII, de modo que sus alzas y bajas pudieran conducirnos a las coyunturas más significativas, pues, como dice Stockwell (1970):

"Estoy firmemente convencido de que el conocimiento de las características demográficas objetivas de cualquier población -su tamaño, las características de sus miembros, su distribución en el espacio y sus pautas de crecimiento y cambio-es un requisito previo fundamental para comprender los diversos problemas sociales que ella enfrenta".

Para conseguir esa curva fue necesario hacer un examen minucioso de las fuentes, averiguar qué tipo de población era empadronada y hasta qué punto esa población era representativa de la población total. Una vez obtenido esto ordenamos los datos y trazamos un gráfico. El resultado era desconcertante aun cuando la población parecía crecer entre 1752 y 1804 , entre 1787 y 1792 experimentaba una muy fuerte disminución que se resistía a ser explicada por las dos variables más significativas en estos casos: epidemias o migraciones. Fue necesario buscar una tercera explicación que resultara realmente eficiente. La respuesta estaba contenida en nuestros papeles y en parte se encontraba en un documento parcialmente transcrito por Murra y publicado por Serracino (1974) y que si bien hace perder validez a la curva de población a la que habíamos arribado, nos permite documentar otros aspectos de la vida atacameña que no habíamos pensado tratar al iniciar este trabajo; nos referimos básicamente a "verticalidad" (Murra 1972), patrón de poblamiento y de uso de recursos que en el mundo andino se remonta a tiempos anteriores al Período Incaico (Lumbreras 1974) y que en el caso atacameño (siglo XVIII) es una utilización de pisos complementarios en el Noroeste Argentino.

La baja de población entre 1787 y 1792 no refleja una baja real de la población sino un cambio en la forma de censar, provocado por una distinta consideración de las autoridades del factor anteriormente indicado.

En lo que se refiere a las características de la población, no pretendemos agotar toda la rica información demográfica que es susceptible de ser extraída de estos papeles. Los demógrafos, en base a técnicas más refinadas que las nuestras y a la comparación con 
fuentes y modelos de otras situaciones, seguramente profundizarán, ampliarán o modificarán lo que aquí se diga. Más bien pretendemos prevenir a los demógrafos sobre las dificultades o las interpretaciones culturales que ofrecen estos datos.

Del mismo modo, lingüistas, estudiosos del parentesco u otros especialistas descubrirán en el estudio de la toponimia o de los apellidos informaciones que nosotros no estamos en condiciones de apreciar. ${ }^{4}$

\section{Las fuentes: Breve descripción de los documentos anexos}

\section{Revisita de 1804}

Se trata de un todo compuesto de tres partes: el "Quaderno Primero" es el "testimonio de la revisita, numeración y empadronamiento de Yndios practicada en el beneficio de San Pedro de Atacama por su Juez Subdelegado Dn. Pedro Antonio de Gurruchaga", corre de la foja 1r a la f28r; el "Quaderno Segundo" es el "Testimonio de la Revisita, numeración y empadronamiento de los Yndios, practicada en el beneficio de San Francisco de Chiu Chiu, Atacama La Vaja, por su Juez Real Subdelegado Don Pedro Antonio de Gurruchaga", se extiende de la foja 1r a la f14r. A estas 42f. se agrega un cuadro resumen de la visita. ${ }^{5}$

4 Hemos procurado ser cuidadosos en la transcripción paleográfica. Por sugerencia del historiador arequipeño Dr. Alejandro Málaga, nos hemos ajustado a las normas internacionales vigentes, aprobadas en la Primera Reunión Interamericana sobre Archivo, celebrada en Washington D. C. en octubre 27 de 1961, con excepción de la regla que recomienda uniformizar la ortografía de las "b" y "v". En cambio, hemos desarrollado las abreviaturas, excepto las de nombres propios, hemos eliminado las doble tt, etc., de acuerdo a las normas citadas. Una vez finalizada la transcripción que hicimos con la colaboración de Nelda Maggi, el documento fue revisado por Julia Córdova para verificar que no se hubiesen cometido errores y frente a cada duda hemos vuelto al microfilm. Por último, en el caso de la visita de 1804 , hemos cambiado las dos columnas de nombres de tributarios que tenía cada foja por un texto simple respetando o indicando los cambios de foja.

5 Para los fines de cita, al referirnos a este documento lo haremos con las siglas $\mathrm{Ra}$, si es el cuaderno primero y $\mathrm{Rb}$ si es el cuaderno segundo; a continuación anotaremos el número de la foja y la letra "r" si es "Recto" y "v" si se trata de la hoja vuelta. Por ejemplo, un dato del primer cuaderno, hoja 10 reverso, se anotará así: Raf10v.
Aparte de las tres primeras fojas en que Gurruchaga da por concluida la visita que "se inició en la capital de San Pedro de Atacama y se terminó en este Asiento de Conchi -último- pueblo de la doctrina de San Francisco de Chiu Chiu" (Raf1r), emite las órdenes correspondientes para que se saquen las copias necesarias, el texto está compuesto por la lista de los tributarios "que se hallan matriculados, especificando... el nombre del tributario, el de su mujer, hijo, hijos o allegados que pasen de los trece años los que se denominan por próximos" (Raf1v/f2r). Se anota, además, la edad de los tributarios, hombres de 18 a 50 años. Estos padrones se obtenían sobre la base de las "declaraciones correspondientes en forma de derecho' que hacían los "gobernadores, caciques y alcaldes", quienes se presentaban a declarar por las subunidades geográficas-políticas que componían los respectivos curatos o repartimientos, vale decir, ayllus, pueblos y anexos. Estas subunidades eran: a) En el repartimiento de San Pedro de Atacama: 1. ayllo de Conde Duque; 2. ayllo de Sequitur; 3. ayllo de Collo o Coyo; 4. ayllo Betere o Vetere; 5. ayllo de Solo; 6. ayllo de Solcor; 7. pueblo de Toconao; 8. pueblo de Soucor o Soncor; 9. pueblo de Socayre o Socaire; 10. pueblo de Peyne; 11. anexo de Susquiz o Susquis.

b) En el repartimiento de San Francisco de Chiu Chiu: 1. el ayllo del Pueblo; 2. pueblo de Caspana; 3. pueblo de Aquina o Ayquina; 4 . pueblo de Calama; 5 . puerto de Cobixa o Cobija; 6. asiento de Conchi.

Valdría la pena agregar que el gobierno indígena de los repartimientos lo tenían bajo la tuición del subdelegado y antes del Corregidor un "Gobernador y su Segunda Persona", quizá una reminiscencia del sistema dualista (Ponce 1975: 8), del cual quizá también lo sea la división de Baja y Alta Atacama. En las subunidades encontramos también autoridades dobles, pero esta vez se debe a la superposición de la autoridad étnica tradicional, el "Curaca" o "Cacique" y el "Alcalde" representante del cabildo indígena impuesto por los españoles (Spalding 1974; Hidalgo 1977).

En la época era frecuente que el visitador se auxiliara con los libros parroquiales para verificar si las declaraciones de los caciques se ajustaban a la verdad, como en el caso de Calacoto en $1714^{6}$ y

6 La visita aludida se encuentra en el ANB. Documento E, $1748, \mathrm{n}^{\circ} 63$ 
Tiwanaku en 1773 (Ponce 1975: 18). Aun cuando no sabemos si Gurruchaga adoptó estas medidas de precaución, advierte que "se hicieron otras averiguaciones secretas, para evitar cualquier perjuicio al Real Erario, dejando a salvo el derecho de $\mathrm{Su}$ Majestad (que Dios Guarde) por si en algún tiempo resultare aumento por fraude, u ocultación que se justifique" (Raf2v).

\section{Revisitas de 1787 y 1792}

En el Fondo Medina de la Biblioteca Nacional de Chile pude leer y microfilmar un grupo de documentos relativos a las visitas de 1787 y 1792 citados por Casassas en el Repertorio Documental 3. En esa publicación figuran con los números 291-295300-301-302-354 y 359. Son copias manuscritas hechas en España por J. T. Medina, de la Colección Mata Linares de la Biblioteca de la Real Academia de la Historia, Madrid. ${ }^{7}$ De acuerdo al Repertorio de Casassas, se trata de documentación inédita, pero no desconocida. Este mismo historiador ha citado el resultado numérico de la revisita de 1787 y un párrafo de los documentos que la acompañan (Casassas 1974a: 49, 1974b: 91-92).

No se trata de visitas completas, como la de 1804 , sino de los informes, resúmenes y comentarios de los visitadores dirigidos a las autoridades de la Intendencia de Potosí y del Virreinato de Buenos Aires, para dar curso a las modificaciones tributarias y las respuestas de los funcionarios pertinentes. Carecemos de los nombres y edades de los tributarios, pero tenemos las cifras de los resúmenes y una rica información cualitativa que podemos cotejar con otras fuentes. Además, por los comentarios, sabemos de los resultados de otras dos revisitas anteriores a las de 1752 v $1777 .{ }^{8}$ Como puede apreciarse, estos empadronamientos eran frecuentes, pero no tanto como lo ordenaban las disposiciones coloniales. Así, en 1792 se dice "habiéndose cumplido el período de los cinco años que debe mediar de una a otra Revisita, y ser necesaria la actuación de otra..." (Mf41r) "los padrones en muchas ocasiones no se renovan en una o dos décadas y en algún caso inclusive en 40 años,

7 Para los efectos de cita, al referirnos a estos documentos lo haremos bajo el sínbolo "M", y a continuación indicaremos la foja.

8 Aun cuando en este caso se trata de copias manuscritas de documentos originales y no tenemos seguridad de que se ha conservado la ortografía original, hemos seguido las normas de transcripción ya señaladas. lo que beneficiaba a los corregidores, que cobraban a los nuevos tributarios sin rendir cuentas" (Ponce 1975: 24). Precisamente este caso en que tenemos dos visitas en un quinquenio sucede algunos años después que se ha puesto fin al sistema de corregimientos que dio origen a esas situaciones. ${ }^{9}$

\section{Composición de la población tributaria}

Antes de analizar la curva de población es necesario distinguir las diferentes categorías de tributarios que reconocen estos padrones. Teóricamente estos documentos registran valores indígenas en edad de tributar (quedaban excluidos de ellos blancos y negros sometidos a un régimen legislativo diferencial), pero si leemos los cuadros resúmenes nos encontraremos con tres tipos de tributarios, de los cuales uno no correspondería a la definición colonial de indio. Las "castas", para emplear el lenguaje de los documentos de la época, eran: 1) originarios; 2) forasteros, con y $\sin$ tierras, y 3 ) cholos, con y sin tierras.

\section{Originarios y forasteros}

Tenemos la impresión que originarios y forasteros con tierras en estas visitas se incluyen en una sola categoría, por lo menos así es en $1804 .{ }^{10}$ Las diferencias en el pago de tributo estaban determinadas por la posesión o no de tierra, en el caso de Atacama. Rosenblat (1954) señala en relación a indígenas y tributos:

"Aunque el indio era vasallo libre y tenía acceso a la riqueza y al libre disfrute de sus bienes (consta efectivamente que hubo indios ricos en todo el Período Colonial) estaba sometido a una serie de deposiciones especiales (deberes y derechos) que los distinguían jurídica y socialmente de las demás castas:

9 Sobre el corregidor de indios en Atacama, ver Hidalgo (1977).

10 Con excepción del ayllo de Solcor, donde se detalla a los forasteros con tierras, ver Rafl6v. Murra (com. pers.) indica que ya a fines del siglo XVII el duque de La Palata trató de eliminar esta diferencia, ya que los forasteros frecuentemente no pasan en ninguna parte... y agrega que los virreyes y los administradores peninsulares trataban de enumerar juntos a todo el mundo, donde los criollos y los hacendados encontraban ventajas en "liberar" a sus peones "forasteros" de obligaciones tradicionales. 
a) Tributo personal. La encomienda del siglo XVI se disolvió paulatinamente en el tributo personal. Los indios pagaban un tributo por cabeza. Desde 1578 sólo lo pagaban los indios de 18 a 50 años y desde 1618 sólo los varones. En 1746 el tributo indígena llegó a sumar la cantidad de 650.000 pesos y en 1807, 1.200.000 pesos (Humboldt, Ensayo IV, 226, libro II, cap. XIII; en otro pasaje dice que el tributo indigena sumaba 1.300.000 pesos sobre una renta total de 20 millones). En cambio, los indígenas estaban exentos de todo impuesto directo y no pagaban alcabala. El importe del tributo variaba en las distintas regiones y según Humboldt había disminuido en los últimos 200 años; en 1601 era de 32 reales de plata y 4 reales de servicio real; en algunas intendencias se redujo a menos de la mitad y hasta un sexto (Carrancá y Trujillo dicen que era de 16 reales anuales, o sea, 2 pesos y además un real para ministros de culto y hospital). Pagaban también derechos parroquiales (por bautismo, casamiento o entierro) y ofrendas voluntarias. Los caciques y herederos de los monarcas indígenas estaban exentos de pago de tributo. También, por los servicios prestados a la corona, los tlascaltecas. En casos de escasez o calamidad pública había moratoria para el pago, o se les podía dispensar del pago cuando había causa justificada. Una parte del tributo se dedicaba a los hospitales indígenas" (Rosenblat 1954, II, 145-146).

Originarios, forasteros y cholos con tierras pagaban 5 pesos en cada tercio de San Juan y Navidad. ${ }^{11}$ No era así en todas partes. ${ }^{12}$

11 Ponce comenta, refiriéndose a este pago semestral llamado tercio: "Salta a la vista la incongruencia de la denominación tercio" (1975: 23); Barandas (1973: 162) en una nota en que explica el término "Tercio de San Juan", dice: El tercio de San José (sic): Tercera parte del tributo anual, cuyo pago se hacia efectivo en esta festividad (19 de marzo)". Los documentos que manejamos indican que la intención fue establecer tercios de cuatro meses, pero en esta provincia, debido a lo disperso del poblamiento, se hacía impracticable su cobranza (ver Mf25r).

12 "Originarios, dice el subdelegado de Omasuyos, Marqués de la Plata, son aquellos que tuvieron su primer origen en el ayllo, en que a la actualidad se miran existentes y se conciben solariegos, como que logran dicho su origen anticuado en aquellas tierras, nominando ayllo lo que nosotros Repartimiento. Estos por lo mismo se suponen de superior calidad y aun se tienen por mejores que los yanaconas, forasteros y uros, de forma que entre ellos el originario es más recomendable que los forasteros para exercitar empleos públicos, gozar más tierra en su ayllo, alcanzar el mejor lugar, contribuye al tributo de cuota superior, cual es el de diez pesos y sufren
Debe señalarse que los atacameños no contribuyeron con la mita de Potosí, lo que no los excluía de mitas locales en minas o tierras del Corregidor. Es probable que los originarios ocuparan un rango superior a los forasteros y cholos dentro de su ayllo (ver nota 12).

Los forasteros con tierras los pensamos como indígenas vinculados a otras comunidades, pero que viven permanentemente en el área atacameña, tal como sucedía con los indígenas de Atacama que eran reputados como originarios en Atacama pero eran considerados forasteros en Calchaquí, lugar donde residían (Casassas 1974b: 108-109). Cassasas, a través de los documentos parroquiales del siglo XVII, detecta un numeroso grupo de forasteros:

"Algunas de estas personas, posiblemente, estuvieron sólo de tránsito y su actuación reflejada en el Libro fue por tanto circunstancial; pero en diversos casos un determinado nombre aparece varias veces en distintos años, de lo que podría inferirse una residencia normal o prolongada" (1974: 45).

Los forasteros sin tierras pagaban siete pesos al año, al igual que las otras categorías de tributarios que carecían de este importante medio de subsistencia. Por el calificativo que reciben pareciera tratarse de indígenas sin arraigo en Atacama y orientados hacia actividades no agrícolas, probablemente la minería. Nuestros documentos, justificando su bajo número en el Partido, señalan:

"A excepción de los forasteros que se hallan agregados al Asiento de Conchi, y de uno tal que otro entre los pueblos, y ayllos de su Jurisdicción no hay número de los de esta clase como regularmente se echa de ver en aquellos Partidos que abundan de Minas, u otros lucrosos exercicios, cuando no ofresca el mejor acogimiento en la fertilidad del Terreno" (M f25r).

\footnotetext{
las pensiones de la mita de Potosí. Forasteros (agregados) son los que no teniendo en aquel repartimiento su origen ni confundiéndose con la nobleza de dichos originarios aparece como agregándose a las tierras de comunidad (de las que se les asignan las necesarias para su cómoda subsistencia), pagan cinco pesos de tributo al año y sufren la pensión de la enunciada mita, como ayudando a los originarios" (Saavedra 1938: 135-136, citando el Informe del Subdelegado de Omasuyos, Marqués de La Plata, al Intendente de La Paz. Coscocha, mayo 2 de 1972. Academia de la Historia, Madrid. Colección Mata Linares, vol. 3).
} 
Cholos

Con sólo la excepción de una persona en Cobija, 1787, todos los demás cholos mencionados en estas visitas poseen tierras. Si cholo es en el Alto Perú colonial un mestizo, como afirma Otero (1975: 18), las visitas estarían expresando el cambio de estatus sufrido por esta población a fines de ese período. No obstante, parece que la palabra "cholo" está referida a un tipo específico de mestizo, a la combinación entre indígena y mestizo. En la misma época, al menos en Atacama, se usa el término "mestizo" para la combinación de español con indígena y éstos no son considerados tributarios, por el contrario, sirven de instrumento a las autoridades españolas sobre los indígenas; uno de ellos es calificado como "un mero Ministro de sus mercedes las Justicias Mayores"(ANB, E, 1758, nº 64, f12v).

Spalding (1974: 166) afirma: "En el siglo XVII, sólo un cuarto de ancestro español -la definición fiscal de un cholo- era suficiente para eximir a un individuo de la carga de trabajo forzado". Empero "alrededor del siglo XVIII... se asignaba una posición legal a la combinación de indio con mestizo, el cholo. Este estaba liberado de la mita aunque estaba sujeto al pago de tributo" (Spalding 1974: 82).

La inclusión en las visitas a estos cholos con tierras pareciera indicar que estos mestizos de Atacama no sufrieron la evolución que describe Carmagnani (1963) en los orígenes del salariado minero del Norte Chico. No conocemos la legislación que reglamentó la incorporación de los cholos en el trabajo de la tierra como tributarios empadronados. ${ }^{13} \mathrm{Sin}$ embargo se puede suponer que el incremento de los grupos mestizos obligó desde el siglo XVII a las autoridades españolas a intentar su participación en el sistema rentístico fiscal, obligándolos a trabajar "en las labores agrícolas, en las minas y en trabajos públicos" (Spalding 1974: 166). La extensión del tributo fue, a juicio de Vargas Ugarte (1956: 372), otra de las razones que explican las rebeliones indígenas del siglo XVIII:

13 Spalding (1974: 82) cita para este propósito a Antonio Porlier: "Instrucción de Capítulos que han de observar los jueces revisitadores...". En Libro de cédulas, autor acordados y otros instrumentos pertenecientes a los indios, año de 1760, Biblioteca de la Universidad de Yale, Lib. II, Fol. 93, microfilm en la Biblioteca Bancroft, Universidad de California, Berkeley, en Documents Relating to Perú, Carril 2.
"Desde el momento en que comenzó a extenderse la tributación a los mestizos, cholos y otras castas y, en general, a toda la gente libre, porque sólo se exceptuaban a los esclavos, las protestas comenzaran a brotar y siendo la causa común todos se dieron la mano para alzarse contra ella. Mientras los quintos reales procedentes de la plata y oro de las minas y los tributos exigidos al indígena bastaban a las necesidades del erario, no se pensó en gravar con una contribución personal a las demás castas, pero la decadencia de los asientos mineros y aun la disminución de los indios, obligaron a hacer extensivo a todos el tributo...”.

En esta situación es probable que la vida de estos "cholos" fuese muy similar a la de los agricultores indígenas, aun cuando deben haber estado excluidos de participar en los cargos que estaban abiertos a los originarios dentro de la sociedad colonial.

En el Cuadro 1 se muestra el peso numérico y porcentual de cada una de estas categorías en las visitas de 1787-1792 y 1804 .

La población mestiza que se incluye en estas tres visitas era francamente minoritaria. Su porcentaje en el total respectivo de tributarios es de un $3.7 \%$ en $1787,4.4 \%$ en 1792 y $3.8 \%$ en 1804 . Vale la pena adelantar que el $4.4 \%$ de 1792 corresponde a un instante en que el número de tributarios registrados ha descendido notablemente, de modo que aún bajando el número de "cholos con tierras" ha aumentado su porcentaje en el total. En el siglo XVI la cantidad de mestizos registrados también parece haber sido baja, según Casassas, en el Libro de varias ojas de Chiu Chiu, sólo se encuentran siete mestizos a lo largo de ese siglo, aunque es probable que un porcentaje de los forasteros registrados en esa misma fuente también lo sean (Casassas 1974a: 43-49).

Si la inclusión de la población mestiza de cholos era total en los padrones del Partido de Atacama de fines del siglo XVIII y comienzos del siglo XIX, cosa que por el momento no podemos aseverar, significaría que el porcentaje de "mestizos-cholos" en el conjunto de la población del Partido era aún muy bajo. En cambio, originarios y forasteros con tierras constituían alrededor del $90 \%$ del total de tributarios. Forasteros sin tierras, esta población que suponemos indígena, no atacameña y no agrícola, es otro segmento con poco significado numérico. En 


\begin{tabular}{|c|c|c|c|c|c|c|c|c|c|c|c|c|}
\hline \multirow{2}{*}{ Categorías } & \multicolumn{4}{|c|}{ Visita 1787} & \multicolumn{4}{|c|}{ Visita de 1792} & \multicolumn{4}{|c|}{ Visita 1804} \\
\hline & $\begin{array}{c}\text { San } \\
\text { Pedro }\end{array}$ & $\begin{array}{l}\text { Chiu } \\
\text { Chiu }\end{array}$ & Total & $\%$ & $\begin{array}{c}\text { San } \\
\text { Pedro }\end{array}$ & $\begin{array}{l}\text { Chiu } \\
\text { Chiu }\end{array}$ & Total & $\%$ & $\begin{array}{c}\text { San } \\
\text { Pedro }\end{array}$ & $\begin{array}{l}\text { Chiu } \\
\text { Chiu }\end{array}$ & Total & $\%$ \\
\hline $\begin{array}{l}\text { 1. Originarios u originarios } \\
\text { con tierras y Forasteros } \\
\text { con tierras }\end{array}$ & $568+\mathrm{A}$ & 108 & 676 & 92.74 & $333+\mathrm{B}$ & 118 & 451 & 89.8 & 398 & 106 & 504 & 090.13 \\
\hline $\begin{array}{l}\text { 2. Forasteros o Forasteros } \\
\text { sin tierra }\end{array}$ & 4 & 21 & 25 & 3.42 & 3 & 26 & 29 & 5.8 & 5 & 28 & 33 & 5.9 \\
\hline 3. Cholos con tierra & 14 & 13 & 27 & 3.7 & 10 & 12 & 22 & 4.4 & 9 & 11 & 20 & 3.8 \\
\hline 4. Cholos sin tierra & & 1 & 1 & 0.14 & & & & & & & & \\
\hline Total tributarios & 586 & 143 & 729 & 100.00 & 346 & 156 & 502 & 100.00 & 412 & 145 & $\mathbf{5 5 7}$ & 100.00 \\
\hline
\end{tabular}

Cuadro 1. Atacama: Categorías de tributarios y su importancia porcentual. Referencias: +A: E1 extracto de la visita de 1787 anota esta cantidad como suma de los tributarios de San Pedro, pero la suma correcta sería 576; sin embargo, hemos decidido mantener la cifra de 568 dado que es el número utilizado para calcular el tributo y éste supone una revisión de la Contaduría de Retasas. Es probable entonces que el error de la suma se deba a una equivocación en las cifras de los ayllos y pueblos de San Pedro cometida por el copista de Medina. +B: La suma del original debiera ser 363 , pero en base a las mismas consideraciones anotadas en "A" hemos decidido mantener la cantidad utilizada para calcular los ingresos fiscales.

el total de tributarios, representa un $4.42 \%, 5.8 \%$ y $5.9 \%$ en 1787,1792 y 1804 , respectivamente.

\section{Algunos datos sobre la estructura demográfica de la población en $\mathbf{1 7 8 7}$}

Otra perspectiva que estas fuentes permiten consultar, aunque someramente, es la relativa a la composición de las familias nucleares, biológicas o conyugales en cada uno de los diferentes tipos de población tributaria a los que hace mención la Revisita de 1787. Emplearemos para esto las cifras aportadas por la "Demostración de la contaduría de retasas sobre el número de contribuyentes empadronados en la Revisita del Partido de Atacama en el año 1787".

Dentro de las categorías masculinas hay dos que requieren una breve explicación: ausentes y reservados. Ausentes son los hombres en edad de tributar, pero que han abandonado su comunidad "sin saberse de ellos" (Mf25r). Los 251 reservados de esta visita "se compone en 201 mayores de 50 años o impedidos, 9 sirvientes de iglesia, 5 por enfermedad temporal, 11 Alcaldes, 5 Governadores, 14 Curacas, y 3 segundas" (Mf31r).

Se puede apreciar en el Cuadro 2 que en todos los casos el número de casados es inferior al número de tributarios (con excepción de los cholos sin tierras), siendo el total de tributarios 729 y las casadas sólo 597. Sin embargo, es probable que el número de sociedades conyugales, permanentes o no, fuese mayor si se considera el elevado número de mujeres que son calificadas como "solteras" y en menor proporción "viudas". ${ }^{14}$

14 Bowman, en un subtítulo dedicado a describir las "costumbres y creencias ancestrales" de los habitantes de Susques, anota: "Cierto número de niños nacen fuera del matrimonio, pero no vacilan en declararlo y en darles el nombre de los padres. Gran número de mujeres tienen hijos de diferentes padres antes del matrimonio y el número de hijos aumenta las posibilidades de matrimonio de una joven madre, pues los niños constituyen una especie de dote en el matrimonio, ya que cada uno de ellos puede hacerse cargo del cuidado de cierto número de ovejas o llamas desde la edad de siete u ocho años. Esos niños son adoptados por el padre en el momento del matrimonio y son considerados iguales a los hijos legítimos nacidos después. La fortuna de un individuo depende considerablemente del número de hijos que tiene, porque esto determina el número de animales que pueden hacer pastar. Mientras que las relaciones libres se toleran dentro de la tribu, las relaciones entre una mujer y un extranjero, sea éste indio o no, se castigan inmediatamente con la expulsión de la tribu. De 22 parejas de casados en Susques, sólo dos no tenían hijos en el tiempo en que se estudió esta aldea. Las otras veinte tenían setenta y nueve hijos, cuarenta y cuatro muchachos y treinta y cinco niñas" (Bowman 1942: 360). 


\begin{tabular}{|c|c|c|c|c|c|c|c|c|c|c|c|}
\hline & \multicolumn{3}{|c|}{$\begin{array}{l}\text { Originarios con } \\
\text { tierra de } 10 \mathrm{ps.}\end{array}$} & \multicolumn{3}{|c|}{$\begin{array}{l}\text { Cholos con } \\
\text { tierra de } 10 \mathrm{ps.}\end{array}$} & \multicolumn{3}{|c|}{$\begin{array}{l}\text { Forasteros sin } \\
\text { tierra de } 7 \mathrm{ps.}\end{array}$} & \multirow{2}{*}{$\begin{array}{c}\begin{array}{c}\text { Cholos } \\
\text { sin tierra }\end{array} \\
\begin{array}{c}\text { Chiu } \\
\text { Chiu }\end{array}\end{array}$} & \multirow{2}{*}{ Total } \\
\hline & $\begin{array}{c}\text { San } \\
\text { Pedro }\end{array}$ & $\begin{array}{l}\text { Chiu } \\
\text { Chiu }\end{array}$ & Total & $\begin{array}{l}\text { San } \\
\text { Pedro }\end{array}$ & $\begin{array}{l}\text { Chiu } \\
\text { Chiu }\end{array}$ & Total & $\begin{array}{c}\text { San } \\
\text { Pedro }\end{array}$ & $\begin{array}{l}\text { Chiu } \\
\text { Chiu }\end{array}$ & Total & & \\
\hline Tributarios & 568 & 108 & 676 & 14 & 13 & 27 & 4 & 21 & 25 & 1 & 729 \\
\hline Ausentes & 54 & 5 & 59 & 1 & & 1 & 1 & & & 3 & 64 \\
\hline Próximos & 161 & 37 & 198 & 7 & 2 & 9 & 1 & 4 & 5 & 1 & 213 \\
\hline Niños & 374 & 126 & 500 & 16 & 13 & 29 & 1 & 18 & 19 & & 548 \\
\hline Casadas & 467 & 95 & 562 & 9 & 5 & 14 & 4 & 14 & 18 & 3 & 597 \\
\hline Solteras & 501 & 77 & 578 & 9 & & 9 & 1 & 6 & 7 & & 594 \\
\hline Viudas & 138 & 15 & $153^{*}$ & 2 & 1 & 3 & & 3 & 3 & & 159 \\
\hline Niñas & 384 & 82 & 466 & 13 & 4 & 17 & 1 & 14 & 15 & 2 & 500 \\
\hline Reservados & 203 & 40 & 243 & 3 & & 3 & & 4 & 4 & 1 & 251 \\
\hline Total & 2850 & 585 & 3435 & 74 & 38 & 112 & 13 & 84 & 97 & 11 & $3655^{* *}$ \\
\hline $\begin{array}{l}\text { Relación entre } \\
\text { población total y } \\
\text { el nº de tributarios }\end{array}$ & 5.01 & 5.63 & 5.08 & 5.28 & 2.92 & 4.14 & 3.25 & 4.00 & 3.88 & 11 & 5.01 \\
\hline $\begin{array}{l}\text { Número total de } \\
\text { hombres y \% }\end{array}$ & $\begin{array}{c}1360 \\
47.72 \%\end{array}$ & $\begin{array}{c}316 \\
54.02\end{array}$ & $\begin{array}{l}1676 \\
48.79\end{array}$ & $\begin{array}{c}41 \\
55.40\end{array}$ & $\begin{array}{c}28 \\
73.68\end{array}$ & $\begin{array}{c}69 \\
61.61\end{array}$ & $\begin{array}{c}7 \\
53.85\end{array}$ & $\begin{array}{c}47 \\
55.95\end{array}$ & $\begin{array}{c}54 \\
55.95\end{array}$ & $\begin{array}{c}6 \\
54.55\end{array}$ & $\begin{array}{c}1805 \\
49.38 \%\end{array}$ \\
\hline $\begin{array}{l}\text { Número total de } \\
\text { mujeres y \% }\end{array}$ & $\begin{array}{c}1490 \\
52.29 \%\end{array}$ & $\begin{array}{c}269 \\
45.98\end{array}$ & $\begin{array}{l}1759 \\
51.20\end{array}$ & $\begin{array}{l}334 \\
4.59\end{array}$ & $\begin{array}{c}10 \\
26.32\end{array}$ & $\begin{array}{c}43 \\
38.39\end{array}$ & $\begin{array}{c}6 \\
46.15\end{array}$ & $\begin{array}{c}77 \\
44.05\end{array}$ & $\begin{array}{c}43 \\
44.33\end{array}$ & $\begin{array}{c}5 \\
45.55\end{array}$ & $\begin{array}{l}1850^{* * * *} \\
50.62 \%\end{array}$ \\
\hline
\end{tabular}

Cuadro 2. Población total del partido de Atacama en 1787; relación con el número de tributarios y proporción de hombres y mujeres. *: EI original suma 156, lo que sería un error si las cifras de San Pedro y Chiu Chiu son correctas; **: E1 original suma 3658 debido a que se agregan por error tres mujeres casadas a la suma respectiva; ***: E1 original suma 1859 y 1853 . Ambas sumas son erróneas, la última debido a la suma equivocada de las viudas originarias, la primera parece ser sólo un error de anotación.

La relación entre el total de los tributarios y la población total resulta ser 5.01. En anteriores trabajos hemos discutido las ventajas e inconvenientes de utilizar el dígito 5 como multiplicador del número de tributarios y obtener de este modo la población total (Hidalgo 1972a, 1972b). A título de comparación podemos anotar que esta relación en 1773, en Tiwanaku, era del orden de 4.26 (Ponce 1975: 19), pero en 1562, en Huánuco, el número de casados y amancebados en relación a la población total parece haber sido 6.32 (Hadden 1967: 372). ${ }^{15}$

Si se compara ahora esta relación en detalle por cada grupo de población tributaria se puede apreciar una cifra decreciente; desde los originarios con 5.08 a los cholos con tierras con $4.14 \mathrm{y}$ forasteros sin tierras con

15 Smith (1970) proporciona otros datos tempranos en base a relaciones geográficas y la discusión de los datos de Huánuco. No obstante, la información para hacer comparaciones válidas sigue siendo escasa, dispersa y poco usable. En este campo como en otros hace falta más investigación.
3.88. Esta tendencia se detiene en la cifra aberrante de los cholos sin tierras, 11, pero en este caso, como sabemos, ese resultado se debe a la existencia de un solo tributario registrado. Al considerar a los cholos sin tierras ausentes la cifra sería de 2.75 . Se puede observar además, en este caso, que habiendo un solo tributario existen tres mujeres casadas, y ausencia de niños y solteras. Se podría deducir que estamos frente a un grupo en disolución.

Otro dato significativo es la relación porcentual de hombres y mujeres. Las cifras de conjunto son cercanas, 1805 hombres y 1850 mujeres, un $49.38 \%$ y un $50.62 \%$, respectivamente, pero en el detalle se producen desviaciones que son indicativas de la estructura interna de las categorías de población. Empecemos por los originarios. No causa inquietud en el caso de San Pedro, que el número de mujeres se remonte a $52.29 \%$, pero en cambio el $54.02 \%$ de varones en Chiu Chiu resulta sorprendente; tal situación, ¿se debería a un porcentaje mayor de forasteros con tierras, asimilados dentro de la categoría de originarios en esta revisita? 
Los porcentajes de cholos varones con tierras son $55.40 \%$ y $73.68 \%$ en San Pedro y Chiu Chiu, respectivamente. Obviamente más que la relación tributarios-población total, estas cifras están expresando la imposibilidad de un alto porcentaje de hombres para establecer sociedades conyugales con mujeres de su grupo. Esto indicaría a su vez estructuras nucleares débiles si se considera la tendencia a la endogamia descrita 100 años más tarde por Bowman. Cosa parecida puede decirse de los forasteros sin tierras y de los cholos sin tierras. ${ }^{16}$

\section{Datos del movimiento demográfico}

Ahora que conocemos inicialmente las características de la población tributaria, procuraremos construir una curva que exprese el movimiento de la población y nos permita descubrir nuevos rasgos de los documentos transcritos como de la sociedad atacameña de la segunda mitad del siglo XVIII. Veamos de qué datos disponemos:

Los visitadores de 1787 dicen al Dr. Juan del Pino Manrique, Intendente de Potosí, que han concluido la visita "con su aumento de 81 indios, que quedan efectivos en la clase de tributarios sobre el número de 648, ya que lo contribuían desde el año de setecientos setenta y siete, que fue cuando se practicó la última matrícula de este partido" (Mf24r). Otro documento agrega: "El aumento resultado por ella es de ochenta y un indios, cuyo tributo asciende a setecientos ochenta y tres pesos" (Mf29r).

El "Informe de la Contaduría de Retasas sobre la Revisita del Partido de Atacama" (1787) afirma que se:

"concluyó numerando en todo el 729, tributarios útiles los 703 originarios de tasa de 10 pesos y los 26 restantes forasteros sin tierras de la de 7 pesos, entre los cuales hay 27 cholos de la primera clase y uno de la segunda, que están en costumbre de tributar que todos han de contribuir anualmente
7212 pesos y habiéndose empadronado en la última anterior Revisita practicada el año de 1752, 491, tributarios los 475, originarios, y 16 forasteros cuía gruesa ascendía a 4862 pesos resulta el aumento de 283 contribuyentes, y la ventaja a favor del ramo de tributos de 2350 pesos en cada año” (Mf3 Ir).

Verifiquemos esta información:

1) "El año de 1752,491 , tributarios los 475 , originarios y 16 forasteros", o sea 475 tributarios con tierras de tasa de $\$ 10=\$ 4750$, y 16 tributarios sin tierras de tasa de $\$ 7=112.4862$ cifra coincidente con la del texto.

2) 1777. "Con aumento de 81 indios, que quedan efectivos en la clase de tributarios sobre el número de 648, que ya le contribuían desde el año de setecientos setenta y siete". O sea, $648+81=729=$ número de tributarios de 1787. No conocemos la composición de la población de 1777 en lo que se refiere a su distribución entre tributarios con tierras y sin tierras. Pero si analizamos la cantidad en que aumenta el tributo entre las dos visitas, concluimos que era pagada por 72 tributarios con tierras y nueve tributarios que pagaban $\$ 7$ anuales. El porcentaje de tributarios sin tierra, como se puede suponer, fue permanentemente bajo: en 1752 constituyó el $3.26 \%$ del total, en 1787 un $3.57 \%$, en 1792 el $5.78 \%$ y en 1804 el $5.07 \%$.

3) 1787. "729, tributarios útiles los 703 originarios de tasa de 10 pesos y los 26 restantes forasteros sin tierras de la de 7 pesos, entre los cuales hay 27 cholos de la primera clase y uno de la segunda".

Si comparamos con las categorías que hemos visto en el Cuadro 2 podemos ver cómo los funcionarios de la Contaduría de Retasas califican a los tributarios de 1787:
729 tributarios: a) Originarios

b) Cholos con tierras

c) Forasteros sin tierras

d) Cholos sin tierras

Total de tributarios
676

27

25

1

703 tributarios útiles de tasa de 10 pesos.

26 forasteros sin tierras de 7 pesos de tasa.

729

16 Es posible, mediante los datos de la Revisita de 1804, intentar hacer pirámides de edades de la población tributaria; es un tema que queda pendiente. 
4) 1792. Para las cifras de tributarios de este año nos remitimos al extracto de la visita correspondiente:

\begin{tabular}{|c|c|c|c|c|}
\hline Repartimientos & San Pedro & Chiu Chiu & Total & \\
\hline \multirow{4}{*}{$\begin{array}{l}\text { Originarios } \\
\text { Cholos con tierras } \\
\text { Forasteros }\end{array}$} & 333 & 118 & 451 & \\
\hline & 10 & 12 & 22 & 473 Trib. c/t \\
\hline & 3 & 26 & 29 & Sin tierras \\
\hline & 346 & 156 & 502 & Total \\
\hline
\end{tabular}

5) 1804. De acuerdo con el extracto de la visita:

\begin{tabular}{|c|c|c|c|c|}
\hline Repartimientos & San Pedro & Chiu Chiu & Total & \\
\hline \multirow[t]{2}{*}{$\begin{array}{l}\text { Originarios y forasteros con tierras } \\
\text { Cholos con tierras } \\
\text { Forasteros sin tierra }\end{array}$} & $\begin{array}{r}398 \\
9 \\
5\end{array}$ & $\begin{array}{r}106 \\
11 \\
28\end{array}$ & $\begin{array}{r}504 \\
20 \\
33\end{array}$ & $\begin{array}{l}524 \text { Trib. c/t } \\
\text { Sin tierras }\end{array}$ \\
\hline & 412 & 145 & 557 & Total \\
\hline
\end{tabular}

Ahora podemos anotar la evolución que sufre la cantidad de tributarios Atacameños entre 1752 y 1804.
Para calcular la población total utilizaremos la cifra que resulta de los datos de 1787 (Cuadro 3):

\begin{tabular}{|c|c|c|c|c|c|}
\hline Visitas & \multicolumn{3}{|c|}{ Tributarios $\times 5=$ población total } & $\%$ de incremento en el per. & $\%$ de incremento anual \\
\hline 1752 & 491 & & 2455 & & \\
\hline 1777 & 648 & & 3240 & +31.98 & +1.28 \\
\hline 1787 & 729 & $\begin{array}{l}\text { (En este caso tenemos el dato de la } \\
\text { población total) }\end{array}$ & 3655 & +12.81 & +1.28 \\
\hline 1792 & 502 & & 2510 & -31.33 & -6.27 \\
\hline 1804 & 557 & & 2785 & +10.96 & +0.91 \\
\hline
\end{tabular}

Cuadro 3. Movimiento demográfico de los curatos de San Pedro y Chiu Chiu (1752-1804).

En relación a los años límites, 1752 y 1804, el crecimiento supuesto de la población es de $13.44 \%$, o sea, $0.26 \%$ anual. Sin embargo, al analizar el Gráfico 1 o revisar los porcentajes vemos que este crecimiento ha tenido diferentes ritmos a lo largo de estos 52 años, entre 1752 y 1787, es decir, durante 35 años el ritmo de crecimiento anual fue de $+1.28 \%$, pero en los cinco años que median entre 1787 y 1792 la población tributaria de Atacama desciende aparentemente en 227 individuos equivalente a un promedio de $6.27 \%$ anual de crecimiento negativo, tendiendo a recuperarse al lento ritmo de $+0.91 \%$ en los 12 años siguientes. Para apreciar el diferente comportamiento de la población atacameña podemos verificar cuál fue el crecimiento de los repartimientos de Chiu Chiu y San Pedro a través de los datos de las visitas de 1787, 1792 y 1804 (Gráfico 2).

Como puede verse, en 1792 la población de San Pedro ha decrecido en 241 personas, o sea $-47.71 \%$, mientras que la del curato de Chiu Chiu ha crecido en 14 tributarios, o sea $+9.86 \%$. En 1804, Atacama la Alta aumenta en $+19.08 \%$, pero Atacama la Baja disminuye su población de tributarios en $7.05 \%$ (Cuadro 4).

¿Qué explicaciones puede tener este extraño comportamiento demográfico? Creo que debemos analizar tres posibilidades: 1) epidemias; 2) migraciones; $y$ 3) variaciones diferenciales en la forma de censar la población tributaria debido a la negativa de las autoridades europeas de aceptar la "verticalidad". Estas variaciones en 1792 habrían afectado a Atacama la Alta y no a la Baja.

1) Epidemias. Un indicador indirecto de epidemias lo constituyen los registros parroquiales de defunciones, si bien, como anota el profesor Casassas, los libros parroquiales nos han llegado "con apreciables deterioros e incompletos; con muchos vacíos cronológicos" 


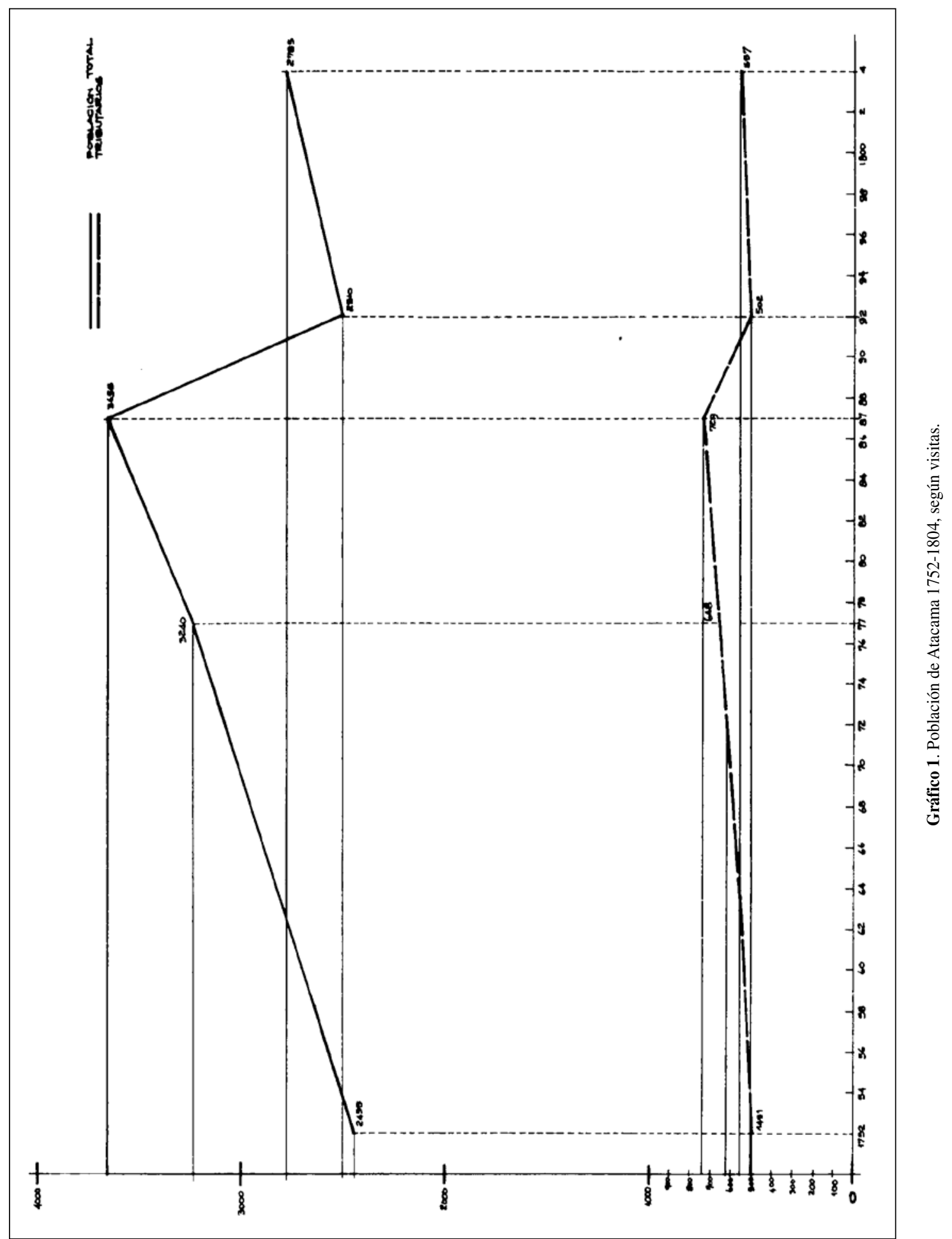


CURETO DE DTACANA LA MUA

CURATO DE ATACAMA L

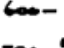

$500-587$

$36-$

sao-

sis-

$500-$

$400-$

$460-$

$40-$

$400-$

$400-$

300

so-

340-

300-

$\infty 0-$

$200-$

260-

240-

200-

-

-

$160-$

$40-$

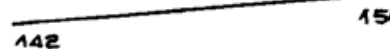

156

(1)

en

$60-$

do -

2o-

$0-$

1787

1792

1804

Gráfico 2. Tributarios de San Pedro y Chiu Chiu según las revisitas de 1787-1792 y 1804.

\begin{tabular}{|c|c|c|c|c|c|c|c|c|c|c|c|c|c|c|c|}
\hline & \multicolumn{5}{|c|}{1787} & \multicolumn{4}{|c|}{1792} & \multicolumn{5}{|c|}{1804} & \multirow[b]{2}{*}{ 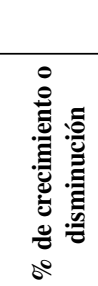 } \\
\hline ○ & & 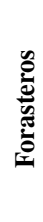 & $\begin{array}{l}\frac{5}{0} \\
\frac{0}{e} \\
\frac{0}{0}\end{array}$ & 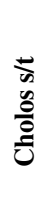 & Total & 泀 & 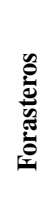 & 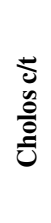 & Total & 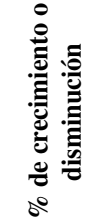 & & 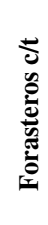 & $\frac{\ddot{0}}{\frac{8}{0}}$ & Total & \\
\hline San Pedro & 568 & 4 & 14 & 1 & 587 & 333 & 3 & 10 & 346 & $-47.71 \%$ & 398 & 5 & 9 & 412 & $+19.08 \%$ \\
\hline Chiu Chiu & 108 & 21 & 13 & & 142 & 118 & 26 & 12 & 156 & $+9.86 \%$ & 106 & 28 & 11 & 145 & $-7.05 \%$ \\
\hline
\end{tabular}

Cuadro 4. Movimiento demográfico de los curatos de San Pedro y Chiu Chiu (1787, 1792 y 1804). 
o, inclusive, "durante ciertos lapsos no se anotaron las inscripciones que hubieran correspondido", en lo que contribuyen:

"los viajes del párroco, en algunas ocasiones, al arzobispado de La Plata, para cumplir los trámites de visita, para atender a los quebrantos de su salud a sus gestiones personales, o bien (con mayor incidencia probablemente) sus más o menos frecuentes desplazamientos desde el pueblo matriz o iglesia parroquial a los poblados anexos. Claro está que, en muchas oportunidades, se aprecia en los libros parroquiales un efectivo y acumulado registro de inscripciones sacramentales (bautizos, matrimonios, exequias funerarias) correspondientes a actas o hechos sucedidos en un lugar determinado durante las ausencias del sacerdote (nacimiento, iniciación de la vida marital, defunciones), pero resulta evidente, a través del examen cuidadoso de los libros, que muchos de tales acontecimientos, en diversas ocasiones, quedaron sin registro ni anotación" (Casassas 1974b: 75-76).

En relación a epidemias, Casassas registra una que afectó a Cobija en 1713. No se sabe, debido a las hojas perdidas del registro, si esa "peste aguda de virguelas y mal grabe" afectó el interior atacameño. Sin embargo, a pesar de la ausencia de otras menciones expresas, en base al número de defunciones registradas, Casassas sospecha la presencia de epidemias en San Pedro y sus anexos en los años 1706, 1715, $1747,1750,1765,1773$ y 1788 . Lo mismo dice de Chiu Chiu y sus anexos para los años 1764, 1765, 1775, 1777, 1783 y 1797 (Casassas 1974b: 88).

Para nuestros efectos presentaremos los datos parroquiales de Casassas relativos a defunciones desde 1775 a 1895 para apreciar de qué manera estas noticias pueden contribuir a explicar las variaciones de población que registran las visitas de 1777 a 1792 (Cuadro 5).

El lapso más significativo para nuestro propósito es el que va de 1787 a 1792 en San Pedro, dado que en estos años la población de Chiu Chiu y sus anexos no decrece y no presenta una situación aparentemente anómala. Ahora bien, el número de defunciones para estos años en el Curato de San Pedro no alcanza los niveles que indican las revisitas, incluso el número de 46 muertes para 1788, si bien alto en relación a los tres años anteriores, no es tan expresivo como los 148 de 1777, a los 96 de 1775, inclusive los 275 que fallecen en 1765. Pudiera ser, por otra parte, que el número de fallecidos fuese más alto en 1789, 1790 y 1791 de lo que indica el cuadro, ya que es muy poco probable que no se registrara ni una sola muerte durante todo un año como se anota en $1789 .{ }^{17}$

Pero, en todo caso, carecemos de evidencias que indiquen una epidemia de la magnitud suficiente como para explicar el descenso de 241 tributarios de San Pedro entre 1787 y 1792, por lo tanto, nos parece necesario recurrir a otro tipo de hipótesis para explicar este hecho.

2) Migraciones. Obviamente, así como es difícil encontrar suficiente información en las noticias relativas a defunciones, es menos probable demostrar una migración del orden del $31.14 \%$ del total de adultos en edad de trabajar o mejor del $47.71 \%$ del Curato de San Pedro, a menos que existiera una fuerte compulsión. Aun cuando carecemos de una información detallada relativa al Partido de Atacama, nos atreveríamos a asegurar que entre 1787 y 1792 no existió ningún hecho de tal relevancia que provocara una reacción de esa magnitud. ${ }^{18}$

3) Una hipótesis adicional: La "verticalidad". Cabe la posibilidad, y quizás pueda ser demostrado documentalmente, que el método de encuesta de la población tributaria o, más bien, el concepto de lo que era un tributario atacameño, sufriera importantes modificaciones.

Nuestra hipótesis supone que la población de Atacama tenía, al igual que otros grupos andinos, un sistema de poblamiento disperso (Mayer 1792: 345), probablemente similar al conocido como "control vertical de un máximo de pisos ecológicos” (Murra 1972), las islas

17 Juan van Kessel me ha hecho notar, en base al cálculo de los promedios o esperanza de vida que se obtienen del número promedio de defunciones anuales (excluyendo los años de 1789-1790-1791 para evitar distorsiones) divididas por los totales de población de 1787 y 1792 cuyos resultados son 60.4 y 35.6 respectivamente, que estas cifras resultan demasiado altas en relación a otras obtenidas para Tarapacá, cuyo promedio es aproximadamente 20 años de esperanza de vida (ver Podestá 1975). De esto se desprende que existe un elevado porcentaje de defunciones no registradas si suponemos que los promedios de vida deben haber sido similares en las diferentes unidades geográficas de la época. Aquí pueden incidir, además, a nuestro juicio, las distorsiones de la "verticalidad" sobre los cálculos demográficos.

18 Hemos revisado cuidadosamente la documentación del ANB, de modo que estamos seguros que, de haber existido un acontecimiento de ese orden, habría quedado un testimonio escrito. 


\begin{tabular}{|c|c|c|c|c|c|c|c|}
\hline \multirow{2}{*}{ Años } & \multicolumn{3}{|c|}{ San Pedro } & \multicolumn{3}{|c|}{ Chiu Chiu } & \multirow{2}{*}{ Total } \\
\hline & Hombres & Mujeres & Subtotal & Hombres & Mujeres & Subtotal & \\
\hline 1775 & 49 & 47 & 96 & 15 & 11 & 26 & 122 \\
\hline 1776 & 19 & 17 & 36 & 7 & 5 & 12 & 48 \\
\hline 1777 & 65 & 83 & 148 & 7 & 0 & 7 & 155 \\
\hline 1778 & 30 & 23 & 53 & 7 & 13 & 20 & 73 \\
\hline 1779 & 20 & 15 & 35 & 9 & 9 & 18 & 53 \\
\hline 1780 & 12 & 16 & 28 & 6 & 7 & 13 & 41 \\
\hline 1781 & 22 & 26 & 48 & 10 & 16 & 26 & 74 \\
\hline 1782 & 18 & 23 & 41 & 7 & 3 & 10 & 51 \\
\hline 1783 & 25 & 41 & 66 & 4 & 5 & 9 & 75 \\
\hline 1784 & 22 & 21 & 43 & 3 & 8 & 11 & 54 \\
\hline 1785 & 8 & 28 & 36 & 5 & 9 & 14 & 50 \\
\hline 1786 & 18 & 13 & 31 & 9 & 3 & 12 & 43 \\
\hline 1787 & 11 & 13 & 24 & 5 & 9 & 14 & 38 \\
\hline 1788 & 25 & 21 & 46 & 37 & 41 & 78 & 124 \\
\hline 1789 & 0 & 0 & 0 & 26 & 21 & 47 & 47 \\
\hline 1790 & 4 & 5 & 9 & 11 & 7 & 18 & 27 \\
\hline 1791 & 10 & 0 & 10 & 26 & 21 & 47 & 57 \\
\hline 1792 & 30 & 19 & 49 & 9 & 14 & 23 & 72 \\
\hline 1793 & 31 & 14 & 45 & 6 & 10 & 16 & 61 \\
\hline 1794 & 23 & 19 & 42 & 11 & 6 & 17 & 59 \\
\hline 1795 & 22 & 25 & 47 & 18 & 15 & 33 & 80 \\
\hline 1796 & 22 & 30 & 52 & 11 & 10 & 21 & 73 \\
\hline 1797 & 33 & 36 & 69 & 10 & 5 & 15 & 84 \\
\hline 1798 & 16 & 15 & 31 & 6 & 12 & 18 & 49 \\
\hline 1799 & 18 & 17 & 35 & 13 & 11 & 24 & 59 \\
\hline 1800 & 18 & 20 & 38 & 11 & 8 & 19 & 57 \\
\hline
\end{tabular}

Cuadro 5. Defunciones en San Pedro de Atacama y Chiu Chiu (1775-1895).

atacameñas se ubicaban en el Noroeste Argentino. Es decir, había población originaria de Atacama que tenía tierras en Salta y en Tucumán, que no había perdido sus derechos en sus lugares de origen, seguían reconociendo como sus jefes a los caciques atacameños, a los cuales en señal de acatamiento pagaban tributos. Esta situación habría cambiado para Atacama la Alta después de la visita de 1787, y antes de la visita de 1792 , en la cual se registra la baja que contribuye a explicar el descenso de los 241 tributarios.

Intentaremos probar esta hipótesis

El 23 de febrero de 1787, José Agustín de Arce y Pedro Manuel Rubin de Celis en su informe al Dr.
Juan del Pino Manrique, Intendente de Potosí, justifican el tiempo empleado en la Revisita de Atacama del siguiente modo:

"En medio que han sido eficaces nuestro deseo y empeño de concluir anticipadamente la Revisita de los Indios y demás castas que hay en este Partido sujetos a tributos, ha sido imposible en menos de los cuatro meses, que hemos empleado en su actuación, a causa de que muchos del repartimiento de San Pedro de Atacama viven radicados de inmemorial tiempo en diferentes lugares de la jurisdicción del Tucumán y tan distantes de los de su origen que les ha sido indispensables la demora para venir hasta ellos a ser empadronados como era regular (...)” (Mf24r). 
Agregan los mismos funcionarios que: "Debe estimarse proporcionado el aumento que resulta de la Revisita", 81 tributarios, "atendida la corta entidad de su entero, los muchos que resultan sin saverse de ellos, y sobre todo, que por ser sumamente extériles las tierras que disfrutan en sus repartimientos, viven separados los más en las distancias, por que no es fácil reducirlos a la sugeción que sólo puede evitar el mayor extravío". Estas mismas circunstancias hicieron que los caciques no pudieran efectuar los tercios cada cuatro meses, sino sólo semestralmente, y esto:

“(...) no pueden aún cumplirlo... especialmente de aquellos que viven en la jurisdicción de la Intendencia de Salta, hasta donde con los mayores trabajos y no pocas espensas tienen que conducirse y en muchos casos con riesgo de perder la vida en el tránsito de la cordillera que tienen que andar por término de ocho días, y a este tenor es tan penosa la cobranza que toda ipérbole es corta para significar los atrazos (...)” (Mf25r/26r).

"Con el mismo objeto de asegurar la cobranza de tributos por lo respectivo a los indios que viven en la jurisdicción del Tucumán se ha tenido por combeniente nombrar en los pueblos de Toconao, Soncor. Peyne y Socaipe en cada uno o cobradores, y en el primero tres y un segundo mediante a que no de otro modo, puede lograrse el todo de la recaudación por la suma distancia que los separa de los diferentes lugares de su residencia (...)” (Mf27r).

Tal era la situación de acuerdo a las fuentes que provienen de Atacama, ahora disponemos del extracto de un documento encontrado por Murra en el Archivo de Buenos Aires y publicado en Estudios Atacameños 3 (Serracino 1975). Creemos que este documento está íntimamente ligado al desglose de la población atacameña que tributaba desde el Noroeste Argentino a su lugar de origen, sin lugar a dudas, la publicación de este documento completo sería de gran interés. Por el momento nos restringiremos a reproducir los párrafos que nos parecen más significativos:

"Doctor don Vicente Anastacio de Isasmendi... de Calchaqui de muchos años a esta parte residen en aquella mi doctrina, indios que tributan a la provincia de Atacama lo más de ellos nativos en aquel distrito y descendientes de los que se trasladaron sujetos enteramente en lo espiritual a la citada mi doctrina."

Salta, 9-IV-1791 "f. $3 v$. que empadrone a los indios de la Provincia de Atacama capaces de tributar (...).

\section{“20-IV}

"F. 4r. que todo el sínodo salga del mismo tributo que el indio paga se presenta la dificultad de si los de Atacama establecidos en Calchaqui han de contribuir el suio en esta jurisdicción o en la de su Provincia sobre que haremos las siguientes reflexiones. Haga un solo separado padrón que los distinga de todos los demás de aquel curato (...)”.

De estos párrafos se desprende el interés de las autoridades calchaquíes por abordar el tema que nos preocupa particularmente en el caso de los eclesiásticos, quienes teniendo enteramente sujetos en lo espiritual a los originarios de Atacama no reciben el sínodo que les correspondería del tributo de estos indígenas.

El expediente continúa.

Veamos ahora los argumentos que se esgrimen para transformar esta situación cuyos orígenes temporales no conocen sus actores:

"F. 4r. (...) aunque en Atacama los indios indicados corren con el nombre de originarios por que allí tienen tierras propias ya en Calchaqui deven apreciarse como foráneos (...)”.

Destaca la distancia de 200 leguas entre Atacama y Salta "la mayor parte despoblados y cordilleras" que los "miserables caciques"... "en cada tercio se ven en la precisión de viajar con las inclemencias, trabajos y crueles hambres y ofrecer aquellos desiertos y el corto viático que para este fin se les tiene asignados (...)".

La información de Salta, según el extracto publicado por Serracino (1975), sigue con la recomendación de que se extienda la investigación a otros puntos de la jurisdicción de Salta y que, además, se verifique el padrón pasado 1787 (?) con otro nuevo para determinar el "número cierto de los residentes en Atacama y en la jurisdicción de Salta", debido a que desde la última revisita "se han ido trasladando continuamente y en crecido número".

El expediente continúa con documentos fechados el año 1791 en Potosí y en San Pedro de Atacama. En este último pueblo hacia fines de ese año se hace 
comparecer a los caciques de los diferentes ayllu para que informen del número de tributarios que residen en la intendencia de Salta.

El "segundo de gobernador" del ayllu de Condeduque identificó a 15 tributarios indicando nombre, edad y lugar de residencia en el Noroeste Argentino.

Del ayllu de Sequitor declara su cacique del mismo modo cuatro tributarios y así lo hacen los caciques de los siguientes ayllu:

Ayllu de Coyo $=$ declara a 15
Ayllu de Betere $=$ declara a 13
Ayllu de Solor $=$ declara a 15

Ayllu de Solcor "muy similar no lo reproduzco /J.V.M./ se habla de otras 5 parcialidades, con otro cacique: Tocorado, Socor, Socaire, Peyne, Lusquis /J.V.M.”. El último párrafo del extracto de Murra, es de interés para nosotros:

"F 56r. 271 personas de origen de Atacama, 79 tributarios, y en Catamarca 175 personas 42 tributarios."

Si no entiendo mal, esto significaría que se detectaron 79 tributarios en Salta y 42 en Catamarca de origen atacameño, son en total 121 tributarios; no sabemos si se trata del total de atacameños residentes en el Noroeste Argentino o sólo aquellos que residen en los puntos mencionados. Debemos destacar que los resultados indican que estos 121 tributarios son de Atacama la Alta y no de la Baja. Estamos frente a guarismos lo suficientemente significativos como para suponer que su exclusión en el empadronamiento de 1792 contribuyó fuertemente a explicar el bajo número de tributarios que registra esa revisita.

Ciento veintiún tributarios representa, en 1787 $20.61 \%$ de los tributarios del Repartimiento de San Pedro de Atacama. Estas cifras estarían indicando que el porcentaje de atacameños que vivían permanentemente fuera de su territorio fluctuaría entre este $20 \%$ como cifra mínima y $47.79 \%$ como rango máximo.

¿De qué modo hacían efectivo su tributo los atacameños del Noroeste Argentino? De acuerdo a las fuentes aquí publicadas, pagaban no mediante monedas, sino en productos equivalentes en dinero a la tasa de tributo, los que eran convertidos en dinero por el cacique que actuaba como un agente financiero.
"Aunque todos o la mayor parte de los tributarios pagan su respectiva asignación en frutos de labranza, o en otras especies de Industria, tienen acentado con los cobradores el equivalente precio o su estimación, y así nunca quedan perjudicados, y más bien los caciques sufren algún atraso en la demora, que suelen padecer en darles expendio para cubrirse del dinero que anticipan regularmente en muchos casos, y especialmente por aquellos que no tienen mayor posible, y sobre este supuesto no hay entre ellos la discordia que podía motivar otra mala versación" (Mf27r).

La variedad de productos con los que pagaban su tributo, probablemente pueda ser determinada en el futuro, interesan particularmente los antecedentes prehispánicos que pueden entregar los arqueólogos y las futuras investigaciones etnohistóricas. Señala Bowman (1942: 242) que los valles del noroeste "se adaptan, en una amplia escala, al cultivo de productos tropicales, subtropicales y de la zona templada", de tal modo que la variedad de productos puede ser muy grande y puede haber variado significativamente en el tiempo.

Testimonios del siglo XVIII y posteriores relativos a verticalidad y trashumancia

La presencia de este poblamiento disperso fue descrita en el siglo XVIII y con posterioridad, pero se atribuyó a distintas circunstancias de acuerdo a los problemas que tenía en vista el observador. Don Juan del Pino Manrique, en su Descripción de la Villa de Potosí y de los partidos sujetos a su Intendencia (1787), sostiene que el Partido de Atacama:

“(...) tiene dos curatos, el uno nombrado San Pedro de Atacama, dista 160 leguas de esta capital con cinco anexos, que son San Lucas de Toconao, Santiago de Socaire, San Roque de Peyne, Susquis e Incaguas. Este es un mineral de oro hoy arruinado, aunque de nombre en lo antiguo. De temperamento frío y escaso de todos comestibles, de que le proveen los inmediatos valles del Tucumán. El de los anexos de Socaire y Sus-quis es igualmente destemplado, por su situación inmediata a la Cordillera de Chile, y cuya causa hace también que estén casi despoblados, viviendo los indios originarios de ellos en la jurisdicción del Tucumán por la mayor facilidad con que consiguen su subsistencia. Aunque el temperamento del anexo de Peyne es más benigno por la mayor cercanía a la costa, se halla también casi despoblado porque sus proporciones productivas no sufren residencia fija” (cit. en Bertrand 1885: 143). 
En 1787 el doctor don Pedro Vicente Cañete afirma en un sugerente párrafo:

"El único modo de que floresca este país San Pedro es formar, en la quebrada donde tiene su origen el manantial, una laguna que recoja las aguas de avenidas a su tiempo; engrosándose entonces tres o cuatro tantos más el caudal actual del estero, podrá surtir agua para regar 12 o más leguas de terreno en las ocasiones de mayor necesidad, cesarán las pendencias que riñen de continuo los ayllos entre sí por el repartimiento de aguas, habrá muchas más tierras que distribuir a los que en el día no las cultivan por falta de ellas, asegurándoles con el interés de la labranza para que no deserten al Tucumán o a otros países más dichosos (como ahora lo hacen) con perjuicio del ramo de tributos" (Cañete 1952 [1797]: 427-428).

Los datos de viajeros del siglo XIX que contienen valiosas referencias al tema que tratamos serán dados a conocer en publicaciones futuras por Serracino (com. pers.) quien los está trabajando.

En las primeras décadas de este siglo Bowman (1942: 289) describe a San Pedro de Atacama como "una ciudad de arrieros", que "actúa como centro de distribución del ganado que se lleva a las salitreras, las minas dispersas y a los establecimientos situados sobre la línea del ferrocarril" (1942: 282). Destaca la importancia del agua para la actividad agrícola en estos "oasis" como de los pastos para la actividad ganadera, cuya presencia o ausencia generan un poblamiento disperso con uso simultáneo por una familia de diferentes pisos o nichos ecológicos, en patrones que oscilan entre los conceptos de verticalidad (Murra 1972) y trashumancia (Aranda 1971; Ampuero e Hidalgo 1975; Le Paige 1975; Lynch 1975a, 1975b; Núñez 1975; Núñez et al. 1975; Schiappacasse y Niemeyer 1975; Serracino 1975; Serracino y Stehberg 1975). Veamos algunos párrafos:

"A lo largo de la línea de cada valle se suceden las parcelas dispersas de la preciosa tierra irrigada. Entre ellas puede haber trechos sólo cubiertos de grava en la planicie del valle (...). Cada trecho o aldea representa alguna ventaja natural.

Aquí un grupo de arboles de algarrobos se alimenta con el agua del subsuelo y proporciona abundantes frutos de algarrobo. Allá un grupo de árboles de chañar proporciona nueces para el delicioso manjar de chañar. En el borde del pantano de Tevinguicha hay pasto que se alquila a los conductores de ganado que cruzan la cordillera. El suelo es arenoso en Cucuter, pero no tiene sales nocivas y si se riega dos veces al año produce buenas cosechas. En Catarpe hay terrazas abrigadas fáciles de regar y en consecuencia se ven hermosas huertas" (Bowman 1942: 287-289).

Después de esta descripción de la variedad que ofrece el territorio, Bowman agrega datos sobre la economía y los sistemas de poblamiento; señala que San Pedro de Atacama, a diferencia de otros pueblos vecinos, necesita recursos exteriores para sostener la población adicional que posee. Esto daba origen a su vez a un intercambio entre los diferentes tipos de productores del área dependiente de este pueblo:

"Desde sus casas en el valle y los pastizales de las alturas, vienen los pastores en busca de provisiones: chuño (papa helada y seca), chañar, frutas secas, trigo y harina. Su dependencia del pueblo es tan grande que en muchos casos construyen dos chozas: una, que es el hogar del oasis, en una quebrada a algunas millas de distancia y la otra, en el desierto, al borde de los huertos que rodean San Pedro. Hacen pastar sus rebaños en los pastizales y arbustos que crecen en las afueras de la población, descansan unos días, comercian y luego regresan. Algunos han llegado a construir una tercera choza en algún trecho abandonado de la tierra, en las márgenes comunes del desierto y de la tierra irrigada, y alli plantan unos pocos granos y semillas que aumentan sus insuficientes recursos" (1942: 289-290).

El mismo autor aclara que esta situación no es exclusiva de los sectores vinculados a San Pedro, sino que era mucho más general, así, por ejemplo, de Toconao dice:

"Dos leguas al norte de ese pueblo, hay una quebrada llamada Zapar, en donde los terratenientes de Toconao cultivan todas las simientes que pueden. Cerca y lejos, aún en posiciones más elevadas, muchos sitios que tiene cada uno su nombre particular, son visitadas al tiempo de la siembra y de la cosecha. Tributarios de Toconao son otras tres pequeñas áreas sembradas: Jeri, Atite y Laccira" (1942: 292).

Destaca Bowman que por su situación austral los pastos de alturas no pueden ser aprovechados todo el año por los pastores. Durante el invierno son 
expulsados por el frío a sitios más bajos, donde deben buscar retazos de pastos en sitios abandonados cuando el oasis está saturado. Esto crea una migración estacional, sin que puedan descubrirse conflictos entre los pastores y los agricultores del desierto. Por el contrario, uno y otro, según Bowman, están en una situación de mutua dependencia y deben complementarse. Y agrega:

"En realidad esta relación suplementaria va tan lejos en el caso de los oasis más pequeños, que éstos son simples invernaderos para los pastores de la monta$\tilde{n} a$, quienes tienen sus propias huertas que dejan al cuidado de los viejos e inválidos durante la mayor parte del año. En Tilo-monte se siembran unas pocas parcelas de tierra y se las deja luego al cuidado del viento y del sol hasta el tiempo de la cosecha. Casi toda la población de Soncor y de Socaire están durante el verano en las montañas y sólo permanecen unas cuantas personas ancianas y débiles que deben cuidar las huertas" (1942: 293).

De acuerdo, entonces, a lo que este autor sostiene, pastores y agricultores no serían unidades familiares distintas en un buen número de casos; por el contrario, parece ser que la especialización de una sola familia sería la excepción. Así lo confirma Bowman en su misma obra comparando esta situación con otras:

"A diferencia de los pastores del Perú y de Bolivia que hacen pastar sus rebaños durante todo el año en las mayores elevaciones, porque son capaces de soportar las pocas semanas de frío en lo más fuerte de la estación invernal, la mayoría de los pastores de la Puna de Atacama se ven arrojados de ella durante una estación íntegra. Sería imposible para ellos vivir todo el año en muchos de sus campamentos de la alta faja montañosa. Cuando bajan a los valles, vienen no como vagabundos, sino como propietarios, con derechos; en otro lugar su sistema migratorio sería imposible. Según la costumbre, dejan a una parte de la familia, compuesta principalmente de muchachos y mujeres ancianas, en los parajes más bajos para vigilar sus propiedades y especialmente para cuidar los campos y sus limitados sembríos, mientras ellos conducen rebaños a los altos pastizales. Cuando llegan los fríos del invierno, los pastores regresan de sus pequeños corrales encaramados en las laderas de la montaña y descienden a los valles más bajos, en donde sus rebaños, que ya han engordado, se mantienen con los escasos herbajes del valle y los tallos secos de los pastos del desierto" (Bowman 1942: 349-351).
Mostny y colaboradores (1934) sostienen que por su situación de latitud y altura Peine participa de las lluvias de verano y de fuertes oscilaciones de temperatura entre el día y la noche, diferencias que pueden alcanzar $30^{\circ}$ y más:

"La temperatura nocturna, que también en los meses de mayor calor está cerca de $0^{\circ}$, elimina de antemano cierta clase de cultivo, que pide climas más benévolos, o lugares más protegidos, como lo es por ejemplo la quebrada de Toconao (...). Además de las tierras en Peine, los pobladores de este lugar ocupan también el oasis de Tilomonte, a unos $16 \mathrm{~km}$ al sur del primero, donde cultivan especialmente maíz y trigo, además de alfalfa; hay alli aproximadamente 3 hectáreas, que se pueden cultivar; además existe abundancia de chañares y algarrobos. El agua también salobre de Tilomonte, es de gusto más agradable que el de Peine y es también más abundante. En el oasis de Tilomonte, la mayoría de los pobladores de Peine poseen, aparte de los campos de cultivo, un rancho primitivo, raras veces una casa, donde pasan algunos días en la época de los trabajos agrícolas. En general no pueden quedarse por temporadas más largas, puesto que todos ellos tienen también un pequeño campo de Peine, que deben regar y cuidar" (Mostny et al. 1934: 10-11).

En el subtítulo relativo al pastoreo agregan estos autores las prácticas sobre esta materia ya descrita en las citas de Bowman, señalando el nombre de las vegas que son usadas en común por los habitantes de Peine (1934: 29-30).

En los tiempos más recientes este patrón de poblamiento, que participa de las características andinas, ha sido definido por algunos autores como "minifundismo", y han atribuido su origen no a un patrón cultural sino a una deformación fruto del sistema de herencia. Valenzuela (1970: 90-91) sostiene que en Chiu Chiu:

"La subsistancialidad se debe particularmente al minifundismo, a la dispersión de la propiedad familiar, a la ausencia de técnicas modernas de cultivo intensivo y al desconocimiento de los mecanismos comerciales.

Una familia no sólo posee tierras en el lugar donde reside habitualmente, sino que además es común que el grupo tenga propiedades en algún otro pueblo aledaño. Así se sabe de ayquinos que poseen tierras en Turi, Cupo, Toconce, etc., $y$ viceversa, habitantes 
de aquellos pagos, tienen bienes raíces en Ayquina. La explicación de esta dispersión de la propiedad familiar se debe, principalmente, a que estos bienes se han ido adentrando al patrimonio familiar, por aquella puerta ancha y enlutada que se llama: sucesión por causa de muerte. Ya sea el causante, padre, madre, pariente o algún otro deudo.

Lo expresado deja de manifiesto la existencia del minifundismo y la dispersión de la propiedad -así como de la población-, con todas sus consecuencias negativas que tales realidades, aunadas, tienen para la economía familiar, comunitaria y nacional”.

Beaulieu (1967) destaca la composición y movimiento de la población en el oasis de Chiu Chiu, señalando que un significativo porcentaje vive fuera del pueblo ("el 16.7\% de la población total de Chiu Chiu vive ahora en Calama y el $2.8 \%$ en Chuquicamata") pero, "también familias enteras" regresan cada fin de semana. En relación a la propiedad agrega: "Encontramos en Chiu Chiu una subdivisión importante de la propiedad". "Los 157 propietarios de Chiu Chiu tienen un total de 343 predios. La mayoría de los propietarios tiene de uno a dos predios, pero hay ciertos propietarios que tienen hasta 11 predios". Agrega que:

\section{"La fragmentación que existe actualmente en Chiu} Chiu, se atribuye en gran parte a las prácticas sucesorias en que la tierra se reparte por igual entre los herederos. Además de la fragmentación legal de la propiedad, existe también una fragmentación que resulta del aporte de predios de la mujer en el matrimonio.

Los derechos sobre la tierra cultivada ahora presentan una gran ambigüedad. Según nuestra encuesta, $30.7 \%$ de los predios cultivados en Chiu Chiu se adquirieron por herencia y matrimonio, $23.2 \%$ se compraron y $46.1 \%$ son arrendados o simplemente prestados. De tal situación resulta el problema de la tenencia de predios no contiguos" (Beaulieu 1967: 94).

Como puede observarse de las cifras de esta misma autora sólo menos de un tercio de los derechos sobre las propiedades proviene directamente del mecanismo de herencia y matrimonio; el resto proviene de otras formas en la que interviene el deseo o "ideal" andino de controlar más de un territorio o piso ecológico, incluso por mecanismos europeos como la compra.
Hernández (1974) reitera los juicios de Valenzuela en lo que se refiere a la propiedad agraria. Una crítica del modelo usado por este autor para manejar esos datos puede verse en Platt (1975).

\section{Discusión y conclusiones}

Cuantía de la población

En 1972, en base a los datos de Lozano Machuca, nos atrevimos a sugerir que 2000 indígenas representarían una población total de 10000 para la provincia de Atacama en 1581, y que, seguramente, por analogía con otras situaciones postconquista conocidas, la población prehispánica anterior a 1530 sería el doble o más de esa cantidad. Esto sin mencionar los 400 indígenas uros que vivían en Cobija en esos años según esa misma fuente (Hidalgo 1972: 32-33). Hoy esas cifras nos parecen exageradas al compararlas con las que resultan para el siglo XVIII, entre 2455 en 1972 y 3655 personas en 1787. Sin embargo, los índices de despoblación que sugieren los trabajos de Dobyns (1966) para el nadir de la población indígena de 20:1 que en el Area Central Andina corresponde a 1650, o el 3.4:1 estimado por Smith (1970) para la sierra peruana (estima un 58:1 para la costa) entre $1520-25$ y 1571, indican que nuestra presunción de 1972, de ser correctos los datos de Lozano Machuca, fue modesta. ${ }^{19}$

Sin embargo estos cálculos de población total están sujetos, como hemos visto, a otra variable, que es la que acá nos hemos planteado. Si aceptamos que la población atacameña compartía con otras etnias andinas un patrón de poblamiento y de acceso a recursos, maximizando el uso simultáneo de diversos y alejados pisos ecológicos, nos encontramos

\footnotetext{
19 "Datos de la población total de la región atacamena sólo tenemos, hasta ahora, en el siglo XVIII, los anteriores corresponden a Oviedo y Lozano Machuca. El primero, refiriéndose a esta zona en 1536, cuando la hueste de Almagro regresaba rápidamente de Chile en dirección al Cusco y la población de Atacama se encontraba en guerra y escondida de los españoles, calcula, sin haber estado presente en estos hechos "hasta septeciemos hombres de guerra" (Fernández de Oviedo 1901 [1552]: 248), de lo que vendría a resultar unas 3500 personas aplicando una relación de 1:5; en 1581 tenemos los datos de Lozano Machuca que hemos citado antes, luego un gran vacío hasta la segunda mitad del siglo XVIII, de modo que a esta altura de la investigación no es posible aventurar con mediana certeza el momento ni la cantidad alcanzada en el nadir y el cénit de la población atacameña.
} 
con alternativas en el modo de calcular poblaciones durante la Colonia. Pueden surgir incongruencias entre nuestra forma de calcular tradicional y la forma andina, de origen prehispánico, de hacer este cálculo. Tal incongruencia afectaría el número de habitantes por unidad étnica y/o política, ya que el elemento de la corresidencia no es decisivo.

Como los censos coloniales, y aun los ulteriores, confunden los criterios de enumeración, hoy no sabemos en realidad -a pesar de las declaraciones de los empadronamientos y de los viajeros-a qué número ascendía el total de atacameños residentes efectivamente en Atacama o cuál era el número total de atacameños que residieran o no en Atacama. Empero, podemos postular, en base a los antecedentes que se han entregado en este trabajo, la hipótesis de que desde 1752 a 1787 las revisitas nos indican el total de atacameños residentes o no en esa área y que el empadronamiento de 1792 nos remite al total de atacameños del Curato o Repartimiento de San Pedro, que efectivamente residían en ella. No sabemos qué pasa con las cifras de Chiu Chiu ese mismo año.

\section{Patrón de poblamiento}

Los datos acá citados describen un patrón de poblamiento dinámico, del cual tenían evidencia los arqueólogos, y al que habíamos aludido con el carácter de hipótesis en 1972 (Hidalgo 1972a: 31-32). Ahora en base a los testimonios expuestos podemos decir que en el Período Histórico Colonial convivió una forma desarrollada de verticalidad (por las distancias de las "islas ecológicas", conservación de derechos y obligaciones con las unidades de origen, identidad étnica, tráfico de productos bajo la categoría de tributo, diferencias ecológicas verticales en los diferentes lugares de asentamiento) junto a formas de movilidad y asentamiento pastoril (que no debe confundirse con el arrieraje, nacido en períodos históricos coloniales y que continúa en la época republicana, destinado a abastecer las empresas mineras del desierto).

Esta actividad pastoril, en algunos casos, pareciera ofrecer las características de la trashumancia estacional, en otros, como dice Le Paige (1975), se trata de un movimiento de vaivén u otros en un mismo territorio, que exigen nuevas categorías o adecuar el término trashumancia a las distintas situaciones históricas y a las variedades que se dan en un mismo tiempo.

Agradecimientos Debo expresar mis agradecimientos a: Nelda Maggi, quien colaboró animosamente en la transcripción; Julia Córdova, que contribuyó a mejorar los textos de acuerdo a las pautas internacionales de transcripción y corrigió numerosas fallas; a Mario Rivera y John Murra, que hicieron valiosas sugerencias sobre la redacción del trabajo; a Ana Escobillana y Liliana Véliz, quienes se hicieron cargo de la mecanografía; a Tristan Platt, Lautaro Núñez, Gabriel Martínez y George Serracino, por sus constantes estímulos epistolares; en especial agradezco a Gunnar Mendoza, director del Archivo Nacional Boliviano de Sucre por su valiosa orientación y las facilidades que me otorgó para microfilmar los documentos atacameños; a Rolando Mellafe que discutió conmigo algunas ideas que pensaba publicar en este trabajo. No obstante lo anterior, cualquier error que pueda deslizarse en el texto $\mathrm{y}$ en los documentos adjuntos es de mi exclusiva responsabilidad.

\section{REFERENCIAS CITADAS}

AMPUERO, G. y J., HIDALGO, 1975. Estructura y proceso en la prehistoria y protohistoria del Norte Chico de Chile. Chungara 5: 87-124.

ARANDA, X., 1971. Algunas consideraciones sobre la trashumancia en el Norte Chico. Informaciones Geográficas. no especial, pp. 141-169.

ARCE, R., 1975. Documentos sobre la Historia de Bolivia existentes en el Archivo General de la Nación Argentina. Universidad Mayor de San Andrés, La Paz.

ARGUEDAS, J. M., 1964. Prólogo a la serie de documentos regionales para la etnología y etnohistoria andinas. En
Visita hecha a la Provincia de Chuicuito por Garci Diez. de San Miguel en el año 1567. Casa de la Cultura de Perú, Lima.

BARNADAS, J., 1973. Un documento sobre la Revolución de Chayanta, 1780. En Historia y cultura, pp. 143-163. Revista de Instituto de Estudios Bolivianos, Sección Cultura, División de Extensión Universitaria, Universidad Boliviana. Universidad Mayor de San Andrés. Número preparado por la Sociedad Boliviana de Historia, La Paz.

BEAULIEU, A., 1967. El hábitat humano y la economía agrícola en el oasis de Chiu Chiu. Revista de la Universidad del Norte 4: 81-101. 
BERTRAND, A., 1885. Memoria sobre las cordilleras del Desierto de Atacama y regiones limítrofes. Con varios mapas $y$ vistas. Santiago.

BOWMAN, I., 1924. Desert trails of Atacama. Special Publication American Geographical Society 5, Nueva York.

- 1942. Los senderos del Desierto de Atacama. Sociedad Chilena de Historia y Geografía. Santiago

CAÑETE, P. V., 1952 [1787]. Historia física y política de la provincia de Potosí, vol. 1. Fundación Universitaria Simón I. Patiño, La Paz.

CARMAGNANI, M., 1963. El salariado minero en Chile colonial. Su desarrollo en una sociedad provincial. El Norte Chico 1690-1800. Universidad de Chile, Centro de Historia Colonial de la Facultad de Filosofía y Educación, Santiago.

CASASSAS, J. M., 1974a. La región atacameña en el siglo XVII. Datos históricos socioeconómicos sobre una comarca de América meridional. Incluye, en apéndice, la transcripción completa del Libro de varias ojas 1611-1698, de la Parroquia de Chiu Chiu, el conjunto documental más antiguo de la Región Atacameña. Edición revisada, de la tesis para obtener el Grado de Doctor en Filosofía y Letras, Sección Historia, Universidad de Madrid.

— 1974b. Noticias demográficas de la región atacameña durante el siglo XVIII. Estudios Atacameños 2: 75-92.

— 1974c. Fuentes documentales para el estudio etnohistórico de las poblaciones indígenas del Norte Grande chileno y tierras adyacentes. Centro de Documentación, Repertorio Bibliográfico 3. Universidad del Norte, Antofagasta.

DOBYNS, H. F., 1966. Estimating aboriginal American population: An appraisal of technique with a new hemispheric estimate. Current Anthropology 7 (4): 395-449.

ESPINOZA MORAGA, O., 1958. La postguerra del Pacífico y la Puna de Atacama (1884-1899). Editorial Andrés Bello, Santiago.

FERNANDEZ DE OVIEDO y G. VALDES, 1901 [1552]. Historia general y natural de las Indias islas y tierra firme del mar océano. En Colección de Historiadores de Chile y de Documentos Relativos a la Historia Nacional vol. XXIII: 1-254. Imprenta Elzeviriana, Santiago.

HADDEN, G. J., 1967. Un ensayo de demografía histórica y etnológica en Huánuco. En Visita de la Provincia de León de Huánuco, por Iñigo Ortiz de Zúñiga, vol. 1. J. Murra (Ed.), pp. 371-380. Universidad Emilio Valdizán, Huánuco,

HERNANDEZARACENA, R., 1974. Chiu Chiu: La desintegración de la comunidad tradicional. Antropología 1: 17-33.

HIDALGO, J., 1972. Culturas protohistóricas del norte de Chile. El testimonio de los cronistas. Cuadernos de Historia 1.

— 1972b. Algunas notas sobre los mapuches protohistóricos. En Tercera semana indigenista. Universidad Católica de Chile, Temuco.
— 1977. La rebelión indígena de 1781 en el norte de Chile. Una versión provincial de la sublevación de Tupac Amaru, Arica, Tarapacá y Atacama. Chungara 6.

LE PAIGE, G., 1975. ¿Se puede hablar de trashumancia en la zona atacameña? Estudios Atacameños 3: 11-16.

LOZANO MACHUCA, P., 1581. Carta del factor de Potosí (al Virrey de Perú Don Martín Enríquez) en que da cuenta de cosas de aquella Villa y de las minas de los Lipes (y de Atacama). Separata del Boletín 2-3 del Centro de Documentación, año 1972. Universidad del Norte, Antofagasta.

LUMBRERAS, L. G., 1974. Los reinos post-Tiwanaku en el área altiplánica. Revista del Museo Nacional de Lima XI: 55-85.

LYNCH, T., 1975a. Algunos problemas básicos del estadio de caza-recolección andina: Trashumancia. Estudios Atacameños 3: 7-10.

- 1975b. La cosecha inoportuna, trashumancia y el proceso de domesticación. Estudios Atacameños 3: 75-80.

MALAGA, A., 1975. Paleografía hispanoamericana. Universidad Nacional de San Agustín, Programa Académico de Historia, Geografía y Antropología, Arequipa.

MAYER, E., 1972. Censos incensatos. Evaluación de los censos campesinos en la historia de Tangor. En Visita de la Provincia de León de Huánuco en 1562 por Iñigo Ortiz de Zúñiga, vol. 2. J. Murra (Ed.), pp. 339-365, Universidad Emilio Valdizán, Huánuco.

MELLAFE, R., 1972. Descripción tipológica de los documentos útiles para la demografía histórica existente en los archivos latinoamericanos. Centro Latinoamericano de Demografía, CELADE, serie D, $\mathrm{n}^{\circ} 71$, Santiago.

MOSTNY, G., F. JELDES, R. GONZALEZ y F. OBERHAUSER, 1954. Peine, un pueblo atacameño. Publicación 4 del Instituto de Geografía, Facultad de Filosofía, Universidad de Chile, Santiago.

MURRA, J., 1972. El "control vertical” de un máximo de pisos ecológicos en la economía de las sociedades andinas. En Visita de la Provincia de León de Huánuco en 1562 por Iñigo Ortiz de Zúniga, vol. 1. J. Murra (Ed.), pp. 427-476, Universidad Emilio Valdizán, Huánuco.

—1975. Formaciones económicas y políticas del mundo andino. Instituto de Estudios Peruanos, Lima.

NUÑEZ, L., 1975. Dinámica de grupos precerámicos en el perfil costa-altiplano (norte de Chile). Estudios Atacameños 3: 59-74.

NUÑEZ, L., V. ZLATAR y P. NUÑEZ, 1975. Un circuito trashumántico entre la costa de Pisagua y el borde occidental de la Pampa del Tamarugal. Estudios Atacameños 3: 49-52.

OTERO, G. A., 1975. La vida social en el coloniaje. Esquema de la Historia del Alto Perú, hoy Bolivia de los siglos XVI, XV11 y XVIII. Biblioteca del Sesquicentenario de la República, La Paz. 
PLATT, T., 1975. Reseña bibliográfica del artículo de Roberto Hernández: Chiu Chiu: La desintegración de la comunidad tradicional. Chungara 5: 153-158.

PODESTA, J., 1975. Notas demográficas sobre Camiña y Silbaya, comprendiendo el período 1600-1900. Cuadernos de Investigación Social 1.

PONCE, C., 1975. Apuntes para el estudio de la demografía histórica de Tiwanaku durante el Período Colonial. Publicación 9 del Instituto Nacional de Arqueología, La Paz.

ROSENBLATT, A., 1954. La población indígena y el mestizaje en América. Editorial Nova, Buenos Aires.

SAAVEDRA, B., 1938. El ayllu. Estudios sociológicos. Editorial Nascimento, Santiago.

SCHIAPPACASSE, V. y H. NIEMEYER, 1975. Apuntes para el estudio de la trashumancia en el valle de Camarones (prov. de Tarapacá, Chile). Estudios Atacameños 3: 53-57.
SERRACINO, G., 1975. Los movimientos de cazadores recolectores en la Cordillera de los Andes entre la latitud $21^{\circ}$ y $26^{\circ}$ y longitud $67^{\circ}$ y $70^{\circ}$ 22. Estudios Atacameños 3: 17-43.

SERRACINO, G. y R. STEHBERG L., 1975. Vida pastoril en la precordillera andina. Estudios Atacameños 3: 81-99.

SMITH, C. T., 1970. Depopulation of the Central Andes in the $16^{\text {th }}$ century". Current Anthropology 11 (4-5): 453-464.

SPALDING, K., 1974. De indio a campesino. Cambios en la estructura social de Perú colonial. Instituto de Estudios Peruanos, Lima.

STOCKWELL, E. G., 1970. El hombre y los problemas demográficos. Bibliográfica Omeba, Buenos Aires.

VALENZUELA, B., 1970. Epítome etnográfico de la cuenca del río Salado, provincia de Antofagasta. Chile. Boletín de Prehistoria de Chile 2 (2-3): 75-99.

VARGAS, R., 1956. Historia de Perú. Virreinato (siglo XVIII) 1700-1790. Lima. 


\section{Anexo 1: Transcripción Paleográfica de Documentos realizada por Jorge Hidalgo y Nelda Maggi}

1. Informe y Decreto de la Revisita de Atacama, perteneciente a la Intendencia de Potosí, (1787). En Biblioteca de la Real Academia de Historia de Madrid, Colección Mata Linares, tomo XIII 9-9-2- (1688), folio 20-22 vta. También en Biblioteca Nacional de Chile, Sala Medina, tomo 200. Doc. 4895. (Descripción del $n^{\circ} 302$, repertorio bibliográfico $n^{\circ} 3$, Casassas). Transcripción documento 4895 del tomo 200 Sala Medina.

M f24r.

2. Pino Manrique, Juan del. Oficio de D. ...... A D. Francisco de Paula Sanz sobre la Revisita en el Partido de Atacama. 1797. En Biblioteca de la Real Academia de Historia de Madrid, Colección Mata Linares, tomo XIII 9-9-2-1688, fol. 23. También en Biblioteca Nacional de Chile, Sala Medina, tomo 200, doc. 4896. $\left(\mathrm{n}^{\circ} 354\right.$. del repertorio Bibliográfico $\mathrm{n}^{\circ} 3$ de Casassas). Transcripción documento 4896 del tomo 200 Sala Medina.

M ft9r.

3. Informe de la Contaduría de Retasas sobre la Revisita del Partido de Atacama (1790). En Biblioteca de la Real Academia de Historia de Madrid, Colección Mata Linares, tomo XIII, 9-9-2-1688. folio 24-25 vta. También en Biblioteca Nacional de Chile, Sala Medina, tomo 200 , doc. 4897 . ( $n^{\circ} 300$ del Repertorio Bibliográfico $n^{\circ} 3$ de Casassas). Transcripción documento 4897 del tomo 200, Sala Medina.

M f31r.

4. Demostración de la Contaduría de Retasas sobre el número de contribuyentes empadronados en la Revisita del Partido de Atacama en el año 1787. En Biblioteca de la Real Academia de Historia de Madrid, Colección Mata Linares, tomo XIII, 9-9-2-1688, folio 26. También en Biblioteca Nacional de Chile, Sala Medina. Tomo 200. Doc. 4898. (nº 295 del Repertorio Bibliográfico no 3 de Casassas) Transcripción documento 4898 del tomo 200 Sala Medina.

M f36r.

5. Informe de la Contaduría de Retasas sobre la revisita del Partido de Atacama de 1787. (1792). En Biblioteca de la Real Academia de Historia de Madrid, Colección Mata Linares, tomo XIII, 9-9-2-1688, folios 27-28 vta. También en Biblioteca Nacional de Chile, Sala Medina, tomo 200, doc. 4899. (nº 301 del Repertorio Bibliográfico no 3 de Casassas). Transcripción documento 4899 del tomo 200 Sala Medina.

M f39r.

6. Aprobación de la Revisita del Partido de Atacama. Buenos Aires, ... 1792. En Biblioteca de la Real Academia de Historia de Madrid, Colección Mata Linares, tomo XIII, 9-9-21668, folio 29. También en Biblioteca Nacional de Chile, Sala Medina, tomo 200, doc. 4900. ( $\mathrm{n}^{\circ} 291$ del Repertorio Bibliográfico ${ }^{\circ}$ de Casassas). Transcripción documento 4900, tomo 200, Sala Medina.

M f41r.

7. Rubin de Celis, Pedro Manuel y Arce (José Agustín de). Extracto de los dos Repartimientos del Partido de Atacama, distancias, tributarios y líquido importe, redactado por quienes habían efectuado la Revisita. 1787. = En Biblioteca de la Real Academia de Historia de Madrid, Colección Mata Linares, tomo XIII, 9-9-2-1668, folio 30. También en Biblioteca Nacional de Chile, Sala Medina, tomo 200, doc. 4901 y 4902 . ( ${ }^{\circ} 359$ del Repertorio Bibliográfico $\mathrm{n}^{\circ} 3$ de Casassas). Transcripción documentos 4901 y 4902, tomo 200, Sala Medina.

M f45r.

8. Revisita de Atacama, concluida en 10 de junio de 1804. Archivo Nacional Boliviano, Sucre, Catálogo de Revisitas, nº 198, Dep. de Potosí; Prov. Atacama; Padrón; Año 1804 fs. 43. 


\section{1) Revisita del Partido de Atacama Intendencia de Potosí de año 1787 febrero 23 de 1787}

Muy señor mío. En medio que han sido eficases nuestro reseo [¿deseo?] y empeño de concluir anticipadamente la Revisita de los Indios y demás castas que hay en este Partido, sugetas a tributos, ha sido imposible en menos de los quatro meses, que hemos empleado en su actuación, a causa de que muchos del repartimiento de San Pedro de Atacama viven radicados de inmemorable tiempo en diferentes lugares de la Jurisdicción del Tucumán y tan distantes de los de su origen que les ha sido indispensable la demora para venir hasta ellos a ser empadronados como hera regular. Al fin la hemos concluido con aumento de 81 Indios, que quedan efectivos en la clase de Tributarios sobre el número de 648, que ya lo contribuían desde el año de setecientos setenta y siete, que fue cuando se practicó la última Matrícula de este Partido por el mismo Subdelegado, que hoy los sirve en virtud de especial comisión de la Real Audiencia del distrito $=$ Si se atienden las escasas proporciones, ya del Terreno, como de los demás exercicios de industra en que se emplean, estos naturales, es fácil comprexhender lo poco apetecible que es a otros Yndios que no sean/ de su respectivo Origen y este es el motivo por que a excepción, de los Forasteros que se hallan agregados al Asiento de Conchi, y de uno tal que otro entre los pueblos, y ayllos de su Jurisdicción no hay número de los de esta clase como regularmente se hecha de ver en aquellos Partidos que abundan de Minas, u otros lucrosos exercicios, quando no ofrescan el mejor acogimiento en la fertilidad del Terreno; sobre este supuesto deve estimarse proporcionado el aumento que resulta de la Revisita, que acava de executarse atendida la corta entidad de su entero, los muchos que resultan ausentes sin saverse de ellos, y sobre todo, que por ser sumamente extériles las tierras, que disfrutan en sus Repartimientos, viven separados los más en las distancias, por que no es fácil reducirlos a la sugeción que sólo puede evitar el mayor extravío = Por las mismas razones se hace impracticable la disposición del Artículo 44 de la Instrucción metódica de Revisita dirigida a que se entable la satisfacción de los tributos por tercios que quatro meses, pues aún hallándose los Caciques de este citado Partido en la proceción de verificarlo por medios años no pueden aún cumplido este término juntarse con el todo de la recaudación, especialmente de aquellos que viven en la Jurisdicción de la Intendencia de Salta, hasta donde con los mayores trabajos y no pocas espensas tienen que conducirse, y en muchos casos con riesgo de perde la vida en el tránsito de la Cordillera que tienen que andar por término de ocho días, y a este tenor es tan penosa la cobranza que toda ipérbole es corta para significar los atrazos, y demás inconvenientes que le ofrece su responsavilidad al subdelegado, como ya lo representó a Vuestra Señoría en otra ocasión y últimamente lo ha repetido el Comisionado de Visita a concequencia de las Providencias con que ha estudiado [?] por los tercios de Navidad y San Juan del año próximo anterior, con cuio objeto, y de que se le otorgue más término para los sucecivos enteros vuelve a repetir sus Clamores a la Justificación de Vuestra Señoría con el seguro, de que por las mesmas diligencias que se han practicado al propósito, se graduara otro tanto justa su Solicitud = Con el mismo objeto de asegurar la Cobranza de Tributos por lo respectivo á los Indios que viven en la Jurisdicción del Tucumán se ha tenido por combeniente nombrar en los Pueblos de Toconao, Soncor, Peyne y Socaire en cada uno dos cobradores, y en el primero tres y un segundo mediante á que no de otro modo, puede lograrse el todo de la Recaudación por la suma distancia que los separa de los diferentes lugares de su residencia que hay muchas que distan entre sí no/ menos que ochenta o cien leguas y por esta causa siempre se han tenido por excemptos de Tributos los Citados cobradores, como ahora ygualmente van entre los de esta clase en el ínterin exercer sus empleos $=$

Aunque todos o la mayor parte de los Tributarios pagan su respectiva asignación en frutos de labranza, o en otras especies de Industria, tienen acentado con los Cobradores el equivalente precio o su estimación, y así nunca quedan perjudicados, y más bien los Caciques sufren algún atrazo en la demora, que suelen padecer en darle expendio para cubrirse del dinero 
que anticipan regularmente en muchos casos, y especialmente por aquellos que no tienen mayor posible, y sobre este supuesto no hay entre ellos la discordia que podía motivar otra mala versación $=$ Con concepto a lo que llevamos expuesto en este informe puede Vuestra Señoría desde luego deliverar quanto le paresca, de su superior agrado, en inteligencia que de de nuestra parte se ha puesto todo el empeño para perfeccionar los Encargos de su respectiva instrucción por el mejor servicio del Reyno menos que por acreditar el que por todos títulos les es devido $=$ Nuestro Señor guarde la importante vida de Vuestra Señoría muchos años Chiu Chiu y febrero 23 de 1787 = B.L.M. [Besa las manos] de Vuestra Señoría su más atento Servidor $=$ Doctor José Agustín de Arce $=$ Pedro Manuel Rubin de Celix $=$ Señor Governador IN/ tendente Doctor Donjuán del Pino Manrrique.

/f28r.

Decreto Potosí 26 de marzo 1787 = Por recivida en la Matrícula Original y sus testimonios que la acompañan y dirigiéndose aquella en primera ocasión a la Junta Superior de Real Hazienda y éstos a los Ministros principales con arreglo al Artículo 122, de la Real Ordenanza de Intendencias y al 49, de Revisita, se pasará por los citados Ministros certificación por triplicado del aumento que se note de Tributarios por esta Revisita que deve seguir desde su fecha como está prevenido y en quanto al más término para los Enteros, que solicita el Subdelegado de Atacama, se reserva su resolución á la citada Junta Superior, avisándose de esta dispocición a los representantes, y ministros referidos por medio de oficios que se entenderán por mi Secretaria $=$ Una rubrica $=$ Veles .

Es copia del Informe y decreto originales de su Contexto, que queda en esta Secretaría de mi cargo que Certifico. Potosí 16 de abril de 1787 = Manuel José de Velles.

2) Dirijo a Vuestra Señoría en $f$. 137 útiles los autos de Revisita practicada en el partido de Atacama de esta Jurisdicción con arreglo a las prevenciones de la Instrucción metódica dispuesta para esta Operación por el Señor Don Jorge Escobedo Visitador General que fue de este Reyno $=$ El aumento resultado por ella es de ochenta y un indios, cuio Tributo asciende á setecientos ochenta y tres pesos, suma no comparable con la que ha producido esta Operación en otros Partidos: pero si correspondiente al número de havitantes de aquel, que por su extraviada situación e inmediación a la Provincia de Salta pierde muchos en los términos, que manifiesta la representación del Subdelegado, y Apoderado Fiscal encargados de esta Operación que me dirijieron con fecha 23 de febrero próximo pasado y acompañó en copia certificada $=$

Por la Provincia de 26 de marzo siguiente que extendí en ella, y también inserta la expresada copia se enterara Vuestra Señoría haver dexado a la resolución de la Junta Superior de Hazienda el punto de Esperas para los enteros de Tributos que solicita el Subdelegado, y sobre que se ha substanciado Expediente que dirijo a V.S. por separado al $\mathrm{N}^{\circ}$ esperando se sirva nombrar, mandar darme aviso del/ resivo de la expresada Revisita para la devida constancia = Nuestro Señor guarde a Vuestra Señoría muchos años.

/f29r.

Potosí 16 de abril de $1787=$ Juan del Pino Manrique $=$ Señor Superintendente Subdelegado Don Francisco de Paula Sanz = 

octubre 6 de 1790

Excelentísimo Señor = En Cumplimiento del Decreto de Vuestra Señoría de 31 de Mayo de 1787, que antecede ha reconocido el encargado provisionalmente de la Contaduría de Retaza la nueva Revisita y empadronamiento del Partido de Atacama en la Provincia de Potosí, que actuo con las formalidades prevenidas, su Subdelegado Don Pedro Manuel Rubin de Celis con intervención del Apoderado Fiscal Don José Agustín de Arce desde 16 de noviembre de $1787^{(6)}$ que la principió en la Cavezera hasta 5 de febrero de 1787 que la concluyó numerando en todo el 729, Tributarios utiles los 703. Originarios de Tasa de 10 pesos y los 26 restantes Forasteros sin Tierras de la de 7 pesos, entre los cuales hay 27 cholos de la primera Clase y uno de la $2^{\mathrm{a}}$, que están en costumbre de Tributar que todos han de contribuir anualmente 7212,, pesos y haviendose empadronado en la ultima anterior Revisita practicada el año de 1752,, 491,, Tributarios los 475, Originarios, y 16, forasteros, cuia gruesa ascendia a 4.862 pesos resulta el aumento de 238 Contribuyentes, y la ventaxa a favor del Ramo de Tributos de 2350. pesos en cada año como manifiesta la demostración que acompaña f7 bien que según expresa el Señor Intendente/ de Potosí en el Oficio de Remisión f9 solo ha producido el aumento de 81 Tributarios que han de satisfacer 783 pesos cuia diferencia procederá de aumentos dados en el intermedio de una á otra Revisita sin noticia de esta Contaduría en la qual con arreglo al articulo 123 de la Ordenanza de Intendentes deve manifestarse el aumento ó disminución comparando la Revisita actual con la ultima anterior $=$ En la misma demostración se manifiesta por clases el número de personas de ambos sexos que se han empadronado y entre ellos 251 reservados, cuio total se compone de 201 mayores de 50 años, o impedidos, 9 sirvientes de Iglesia, 5 por enfermedad temporal, 11, Alcaldes 5 Govemadores, 14 Curacas, y 3 segundas, entre los quales no ofrecen duda en sus reservas los mayores de 50 años, ni tampoco los sirvientes de Iglesias, que vienen reducidos a menor número que en la Revisita anterior, en la qual se reserbaron seis en cada Repartimiento como se hacia por punto general, por consiguiente solo resta tratar de las demás clases $=$ Los reservados interinamente por enfermedad temporal deven quedarlo por ahora con arreglo a lo declarado por Vuestra Excelencia en el Auto de Aprovación de la Revisita del Partido de Pacages, y a lo que dispone la Instrucion de Matriculas; fuera de que los 5 que comprehende el de Atacama son muy / pocos con respecto a los que se dan en otras Matriculas $=$ Los 11, Alcaldes de los quales 9 tienen más de 50 años, y los 5 Governadores en quienes también hay uno mayor de edad, goza de reserva por el Artículo 27 de la Instrucción de matrículas en conformidad del 126, de la Ordenanza de Intendentes los Curacas que son 14, y de ellos uno mayor de edad deven considerarse también exceptuados estandolo los Caciques por las Leyes y Ordenanzas, mediante que Curaca y Cacique al parecer son Sinonimos, nombrados de uno y otro modo según el idioma de las Provincias o el uso antiguo de ellas, pero la Esencion de los Segundas, que son 3,2 , de ellos en edad de tributar, no está apoyada en las Leyes, ni en otra alguna disposición además de esto se presenta desde luego la reflecion de que es excesivo el número de Tributarios y la practica de las demas Intendencias del Reyno en donde por lo regular sólo contiene cada repartimiento un Cacique, y algún Alcalde, bien que los encargados de la Revista en su Oficio de $\mathrm{f}^{\mathrm{a}}{ }^{\mathrm{a}}$ de este Expediente se hacen cargo de este punto y exponen la necesidad que hay destas manos auxiliares para asegurar la recaudación de Tributo por las distancias largas de unos a otros parages; y por la dificultad de las Cobranzas, por cuia razón dicen que siempre se ha hecho lo mismo, y efectivamente de las anteriores ultimas Retazas costa haverse reservado 21,/ Cacique de los dos Repartimientos del Partido de que se va tratando, que el numero ygual al de todos los Comprehendidos en este Capitulo rebaxados los mayores de edad que gozan la esención solo por esta calidad, aunque no sirvan Los Oficios con que van distinguidos -En esta atención parece que por ahora deven quedar reservados todos, y por consiguiente siendo Vuestra Excelencia servido podrá aprovar y confirmar dicha Revisita, mandando se formen las liquidaciones que han regir para el cobro, distribución, y Cuenta de Ramo del Tributos, pues para que en lo sucesivo se arregle el punto de reservas, con fecha de hoy hace a Vuestra Excelencia por separado esta Contaduria la consulta que ha jusgado necesaria en la qual se trata también los demás puntos que abraza el Oficio de los Comisionados para que de este modo no se retarde mas la aprovación de la Matrícula. Buenos Ayres 6 de octubre de $1790=$ Excelentisimo Señor $=$ Matias Bernal. 


\section{4) PROVINCIA DE POTOSI PARTIDO DE ATACAMA}

Demostración que forma la contaduría de Retazas del Virreynato de Buenos Ayres para manifestar el número de contrivuyentes; y demás personas de todas clases y edades de Casta Tributaria que se han empadronado en las Revisitas practicada en el Partido de Atacama de la Provincia de Potosí por el Juez Subdelegado de el Don José Agustín de Arce desde 16, de Noviembre de 1786,, que la principio en la Cavezera hasta 5 de febrero de 1787 que la concluyo; como tambien para manifestar el imponerte de los Reales tributos con que deve contribuir anualmente el expresado Partido, y la diferencia que resulta de la actual Matrícula a la última anterior.

\begin{tabular}{|c|c|c|c|c|c|c|c|c|c|c|}
\hline 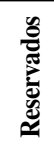 & 兽 & 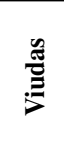 & 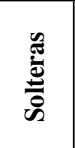 & 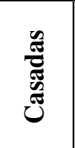 & & 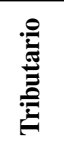 & 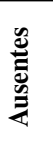 & 兰 & $\stackrel{气}{\varrho}$ & 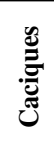 \\
\hline \multicolumn{11}{|c|}{ Originarios con tierra de Tasa $10 \mathrm{p}^{\mathrm{s}}$. } \\
\hline 203 & 384 & 138 & 501 & 467 & San Pedro de Atacama & 568 & 54 & 161 & 374 & \\
\hline 40 & 82 & 15 & 77 & 95 & San Francisco de Chiuchiu & 108 & 5 & 37 & 126 & \\
\hline \multirow[t]{2}{*}{243} & 466 & 156 & 578 & 562 & 243 & 676 & 59 & 198 & 500 & \\
\hline & & & & & Cholos con tierras de la misma tasa $Y$ & & & & & \\
\hline 3 & 13 & 2 & 9 & 9 & $\mathrm{~S}^{\mathrm{n}}$ Pedro de Atacama & 14 & 1 & 7 & 16 & \\
\hline 0 & 4 & 1 & 0 & 5 & $\mathrm{~S}^{\mathrm{n}}$ Francisco de Chiuchiu & 13 & 0 & 2 & 13 & \\
\hline 246 & 483 & 159 & 587 & 576 & 246 & 703 & 60 & 207 & 529 & \\
\hline \multicolumn{11}{|c|}{ Forasteros sin tierras de Tasa de 7 pesos } \\
\hline 0 & 1 & 0 & 1 & 4 & $\mathrm{~S}^{\mathrm{n}}$ Pedro de Atacama & 4 & 1 & 1 & 1 & \\
\hline 4 & 14 & 3 & 6 & 14 & $\mathrm{~S}^{\mathrm{n}}$ Francisco de Chiuchiu & 21 & 0 & 4 & 18 & \\
\hline 4 & 15 & 3 & 7 & 18 & 4 & 25 & 1 & 5 & 19 & \\
\hline \multicolumn{11}{|c|}{ Cholos sin tierras de la misma tasa } \\
\hline 1 & 2 & 0 & 0 & 3 & San Francis ${ }^{\text {co }}$. de Chiuchiu & 1 & 3 & 1 & 0 & \\
\hline \multirow[t]{2}{*}{5} & 17 & 3 & 7 & 21 & 5 & 26 & 4 & 6 & 19 & \\
\hline & & & & & Resumen General & & & & & \\
\hline 246 & 483 & 159 & 587 & 576 & 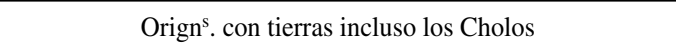 & 703 & 60 & 207 & 529 & \\
\hline 5 & 17 & 3 & 7 & 25 & Forasteros sin tierras incluso los Cholos & 26 & 4 & 6 & 19 & \\
\hline 251 & 500 & 162 & 594 & 597 & $\begin{array}{l}\text { Son } 3658 \text { personas; } 1805 \text { hombres: } 1859 \mathrm{mg}^{\mathrm{s}} \text {. Cotexo de la } \\
\text { actual Matrícula con la última anterior } \mathrm{p}^{\mathrm{a}} \text {. manifestar el número } \\
\text { de Tribus. su contribución y la ventaja resultante. }\end{array}$ & 729 & 64 & 213 & 548 & \\
\hline \multicolumn{5}{|c|}{$\begin{array}{l}\text { Originarios con tierras } \\
\text { de tasa de } 10 \text { pesos }\end{array}$} & Forasteros sin tierras de tasa de 7 pesos & \multicolumn{5}{|c|}{ Importe total de pesos corrientes } \\
\hline \multicolumn{4}{|c|}{ Lo que resulta de la actual } & 703 & 26 & \multicolumn{5}{|c|}{7212} \\
\hline \multicolumn{4}{|c|}{$\begin{array}{l}\text { Resultando de la última } \\
\text { anterior practicada en el } \\
\text { año de } 1752\end{array}$} & 475 & 16 & \multicolumn{5}{|c|}{4862} \\
\hline \multicolumn{4}{|c|}{ Resulta el aumento de } & 228 & 10 & \multicolumn{5}{|c|}{2350} \\
\hline
\end{tabular}

Por manera que haviendose empadronado en todo el Partido del Atacama 3618 personas 1808 hombres y 1853 mugeres, se han hallado729 Tributarios, útiles los 703 Originarios con tierras y 26 restantes Forasteros sin Tierras que han de satisfacer annualmente 7212 pesos y consintiendo el numero de la ante rior Revisita 
practicada en el año de 1752 en 491, Tributarios los 475 Originarios y los 16 Forasteros, cuia gruesa ascendia a 4862 pesos resulta el aumento de 228 Contribuyentes que han de satisfacer anualmente 2350 pesos cuia Cantidad es mas producto del ramo de tributos en cada año.

Nota

Que en Oficio con que remito la Matricula el Intendente de Potosí manifiesta haver producido el aumento de 81 Indios que han de pagar 783 pesos y la diferencia hasta los 2350 pesos que se ha demostrado procedera de aumentos que se havran dado en el intermedio que ha havido desde una a otra Revisita sin noticia de esta Contaduría $=$ Matias Bernal. $=$

\section{5) Informe de la Contaduría de Retasa en la Revisita del Partido de Atacama del año 1787. noviembre 8 de 1792}

f38r.

Señores de la Junta Superior = El Oficial primero de la Contaduría general de Exto [sic] y Real Hazienda encargado provicionalmente del la contaduría de Retazas a Vuestra Excelencia hace presente que como por las ocurrencias extraordinarias, que han mediado se ha retardado el despacho de las Revisitas de todo el Reyno, y además de haver cumplido su término se ha representado de varias partes la necesidad de actuar, será muy conveniente el que se trate quanto antes de la Aprovación de las que todavía están pendientes, así por la razón expresada, como porque estándose ya actuando muchas Revisitas sucederá regularmente que dentro de poco empezarán a venir las nuevas, y como la Contaduría se halle embarazada con las que hay rezagadas tal vez lo podrá evacuar sus operaciones con la brevedad que exige estos asumptos, no sólo executivos por su naturaleza, sino de tal calidad que no haciéndose en tiempo vienen a ser infructuosas = Por esto cree muy propio de su obligación el Contador Comisionado presentar Vuestra Excelencia el expediente de la Revisita de Atacama; porque según su estado no encuentra ningún genero de incombeniente para que Vuestra Excelencia se sirva aprovarla en el modo provisional y conforme a las circunstancias, que Vuestra Excelencia ha/ tenido á bien adoptar para otras de la misma Provincia supuesto que por él se provee de las noticias necesarias al Estado de Cuentas, y a las Caxas Reales, y se da una especie de Instrucción para lo sucesivo = El Estado del Expediente se reduce á que haviéndose reconocido la Matrícula en esta Contaduría y expuesto lo conveniente, sobre su contenido, llevando Vuestra Excelencia la prudente máxima de arreglar estos asumptos de manera, que no hay tropiezos, ni detenciones en lo sucesivo, se sirvió, Vuestra Excelencia mandar que informase el Señor Intendente de la Provincia sobre varios puntos, cuya contextación devía ya haver venido hace mucho tiempo, habiéndose dirigido el Oficio correspondiente en 26 de diciembre del año anterior y esta retardación unida a las circunstancias de haverse representado sobre la necesidad de nueva Matrícula exige al parecer tomar el medio, que queda propuesto. $=$ Dos son los reparos advertidos en la Matrícula pendiente, el primero consiste en las reservas, de los Alcaldes, Caciques, Curacas Governadores, y segundas porque parece excesivo su número, aunque las Circunstancias del Partido hacen necesario mayor número que en otras partes; sobre cuio particular nada puede remediarse por lo pasado, y bastará prevenir al Señor Intendente que arregle al tiempo de la nueva Revisita el número preciso de estas clases, y supuesto que en las Leyes, y en las Instrucciones está determinada la reserva, sólo para los Caciques Governadores, y Alcaldes, que se ponga los necesarios para estos destinos sin aumentar otros títulos, y guardando en su nombramiento el orden prevenido $=$ El segundo procede de los Reservados interinamente por enfermo de dudosa curación, los quales deven quedarlo por ahora con arreglo a lo resuelto

/f39r.

f40r. 
por Vuestra Excelencia en Otros Expediente, pero es necesario prevenir que se tenga mucho cuidado en que sólo se atienda para con aquellos en que se conozca absoluta imposibilidad de contribuir y con la calidad, de que en cada tercio se haga constar en la Caxa Real si han recobrado algunos su saluz [sic] para que desde entonces constribuya con sus respectivas Tasas $=$ Por manera que según lo expuesto habiéndose cumplido el término de la Revisita y siendo necesario actuar otra según se ha representado, nada puede remediarse por lo pasado, si es que hay algo digno de reforma en los puntos expresados, y lo que conviene es prevenir lo necesario para que se tenga presente en la nueva Revisita en cuyo concepto será muy oportuno que Vuestra Excelencia se sirva seguir el método adoptado para otras partes, sin experar la respuesta, que ha detenido el Espediente y que puede presumirse se haya extraviado mediante que nada podrá contener que influia para lo pasado, o lo que Vuestra Excelencia considere más conveniente. Buenos Ayres 8 de noviembre de 1792 = Matías Bernal.

\section{6) Buenos Ayres 12 de diciembre de 1792}

Vistas con lo ynformado por la Contaduría de Retazas Tribunal de Cuentas y lo expuesto por los Señores Fiscales, teniendo concideración a la necesidad de una nueba Revisita representada por el Señor Intendente de la Provincia de Potosí se aprueva la practicada en el Partido de Atacama por sus Subdelegados Don Pedro Manuel Rubin de Celis con intervención del Apoderado Fiscal Don José Agustín de Arce desde 16 de noviembre de 1786 hasta 5 de febrero de 1787 en su consecuencia devuélvase los autos a la Contaduría para que forme por ahora (sin que sirva de exemplo en adelante) un Estado en que con distinción de repartimientos, y la devida claridad se demuestre el número y clase de Tributarios sus Tasas y la gruesa de Tributos que deben pagar de modo que sirva para govierno de los Enteros en la Tesorería de Potosí y para conocimiento del Tribunal de Cuentas mediante que haviéndose cumplido el período de los cinco años que deve mediar de una a otra Revisita, y ser necesaria la actuación de otra sobre ser infructuosa en tales circunstancias la extensión que exige la formalidad de las Proviciones de Retazas produciría el perjudicial efecto de impedir el pronto despacho de las demás Matrículas que se ha retardado por las particulares ocurrencias que han mediado. Y para que la nueva Revisita se rectifiquen o enmienden los puntos notados por la Contaduría de Retazas/

$1^{\text {a }}$. Se observarán las prevenciones siguiente Que aunque por ahora han de quedar reservados los Tributarios enfermos de dudosa curación deve poderse en menor [sic] cuidado en que se haga solo en los casos en que se conosca absoluta imposivilidad de contribuir, y con la Calidad de que en cada tercio se haga constar en la Caxa Real si algunos han recobrado su salud para que desde entonces constribuyan con sus respectivas Tazas. $=$

$2^{\mathrm{a}}$. Resultando haverse reservado en este Partido un número considerable de Alcaldes, Curacas, Governadores, y segunda tendrá cuidado el Señor Intendente de la Provincia de que no haya exceso vicioso en lo sucecivo, y supuesto que las Leyes y las instrucciones reservan a los Caciques, a los Governadores, y a los Alcaldes de que se pongan los necesarios para estos desinos excusando otros títulos y guardando en sus nombramientos el orden prevenido. A cuyo fin y para los demás efectos que deve producir este auto, se remitirá Testimonio de él al Señor Intendente de la Provincia de Potosí con copia del Estado que ha de reformar la Contaduría para que se comunicará a las Caxas Reales y tomándose razón en el Tribunal de Cuentas, archívese todo en la Contaduría de Retazas en la qual se formará liquidación de las dietas que han devengado los empleados en la Revisita. $=$ Arredondo $=$ Matta - Velasco $=$ Cabrera $=$ Pinedo $=$ Pedro - de Velasco. 
JORGE HIDALGO L.

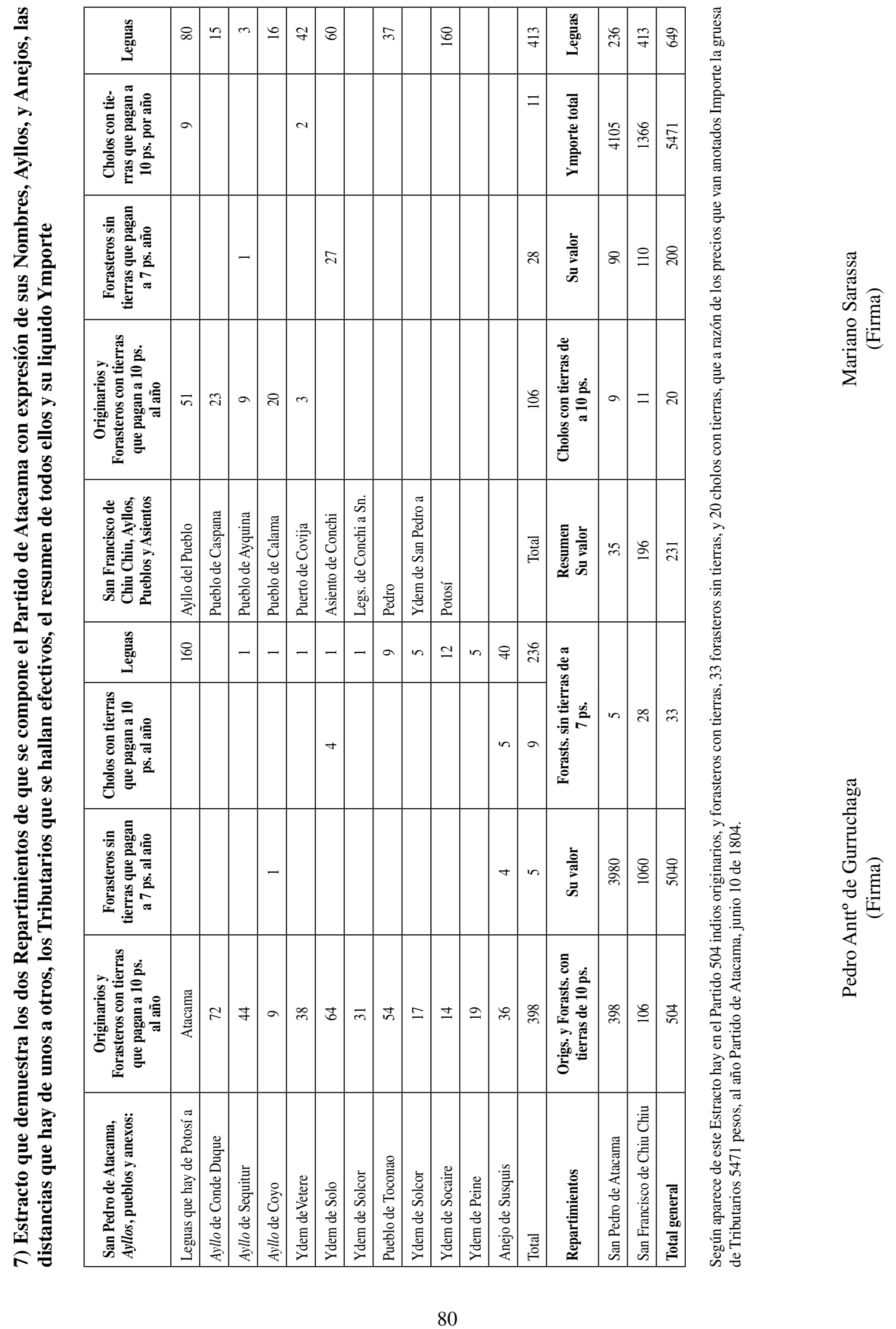


INCIDENCIAS DE LOS PATRONES DE POBLAMIENTO EN EL CALCULO...

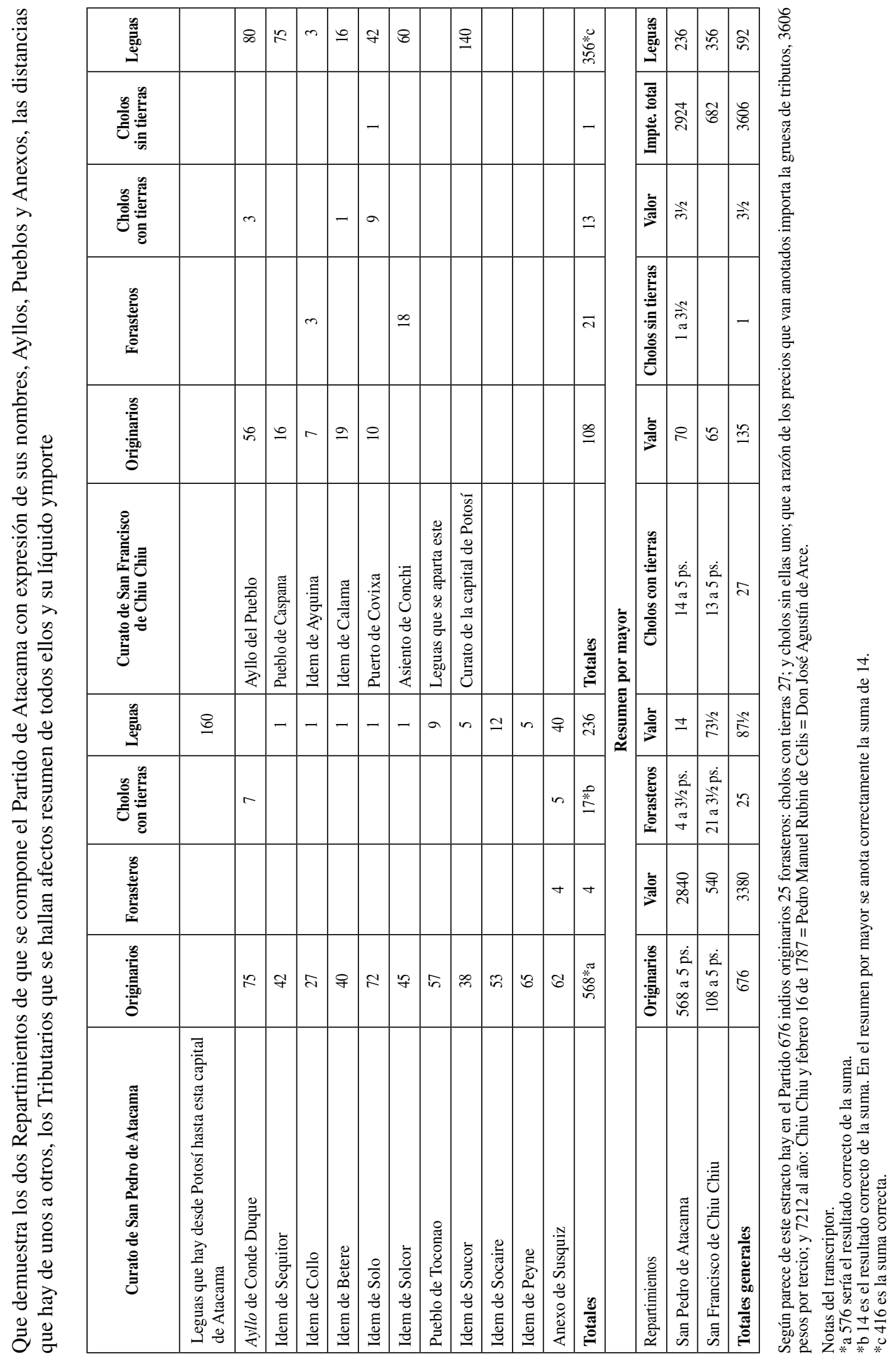


JORGE HIDALGO L.

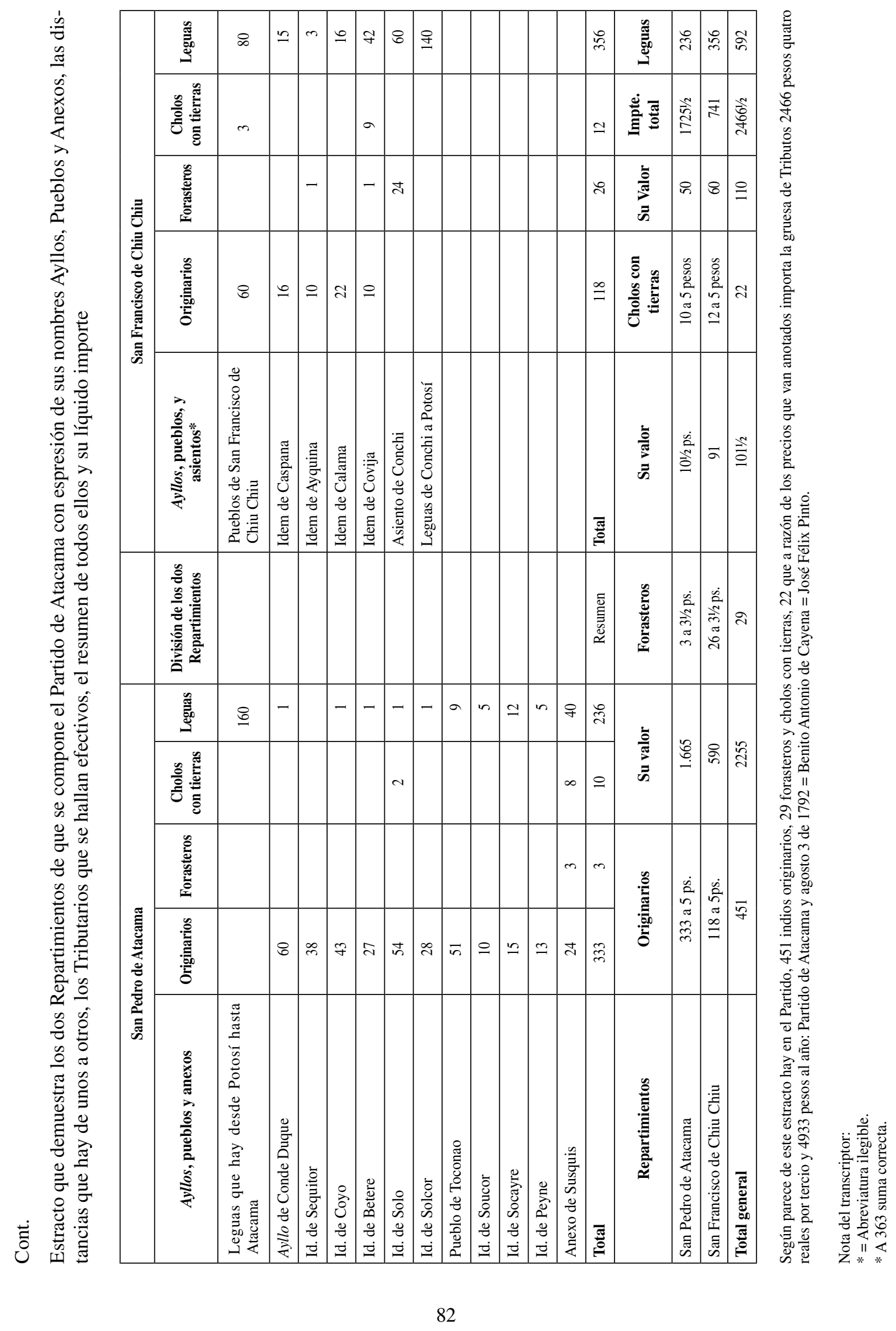




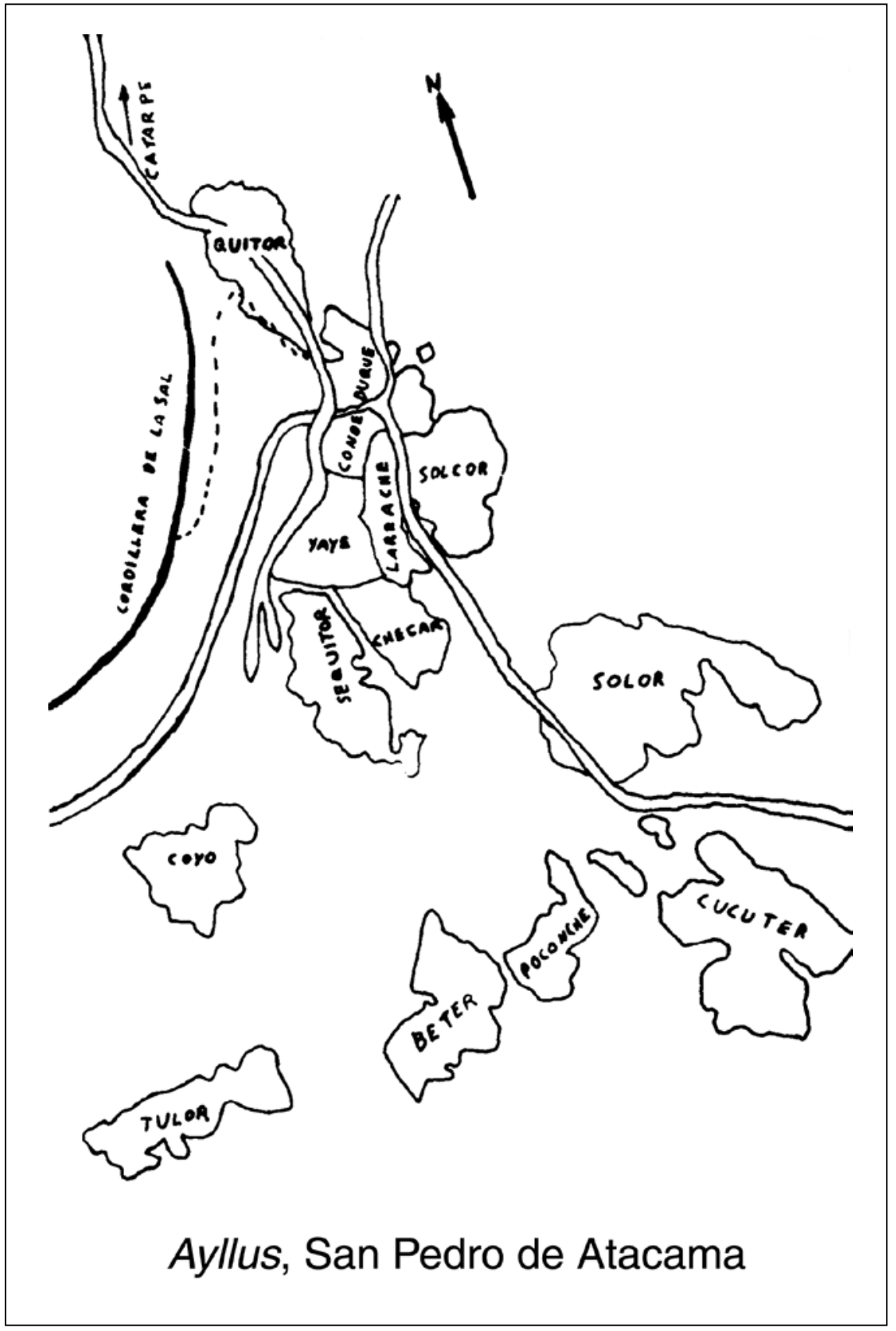




\section{8) ATACAMA}

QUADERNO PRIMERO $1^{\circ}$

\section{Empieza a correr esta Revisita desde el Tercio de San Juan de 1804.}

\section{Testimonio de la Revisita, Numeración, y Empadronamiento de Yndios, practicada en el veneficio de San Pedro de Atacama por su Juez Real Subdelegado Don Pedro Antonio de Gurruchaga [rúbrica]}

Por quanto se alla concluida la Revisita, Numeración, y Empadronamiento de los Yndios y /f1r. Cholos tributarios de este Partido en todos sus Pueblos, Ayllos, y Parcialidades, que se inició en la Capital de San Pedro de Atacama y se terminó en este Asiento de Conchi —últimoPueblo de la Doctrina de San Francisco de Chiu Chiu, atendiendo á lo que previene el Artículo quarenta y tres de la Instrucción Metódica, que se saquen dos Testimonios autenticos del Empadronamiento relaivo, a cada Pueblo, Ayllo, Parcialidad, o Anejo,/ destinados, para que el vno se reparta á los Governadorcs y Caciques exactores, a fin de que no difieran tiempo en la Recaudación, y entero que deven hacer del presente Tercio de San Juan de este año de mil ochocientos quatro; y que el otro se remita á los Señores Ministros de Real Hacienda de la Villa de Potosí, para que en vista de la dicha Matrícula, formen él cargo que corresponda. Cumplase en todo, y por todo lo que previene él nominado Artículo, sacándose los dos citados Testimonios, por el Orden con que se hallan Matriculados, especificando en ambos él nombre del Tributario, él de su Mujer, Hijo, Hijo, ó allegados que pasen de trece años/ los que se denominan por Próximos en él artículo treinta y seis, y para que no se siga demora en él Entero, entreguese él uno a cada uno de los Caciques, Cobradores, y demas Individuos, en quienes recae el cargo de la Covranza, haciéndoles presente la obligación que les asiste de dar el efectivo cumplimiento en él tiempo estipulado, arreglandose á la cuota, y numero de Tributarios, que de el conste a cada Tercio, según él resumen que de ellos ha de haver por conclusion; y él otro remitase a los Ministros de Real Hacienda, de la Citada Villa de Potosí; a cuia Real Caxa pertenece, la satisfacción integra de los tributos de este Partido, poniéndose en ambos él concuerda, que los acredite por mi, y con intervención de don Mariano Sarasa Apoderado Fiscal de la presente Revisita, la que presenció con arreglo al citado Capitulo quarenta y tres: y respecto de no restar otra diligencia para dar por conclusa en todas sus partes la referida Revisita, Numeración, / y Empadronamiento por no haver parecido mas familias de Carta Tributaria, ni adquiridose noticia de que las haya, sin embargo de haverse tomado las declaraciones Correspondientes en forma de Derecho á los Governadores, Caciques y Alcaldes de este Partido, para por este medio formar el más exacto escrutinio, se hicieron otras averiguaciones secretas, para evitar qualesquiera perjuicio ál Real Erario, dejando á salvo él derecho de su Majestad (que Dios guarde) por si en algun tiempo resultare aumento por fraude, u ocultación que se justifique. En cuia virtud, tengase por concluida la enunciada Revisita, y atendiendo á lo dispuesto en él capítulo quarenta y nueve de la predicha ynstruccion Metodica; Hágase el Ynforme jurado que abrace todos los puntos prevenidos en él, y remitase al Señor Governador Yntendente de Provincia, para que en su Vista, dé Su Señoría las Providencias que estime de su Superior agrado, y pongase / este Auto por Caveza de los testimonios mandados sacar con separación de Curatos, para Remitir a las dichas Reales Caxas. Asi lo proveo. Mando, y Firmo, Yo Don Pedro Antonio de Gurruchaga Juez Real Subdelegado de Yntendente, y ál presente Revisitador de Yndios en este Partido, de Atacama. Teniente Coronel de Milicias por su Majestad, con las demas Comisiones del Real Servicio: Actuando con Testigos en defecto de Escrivano Publico ni Real. Partido de Atacama, Asiento de Conchi, y Mayo veinte y nueve de mil ochocientos quatro años = Pedro Antonio de Gurruchaga = Testigo Manuel de Bedoya $=$ Alexo Fernandez $=[$ rubrica $]$ 


\section{Primer Repartimiento Cunato de San Pedro de Atacama}

Padron de los Yndios Originarios del Ayllo de Conde Duque, a cargo del Governador don Pedro Gerardo/de la O Lyquitay, Segunda don Diego Martin, Cacique Exactor don Justo Pastor Amacay, y Alcalde don Sevastian Favian.

$\mathrm{f} 3 \mathrm{v}$

$\mathrm{f} 3 \mathrm{v}$

Francisco de Paula Hermano del antecedente de dies y ocho años Soltero ...

Alexo de la Cruz de treinta y seis años Soltero ...

Juan de la Rosa de veinte y ocho años Casado con Maria Asencia ...

Atanacio Acencio Gualar de quarenta y quatro años Casado con Maria Melchora ... Juan de la Cruz Gualar de diez y seis años Soltero

4. Hijo del antecedente ...

5. Josef Baleriano Gualar de trece años Hermano del Antecedente ...

Pascual Bailón Gualar de veinte y dos años Hermano del antecedente Soltero ...

Patricio Larachi de Treinta y dos años Casado con Maria Dionisia ...

6. Vicente Luciano de quince años Hijo del antecedente ...

Josef Gregorio de quarenta y quatro años Casado con Maria de la Presentación ...

Juan Mariano Chasque de quarenta años Casado con Juana Juliana ...

Josef Domingo Chasque de diez y ocho años Soltero ...

Clemente Ceciliano de treinta y cinco años Casado con Maria de la Cruz ...

Juan Bautista Corante de treinta y seis años Casado con Maria Petrona ...

Francisco Tomas Tontillo de quarenta y Siete años Casado con Petrona Cristina ...

Carlos Santos de diez y ocho años Soltero Hijo del Antecedente ...

Eugenio Eva de quarenta y seis años Casado con Manuela del Sacramento ...

Marcos de la Cruz de treinta y seis años Casado con Maria Rosalía ...

7. Josef Diego Barbosa de diez y seis años Hijo de Tomas Barbosa ...

Mariano Fermin Barbosa de veinte y tres años Soltero Hermano del antecedente ...

Francisco de Paula Barvosa de veinte y cinco años Casado con Maria Josefa ...

Baleriano Davales de treinta y cinco años Soltero ... 
Francisco Borja Chaltiquilla de treinta y quatro años Casado con Felicina Bartola ... 36 Juan Antonio Leso de quarenta y seis años Casado con Maria de la Concepcion ... $\quad 37$ Alexandro Leso de treinta y un años Soltero ...

Francisco Antonio Tontillo de quarenta y dos años Casado con Justa Lorenza ... 39

8. Josef Francisco de diez y seis años Hijo del antecedente ...

Manuel de la $\mathrm{O}$ y Leso de quarenta y quatro años Casado con Maria Petrona ...

Manuel Damaso Caqueo de treinta y cinco años Casado con Maria Cepriana ...

Lorenzo Tiburcio Pachao de quarenta y nueve años Casado con Maria Magdalena ...

Diego Matias Lyquitay de treinta y siete años Viudo ...

Asencio Mariano de treinta y un años Viudo ...

Julián Yidefonso Mondaca de treinta y quatro años Casado con Juana de Dios ...

Martin de la Cruz Amacay / de treinta y un años Casado con Juliana Bonifacia ...

Pedro Martin Gualar de veinte y seis años Casado con Maria Joaquina ...

Gaspar Melchor de veinte y seis años Casado con Maria Antonia ...

Gaspar Melchor de veinte y seis años Casado con Maria Anto
. Josef Victorio de diez y seis años Hermano del antecedente ...

Juan Mariano Lyquitay de veinte y ocho años Casado con Maria Casimira ...

10. Josef Sevastian de diez y seis años Sobrino del antecedente

Josef Santos de veinte y cinco años Casado con Dionisa Caruncho ...

Mariano de veinte y seis años Soltero Hijo del finado Acencio Lucas ...

12. Juan Andres de trece años Hijo del Sacristan de la Yglesia Francisco Ceprian Pascual Bailon Lizarazu de diez y ocho años Soltero...

Son en todo Ochenta y cinco Yndividuos los que componen este Padron a saver: trece Proximos á tributar, y setenta y dos de efectivo tributo, los mismos que se hallan Matriculados en la Original de su contesto, y por dichos setenta y dos Tributarios debe enterar su respectivo Cacique trescientos sesenta pesos en cada uno de los tercios de San Juan, y Navidad como liquido, y efectivo Valor de cinco pesos que paga cada uno de los citados Yndios en ciudad de Originarios = Gurruchaga $=$ Sarassa $=$ Padrón de los Yndios Originarios del Ayllo de Sequitur de la misma Doctrina, y Repartimiento, a cargo del Governador don Pedro Gerardo / de la O Lyquitay, su segunda don Diego Martin, Cacique Don Manuel Antonio Chinchilla, y Alcalde Don juán Pedro. 
Mateo Lorenzo de quarenta y tres años Casado con Manuela Santusa ... 1

Juan Gregorio de treinta y cinco años Casado con Maria Patricia ... 2

Martin Feliciano Chinchilla de treinta y tres años Casado con Maria Vrsula ... 3

Ysidro Manuel Chinchilla de treinta y siete años Casado con Maria del Rosario ... 4

1. CIemente Chinchilla de diez y seis años Hijo del antecedente

Josef Tomas de treinta y nueve años Casado con Nicolasa Faviana ...

Pedro Pablo de treinta y seis años Casado con Maria Tomasa ...

Manuel Eufracio de veinte y nueve años Casado con Magdalena Llauco ...

Josef Manuel de veinte y siete años Casado con Ana Condori ...

Josef Casimiro de veinte y quatro años Casado con Aleja Tolavi ...

Josef Joaquin de treinta y tres años Casado con Maria Simona Araya ... $\quad 10$

Lorenzo Tiburcio de quarenta y quatro años Viudo ... 11

Juan Nieves de quarenta y dos años Casado con Maria Asencia ... $\quad 12$

Josef Damaso Chinchilla de veinte y nueve años Casado con Maria Eustaquia ... 13

Diego Cristoval Cavrera de treinta años Casado con Maria Gregoria ... $\quad 14$

Josef Ermenegildo Silti de veinte y ocho años Soltero ... 15

Francisco Tomas Silti de veinte y cinco anos Casado con Maria Torivia ... 16

Manuel Teodoro de quarenta y dos años Soltero ... 17

Mariano Quiñones de veinte y cinco años Casado con Maria de la O ... 18

Nicolas Damaso de quarenta y nueve años Casado con Juana Maria ... 19

Francisco Lorenzo de quarenta y ocho años Casado con Matia Agustina ... 20

Josef Patricio de veinte y seis años Casado con Maria Cecilia ... 21

Francisco Borja de quarenta y ocho años Casado con Juana Melchora ... 22

Josef Lorenzo Celestino de quarenta y dos años Casado con Maria Flora ... 23

Juan Felipe de treinta y tres años Casado con Maria Ygnacia ... 24

Manuel Silvestre Bravo de quarenta y seis años Casado con Maria Josefa Cavrera ... $\quad 25$

Domingo Baras de quarenta y cinco años Casado con Maria Rios ... 26

Pablo Favian Bara de quarenta y dos años Casado con Petrona Paula ... 27

Pedro Pablo Chavez de veinte años Soltero ... 28

2. Manuel Celestino de diez y seis años Hijo de Tomas Celestino

$\begin{array}{ll}\text { Juan Bautista Celestino de veinte y dos años Soltero ... } & 29\end{array}$

Juan Narciso Maisares de quarenta años Casado con Manuela Tomasa ... 30

Enrique de la Cruz de veinte y nueve años Casado con Maria Rosa ... 31

Enrique de la Cruz de veinte y nueve años Soltero Mellizo, y Hermano del antecedente... $\quad 32$

Clemente Nava de veinte y ocho años Casado con Maria Santusa ... 33

Juan Carlos de veinte y ocho años Casado con Maria Josefa ... 34

Manuel de la $\mathrm{O}$, de veinte y cinco años Soltero ...

Tomas Gavino de veinte y nueve años Soltero ... 36

Calisto Carlos Chingolo de veinte y siete años Soltero ... 37

Josef Pablo de veinte años Soltero, Sobrino de Marcos de la Cruz ... 38

$\begin{array}{ll}\text { Diego Martin de veinte años Soltero Entenado de Tomas Moro ... } & 39\end{array}$

Vicente Pablo Reta de veinte y quatro años Soltero ... 40

Josef Patricio Maisares de veinte años Soltero ... 41

Josef Manuel Chavez de diez y ocho años Soltero ... $\quad 42$

Josef Ermenegildo Viltipopo, de diez y ocho años Soltero ... 43

3. Manuel Matias Viltipopo, de diez y seis años Hijo de Maria Timotea

Josef Maria Reta de diez y ocho años Soltero Hijo de la Viuda Narcisa Polonia ...

f7v

(1)

(1)

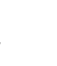

f7

$\mathrm{f} 7 \mathrm{v}$

.

\section{f8r}

8

39
34
36
36

38

9

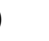

.

3


Son en todo quarenta y siete Yndividuos los que comprehenden este Padrón á saver tres próximos á Tributar, y quarenta y quatro de efectivo Tibuto [sic], los mismos que se hallan Matriculados, en la Original de su contesto y por dichos quarenta y quatro deve enterar, su Respectivo Cacique docientos veinte pesos en cada uno de los Tercios de San Juan, y Navidad, como liquido, y efectivo Valor, de cinco pesos que pagan cada uno de los citados Yndios, en calidad de Originarios $=$ Gurruchaga $=$ Sarassa $=$

Padron de los Tributarios del Ayllo de Coyo de la misma Doctrina, y Repartimiento, Cargo del Governador don Pedro Gerardo de la O Lyquitay, Segunda don Diego Martin Cacique don Josef Joaquin Moro y Alcalde don Bernave Eusevio

Estevan Ciares de treinta y cinco años Casado con Maria Vicenta Moro ...

Pedro Justo Moro de quarenta y tres años Casado con Maria Juliana ...

1. Tomas Ynosencio Moro de trece años Hijo del antecedente

2. Pedro Pablo de catorce años Hijo del Reservado Santos Carlos

Martin Andres Moro de quarenta y ocho años Casado con Maria Manuela ...

Josef Manuel de veinte y dos años Soltero Hijo del Reservado Alejandro Enrique ...

Juan Bernardo de quarenta años Casado con Francisca Paula ...

3. Pascual Vicente de diez y siete años Soltero Hijo del antecedente

Tomas Ramos de treinta, y nueve años Casado con Maria Feliciana ...

Diego Tomas de veinte y nueve años Casado con Maria Bartola

Josef Manuel Moro de veinte y ocho años Casado con Maria Dominga ...

Jelis Gregorio Romero de treinta y siete años Casado con Maria Casimira ...

4. Juan Gerardo de quince años Hijo de Maria Getrudis ...

Josef Manuel Cayo de treinta años Casado con Maria Jacinta Vilca ...

Son en todo catorce Yndividuos los que componen este Padron á saver: Próximos ál Tributo quatro, y de efectivo tributo diez, los mismos que se hallan matriculados, en él Original de su contexto, y por dichos diez Tributarios, deve enterar su Cacique respectivo cincuenta pesos en cada uno de los Tercios de San Juan y Navidad, como liquido, y efecto Valor de cinco pesos que paga cada uno de los citados Yndios Tributarios en Calidad de Originarios $=$ Gurruchaga $=$ Sarassa $=$

Padron de los Tributarios del Ayllo de Vetere de la misma Doctrina y Repartimiento, al/ Cargo del Governador don Pedro Gerardo de la O Lyquitay Segunda don Diego Martin $\mathrm{P}$ Cacique don Josef Joaquin Moro, y Alcalde don Pedro Felipe.

Lucas Agustin de quarenta y nueve años Casado con Maria Santusa Moro ...

Juan Matias Moro de quarenta y nueve años Casado con Maria Rosalia ...

Manuel Espíritu de veinte y cinco años Casado con Petrona Paula ...

Zeledonio Ramos de treinta y un años Casado con Maria Fulgencia ...

Salvador Cayetano de treinta y seis años Casado con Manuela Felipa ...

Simon Josef de treinta y tres años Casado con Maria Lorenza ...

Josef Ramos Rodrigo de veinte y cinco años Casado con Maria Santusa ...

Josef Benito de quarenta y tres años Casado con Juana Paula Mondaca ...

Josef Ermenegildo Moro de veinte años Casado con Maria Martina Barvosa...

Alexandro Julian Moro de veinte y ocho años Casado con Petrona Luysa ... 10

Josef Tomas Moro de veinte y cinco años Casado con Maria Eulalia ... 11

Francisco Tomas Moro de treinta y quatro años Casado con Dionicia Gonzalez ... 12

Francisco Martinez de veinte y cinco años Casado con Petrona Catalina ... 13

Juan Bentura Herrera de treinta y nueve años Casado con Maria Josepha ... 14

Juan de Mata Basualdo de quarenta y nueve años Casado con Andrea Manuela ... 15

Josef Ancelmo Basualdo de diez y ocho años Hijo del antecedente ... 16 
Antonio Bacilio Rodrigo de quarenta y nueve años Casado con Juana Catalina ...

Josef Mariano Rodrigo de veinte años Soltero ...

Juan Ancelmo Rodrigo de veinte y nueve años Casado con Maria Juliana ...

Juan Gregorio Ramos de treinta, y seis años Casado con Bernarda Morales ...

Josef Bernardo Ramos de / treinta y nueve años Viudo ...

Francisco Ramos de diez y ocho años Soltero Hijo del antecedente ...

Josef Gregorio de treinta y tres años Casado con Maria Josefa Taroco ...

Pedro Santos de treinta y dos años Casado con Petrona Cayetana ... 24

Manuel Pablo de treinta y dos años Casado con Maria Ermenegilda... 25

Marcos Bernavé de quarenta y quatro años Casado con Petrona Josefa... 26

Josef Mariano de veinte años Soltero Hijo del antecedente .... 27

Andrés Ygnacio Herrera de treinta, y ocho años Casado con Maria Ancelma ... 28

Mariano Ramos de treinta y quatro años viudo... 29

Josef Joaquin Moro de veinte y un años Soltero ... 30

Miguel Geronimo Herrera de veinte y dos años Casado con .Marta Asencia... 31

Juan Andres Soltero de veinte años Hijo de Mauricio ... 32

Miguel Geronimo Moro de veinte y quatro años Viudo ... 33

Josef Felis de veinte y seis años Soltero...

Melchor Reyes de veinte y dos años Casado con Maria Ermenegilda ...

1 Mariano Cruz Rodrigo de quince años Soltero

2 Pablo Ermitaño de quince años Hijo del Reservado Juan Gregorio

3 Josef Miguel Moro de quince años

4 Francisco Julián de catorce años Hijo del Reservado Bernavé Eusevio

Josef Gervacio de diez y ocho años Soltero Hijo de Maria Dominga 36

5 Josef Yginio de diez y siete años Soltero Hijo de Petrona Melchora

Julian Bernavé Herrera de diez y ocho años Soltjero 37

Josef Francisco Rodrigo de diez y ocho años Soltero 38

Son en todo quarenta y tres Yndios los que comprehende este Padron á saver: Proximos al Tributo cinco, y de efectivo Tributo treinta y ocho, los mismos que se hallan Matriculados en él Original de su contexto, y por dichos treinta y ocho Tributarios deve enterar su Respectivo Cacique ciento noventa pesos en cada uno de los Tercios de San Juan y Navidad, como liquido, y efectivo Valor de cinco pesos que paga cada uno de los citados Yndios, Tributarios en Calidad de Originarios $=$ Gurruchaga $=$ Sarassa $=$

Padron de los Tributarios del Ayllo Solo de la misma Doctrina, y Repartimiento á cargo del Governador don Pedro Gerardo de la O Lyquitay, su Segunda don Diego Martin, Cacique don Juan Gregorio Miranda y Alcalde don Ysidro Ynga.

Cayetano Ramos de treinta años Casado con Maria Josefa ...

Agustin Victorio Flores de quarenta años Casado con Cayetana Romano ...

Felipe Santiago de treinta y seis años Casado con Maria Francisca ...

Manuel Fulgencio de treinta y un años Casado con Josefa Reyes ...

Yanuario Eustaquio de quarenta y quatro años Casado con Maria del Rosario ...

Ancelmo Ramos de treinta y cinco años casado con Maria Justa ... 6

Juan Manuel Ramos de treinta y dos años Casado con Maria Clemencia...

Pedro Fermin de treinta y seis anos Casado con Isavel Maria ... 
Francisco Xavier de treinta y tres años Casado con Maria Justa ...

Rafael Ramos de veinte y nueve años Casado con Paula Marcela ... 10

Gaspar Mariano Ramos de veinte y cinco años Casado con Petrona Ygnacia ... 11

Josef Maria Ramos de veinte años Soltero ... $\quad 12$

1. Pascual Matias Ramos de diez y siete años Soltero

Pedro Mariano Santos de veinte y nueve años Casado con Maria Luysa ... 13

Francisco de Paula Sandon de quarenta y quatro años Casado con Maria Gregoria ... $\quad 14$

2. Juan Manuel Sandon de quince años Hijo del antecedente

Josef Patricio de quarenta y nueve años Casado con Maria Barvara ...

$\mathrm{P}$

Miguel Gregorio de diez y ocho años Soltero Hijo del antecedente ... 16

Domingo Nieves de veinte y nueve años Casado con Maria Josefa ...

3 Josef Nazario de diez, y seis años Hijo del Reservado Asencio Mariano

Asencio Mariano de quarenta y nueve años Viudo ...

Pedro Pablo Bedoya de veinte años Soltero ...

4. Pedro Regalado Fernandez de catorce años

Josef Bernardo Fernandez de veinte años Soltero ...

Juan Ancelmo de treinta y tres años Casado con Petrona Cepriana ... 21

Mariano Eduardo de veinte y dos años Soltero ... 22

Mariano de la Cruz de quarenta años Casado con Maria Eugenia ... 23

5. Manuel Feliciano de diez y seis años Hijo del antecedente

Camilo Siares de treinta y tres años Casado con Maria Ysidora .,. 24

Melchor Gaspar de quarenta y siete años Casado con Maria Josefa ... 25

Juan Crisostomo de veinte y quatro años Casado con Maria Ysidora ... 26

Domingo Ylario de quarenta y siete años Casado con Juana Ysavel ... 27

Francisco Gregorio Ramos de veinte y quatro años Soltero ... 28

Josef Felis Ramos de veinte y quatro años Soltero ...

Nicolás Ambrosio de quarenta y nueve años Casado con Juana Ysidora ... 30

Mariano Gcronimo de quarenta y cuatro años Soltero ... 31

Josef Torivio de quarenta y seis años Casado con Maria Getrudiz ... 32

Francisco de Paula de quarenta y seis años Casado con Maria Candelaria... 33

6. Gregorio Magno de catorce años Hijo del antecedente

Josef Joaquin Baldivieso de veinte y quatro años Soltero ...

Teodoro Chavez de quarenta y tres años Casado con Maria Eustaquia ...

7. Josef Ancelmo de diez y siete años Hijo del antecedente

Raymundo Beltran de treinta y seis años Viudo ... 36

Carlos Eduardo de treinta y quatro años Casado con Manuela Sacramento ... 37

Bemave Ydefonso de treinta y ocho años Casado con Juana de Dios... 38

Patricio Ysidro Romero de treinta y seis años Casado con Maria Manuela ... 39

Josef Felis Romero de treinta, y quatro años Casado con Maria Manuela ... 40

Josef Maria Castucho de treinta y cinco años Casado con Maria Tiburcia ... 41

Juan Santos de treinta y seis años Viudo ...

Felis Mariano Cruz de treinta y un años Casado con Maria Trinidad ... 43

Manuel Antonio Ynga de veinte y ocho años Casado con Juana Petrona ... 44

Pedro Pablo Castucho de treinta y seis años Soltero ... 45

Juan Casimiro Romero de treinta y dos años Casado con Maria Eusevia ... 46

Josef Leandro Ynga de veinte años Soltero ...

Manuel Espíritu Ramos de veinte y nueve años Casado con Petrona Melchora ... 48

Josef Benito Guacas de veinte y nueve años Casado con Juana Cruz ... 
Manuel Mariano Ramos de veinte y cinco años Soltero ... 50

Asencio Mariano Quiroga de veinte y ocho años Soltero ... 51

Francisco Xavier Ramos de veinte y ocho años Soltero ...

Jorge Matias Ramos de veinte y cinco años Soltero ... 53

Josef Ramos de veinte y cinco años Soltero ... 54

Miguel Geronimo Ynga de treinta y dos años Casado con Petrona Fernanda ...

Josef Narciso de veinte y cinco años Casado con Maria Martina ...

Josef Ramón Ramós de veinte años Soltero ...

Alexandro Cruz de veinte y un anos Soltero ...

Damaso Atamayo de quarenta y un años Casado con Maria Josefa ... 59

Mariano Eduardo Beltran de diez y ocho años Soltero ... 60

Juan Bautista de diez y ocho años Soltero ...

Felipe Ramos de diez y ocho anos Soltero ...

Manuel Asencio Paula de diez y ocho años Soltero ...

8 Pascual Agustin Ramos de catorce años Hijo de Maria Gregoria

9 Josef Santos de catorce años Hijo de Maria Loreta

10 Juan Agustín de catorce años Hijo del Reservado Juan Bentura

Josef Ancelmo de diez y nueve años Soltero Hijo de Juan Gualberto ...

\section{Cholos con Tierras}

Pedro Josef de veinte y un años Casado con Maria Magdalena ...

Clemente Ysidro de veinte años Casado con Maria Marta ... 66

Francisco Borja Catacata de veinte y un años Soltero ... 67

Josef Olivario de veinte y tres años Soltero ...

Son en todo setenta y ocho Yndividuos los que componen este Padron á saver: Proximos á tributar diez, y de efectivo tributo sesenta y quatro Yndios, y quatro Cholos, los mismos que se hallan Matriculados en él Original de su Contexto, y por dichos sesenta y ocho Tributarios deve enterar su Respectivo Cacique tres cientos quarenta pesos cada uno de los Tercios de San Juan, y Navidad, como liquido, y Efectivo Valor de cinco pesos que paga cada uno de los Citados Yndios y Cholos Tributarios en Calidad de Originarios = Guwuchaga $=$ Sarassa $=$

Padron de los Tributarios del Ayllo de Solcor de la misma Doctrina y Repartimiento á cargo del Governador don Pedro Gerardo de la O Lyquitay Segunda Don Diego Martin, Cacique él mismo. / Segunda y Alcalde Don Balentin Siares.

Juan Gualverto de quarenta años Casado con Ysabcl Petrona ...

Pedro Advincula de quarenta y dos años Casado con Juana Petrona

Blas Mariano Zenzano de veinte y seis años Casado con Maria Eularia ...

Mariano Remigio Zenzano de treinta y dos años Casado con Maria Ysidora ...

Marcelo Yidefonso Zenzano de treinta y quatro años Casado con Maria Josefa ...

Juan Manuel Trienta de quarenta, y quatro años Casado con Maria Catalina ... 6

Mariano Adrian Trienta de veinte y cinco años Casado con Manuela Estefania ...

Manuel Silvestre Trienta de veinte años Casado con Juana Estefania ...

Tomas Aquino Duro de quarenta y nueve años Casado con Maria Feliciana ...

Juan Eugenio Caro de quarenta y siete años Casado con Isavel Maria ... 10

Santos Manuel Eraso de treinta y ocho / casado con Atanacia de la Cruz ... 11 f16r 
Juan Casimiro Martinez de quarenta y cinco años Casado con Maria Josefa ... 12

Tomas Aquino Martinez de veinte y cinco años Viudo ... 13

Francisco Blas Duro de quarenta y tres años Casado con Juana Justa ...

Josef Espiritu Duro de veinte años Soltero ...

Juan Manuel Caucota de treinta y quatro años Soltero ... 16

Nicolás Balentin Celis de treinta y un años Casado con Maria Nafcisa Josefa ...

$\begin{array}{ll}\text { Josef Cruz Alvarez de treinta y dos años Soltero ... } & 18\end{array}$

$\mathrm{P}$

Bernardo de la Trinidad Siares de treinta y siete años Casado con Manuela Maria ... $\quad 19$

Francisco Borja Lynares de quarenta y dos años Casado con Maria de la Cruz ... 20

Francisco Bruno Eraso de quarenta y seis años Casado con Maria Santusa ... 21

Bernardo Martinez de quarenta y ocho altos Casado con Maria Mercedes ... 22

Felis Leon de veinte y un años Soltero ... 23

Josef Carlos Ydalgo de veinte y tres años Soltero ... 24

Francisco Xavier Martinez de veinte y dos años Casado con Maria Petrona Caucota ... $\quad 25$

Josef Doroteo Sarasa de veinte años Soltero ... 26

Pascual Bailon de diez y ocho años Soltero ... 27

Josef Rufino Leon de diez y ocho años Soltero ... 28

1. Mateo Eustaquio Guarachi de quince años Soltero

2. Marcos Pontifico Zenzano de trece años á cargo de su Hermano Mariano Remigio

3. Timoteo Leon de catorce años Hijo de la Viuda Maria Gavriela

Josef Manuel Guacachuco de treinta y un años Viudo ...

Forasteros con tierras

Francisco Berna de trienta y cinco años Soltero... 30

Antonio Berna de veinte y quatro años Casado con Juana Paula ... 31

Son en todo treinta y quatro Yndividuos los que componen este Padron á saver: Proximos á tributar tres, y de efectivo Tributo treinta y uno, los mismo que se hallan Matriculados en el Original de su contexto, y por dichos treinta y un Tributarios deve enterar su Respectivo Cacique, ciento cincuenta y cinco pesos en cada uno de / los Tercios de San Juan y Navidad, como liquido, y efectivo Valor de cinco pesos que paga cada uno de los Yndios

Tributarios en Calidad de Originarios $=$ Gurruchaga $=$ Sarassa $=$

Padron de los Tributarios del Pueblo de Toconao de la misma Doctrina y Repartimiento, a cargo del Governador don Pedro Gerardo de la O Lyquitay, Cacique don Sevastian Yldefonso Gonzalez, y Alcalde don Ylario Araya.

$\mathrm{P}$

Gregorio Raimundo Reyes de veinte y cinco anos Casado con Maria Asencia ...

Josef Pablo Benito Reyes de veinte y tres años Soltero ...

Bernardo Lazaro de treinta y un años Casado con Maria Josefa ...

Vicente Luciano de quarenta y un años Casado con Maria Paula...

1. Mariano Feliciano de quince años Hijo del antecedente

Lazaro Resucitado de quarenta y seis años Casado con Maria Eugenia ...

2. Justo Ygnocencio de trece años Hijo del antecedente

Domingo Bonifacio de treinta y seis años Casado con Maria Juana ...

Pascual Ambrosio de quarenta y ocho años Casado con Maria de la Concepción ...

Balentin Luciano de quarenta y un años Casado con Pascuala Vilti ... 
Josef Julian de veinte y seis años Soltero...

Estevan Justo Reyes de veinte y nueve años Casado con Alexandra Patricia ...

Evaristo Ramos de treinta años Casado con Petrona Paula ...

Pedro Nolasco de treinta y ocho años Casado con .Maria Rosa ... 12

3. Felis Estevan de diez y seis años Soltero

Fermin Luciano de treinta y seis años Casado con Nicolasa Ambrosia ...

Francisco Gervacio de veinte y cinco años Soltero ...

Bernardo Marcelo de treinta y siete años Casado con Matiasa Baleriana ...

4 Agustin Crisostomo de catorce años Hijo del antecedente

Josef Matias de quarenta y cinco años Viudo ...

$\begin{array}{ll}\text { Bernardo Lazaro de treinta y un años Soltero .... } & 17\end{array}$

Francisco Xavier de quarenta y ocho años Casado con Francisca Martina ...

Francisco Agustín de treinta y ocho años Casado conJuana Crisostoma ... 19

5 Benancio Mercedes de catorce años Hijo del antecedente

Lucas Estevan Gonzalez de treinta y ocho años Casado con Petrona Paula ...

6 Agustin Eusevio de trece años Hijo de Sevastian Yldofonso Francisco Geronimo de treinta y dos años Casado con Agustina Rosa ...

Juan de Malta de quarenta y dos años Casado con Maria Feliciana.. . 22

7 Andres Mata de diez y siete años Hijo del antecedente

Pascual Asencio Teran de quarenta y tres años Casado con Maria Justa ... 23

Antonio Santos Teran de quarenta y un años Viudo ... 24

Manuel Crispin de treinta y nueve años Casado con Maria Ylaria ... 25

Juan Bautista de treinta y siete años Casado con Maria Dorotea ... 26

Antonio Ygnacio de quarenta y siete años Casado con Maria Josefa ... 27

Josef Pascual de diez y ocho años Soltero Hermano del antecedente ... 28

8 Felis Santiago de trece años Hijo del antecedente

9 Josef Ermenegildo de diez y seis años Hijo del Reservado Tomas Aquino

Matias Antonio de veinte y tres años Casado con Maria Alexandra ...

10 Juan Bautista de diez y seis años Soltero Hijo de la Viuda Maria Manuela Josef Santiago González de diez y ocho años Soltero 30

Martin Chocoar de treinta y seis años Casado con Maria del Carmen ... 31

Julian Cayetano de treinta y siete años Casado con Maria Lorenza ... 32

Francisco Florencio Curucuna de quarenta y cinco años Casado con Pascuala Ramona ...

$\begin{array}{ll}\text { Diego Julian de veinte y siete años Soltero... } & 38\end{array}$

Marcos de la Cruz de veinte y ocho años Soltero ... 39

Nicolas Alexandro de veinte y quatro años Casado con Maria Paula ... 40

Bernardo Reyes de veinte y dos años Casado con Maria Asencia /... 41

Josef Carlos de veinte años Soltero ...

Juan Crisotomo de veinte años Casado con Maria Victoria ... 43

Manuel Ysidro de la Trinidad de veinte años Soltero ... 44

Martin Leon de veinte años Soltera ... 45

Lorenzo Matias de treinta y quatro años Casado con Maria Ylaria ... 46

Mauricio Lino Barquez de veinte y un años Soltero... 47 
Josef Carmen de diez y ocho años Soltero Nieto de Juan Joseph Salinas ...

12. Andres Ambrosio de trece años Hermano del antecedente

13. Juan Estevan de diez y siete años Soltero Hijo de Nicolas Mateo

Pedro Nolasco de diez y ocho años Soltero Hijo de Juan Miguel Mondaca ...

14. Bernardo Marcelo de quince años Hijo de la Viuda Maria Santusa

Juan Melchor Reyes de quarenta y seis años Casado con Manuela Melchora ...

15. Juan Antonio de diez y seis años Soltero del antecedente

$P$

Juan Ysidro Reyes de diez y ocho anos Soltero ...

16. Juan Matias Yapura de catorce años Hijo de Ana Maria Josef Manuel de diez y ocho años Soltero ...

17. Pascual Gonzales de catorce años Hijo de Petrola Barvara

18. Mariano Domingo de quince años Hijo de Juana de Dios

19. Josef Santos de trece años Hijo de la Viuda Manuela Pascuala

20. Andres Diego de trece años Hijo de la Viuda Maria Josefa

21. Justo Gregorio de catorce años Nieto del Reservado Sevastian Ygnacio Chacoar Sevastian Manuel Chocoar de diez y ocho años Soltero ...

Son en todo setenta y seis individuos los que comprehenden este Padron á saver; veinte y dos Proximos a Tributar, y cincuenta y quatro de efectivo Tributo los mismos que se hallan Matriculados en el Original de su contexto, y por dichos cincuenta y quatro Tributarios deve enterar su Respectivo cacique dos cientos setenta pesos en cada uno de los Tercios de San Juan, y Navidad, cocomo [sic] liquido y efectivo Valor de cinco pesos que paga cada uno de los Citados Yndios Tributarios, en Calidad de Originarios = Gurruchaga = Sarassa =

Padron de los Tributarios del Pueblo de Soncor de la misma Doctrina y Repartimiento a cargo del Governador don Pedro Gerardo de la O Lyquitay, Cacique / Don Jopef Patricio Cavía, y Alcalde don Pedro Antonio Favian.

$P$

Juan Julian de treinta y nueve años Casado con Maria Lorenza

Asencio Ysidro Gatacata de quarenta y cinco años Casado con Maria de la O ...

Juan Antonio de treinta y seis años Casado con Maria Dorotea ...

Pedro Pablo Chocoar de quarenta y seis años Casado con Maria Paula ...

Julian Leonardo Chocoar de veinte años Soltero ...

Pascual Romualdo Favian de diez y ocho años Soltero ...

Pascual Lorenzo Favian de veinte años Soltero ...

Saltos Cruz Toroco de veinte y seis años Casado con Maria Josepha

Francisco Xavier Quipildor de veinte ocho años Casado con Maria Manuela...

Pedro Silvestre Favian de veinte y quatro años Viudo ...

Pedro Pablo Favian de veinte y dos años Soltero ...

Pascual Francisco de veinte años Soltero ...

1. Manuel del Sacramento de catorce años al cargo de su hermano Santos Cruz Toroco

Pascual Manuel Reyes de veinte y un años Soltero ...

Martin Francisco Reyes de diez y ocho años Soltero y hermano del antecedente ...

Manuel Justo Catacata de quarenta y quatro años Casado con Maria, Paulina ... 
2. Crisostomo Tiburcio de catorce años Hijo de la viuda Maria Gregoria

Son en todo diez y nueve Yndios los que comprehende este Padrón á saver: dos Proximos a Tributar, y diez y siete de efectivo Tributo, los mismos que se hallan Matriculados en el Original de su Contexto, y por dichos diez y siete tributarios deve enterar su Respectivo Cacique ochenta y cinco pesos en cada uno de los Tercios de San Juan, y Navidad como liquido, y efectivo valor de cinco pesos que paga cada uno de los citados Yndios Tributarios en calidad de Originarios $=$ Gurruchaga $=$ Sarassa $=$

Padron de los Yndios Tributarios del Pueblo de Socaire de la misma Doctrina, y Repartimiento á cargo del Governador don Pedro Gerardo de la O Lyquitay, Cacique don Ysidro Marcelo, y Alcalde don Diego Ambrosio.

$\mathrm{P}$

Pascual Ramón de quarenta y seis años Casado con Maria Manuela ...

Asencio Silvestre de diez y ocho años Soltero ...

1. Vernavé Santos de catorce años Hijo de Ysidro Manteela

Andres Pascual de quarenta y nueve años Casado con Maria Manuela ...

2. Andres Baltasar de quince años Sobrino del antecedente

Asencio Santos de diez y nueve años Soltero ...

Josef Mariano de veinte y tres años Soltero ...

Manuel Pedro de quarenta y nueve años Soltero ...

Lorenzo Yapura de veinte y seis años Casado con Manuela Cayetana ...

Juan Casimiro de treinta y un años Soltero ...

Pedro Ylario de veinte y quatro años Casado con Maria Cecilia ...

Lucas Texerina de veinte y quatro años Soltero Hijo del Reservado Pascual Jacinto...

Sevastian Favian Fernando de quarenta y quatro años Casado con Maria Antonia ...

Juan Torivio de veinte y ocho años Soltero ...

Juan Severo Lera de veinte y ocho años Soltero ...

Mariano Quipildor de diez y ocho años Soltero Hijo del finado Juan Ygnacio Quipildor ...

Son en todos diez y seis Yndios los que componen este Padron á saver; Proximos á Tributar dos, y de efectivo Tributo catorce, los mismos que se hallan Matriculados, en él Original de su contexto, y por dichos catorce Tributarios, deve enterar su respectivo cacique setenta pesos en cada uno de los Tercios de San Juan, y Navidad, como liquido, y efectivo. Valor, de cinco pesos que paga cada uno de los citados Yndios Tributarios, en calidad de Originarios $=$ Gurruchaga $=$ Sarassa

Padrón de los Tributarios del Ayllo, y Pueblo de Paine de la misma doctrina y Repartimiento á cargo del Governador don Pedro Gereado de la O Lyquitay y su Cacique don Julián Morales.

Luys Andres Morales treinta y seis años Casado con Maria Asencia ...

Juan Ysidro Morales de treinta y dos años Soltero ...

Mariano Carlos Morales de veinte y ocho años Soltero ...

Martin Blas de veinte y cinco años Casado con Micaela Geronima ...

Bernardino Yldefonso de treinta y cinco años Casado con Maria Barvara ...

Manuel Santiago de diez y ocho años Soltero Hijo del antecedente ...

Pascual Manuel de quarenta y seis años Viudo ...

Matias Mariano de veinte años Soltero ...

Agustin Lorenzo de quarenta y ocho años Casado con Maria Gandida ...

Francisco Nicolas de quarenta y seis años Soltero ...

Ysidro Reyes de treinta y quatro años Viudo ... 
Francisco Mariano de veinte y un años Casado con Maria Candelaria ...

Julian Bartolome/ Reales de veinte y quatro años Casado con Maria Ysavel...

Blas Reales de veinte y quatro años Soltero ...

Pedro Julian de veinte y dos años Soltero Nieto del Reservado Josef Dionisio ...

Son en todo diez y diez y nueve Tributarios los que componen este Padrón los mismos que se hallan Matriculados en él Original de su contexto, y por dichos diez y nueve Tributarios deve enterar su Respectivo Cacique noventa y cinco pesos en cada uno de los Tercios de San Juan, y Navidad, como liquido, y efectivo Valor de cinco pesos que paga cada uno de los Citados Yndios Tributarios en Calidad de Originarios $=$ Gurruchaga $=$ Sarassa $=$

f24r.

Padrón de los Tributarios Originarios, y Forasteros del Ayllo, y Pueblo de Susquis de la misma Doctrina y Repartimiento á cargo del Governador don Pedro Gerardo de la O Lyquitay, Segunda y Cacique don Josef Antonio Reyes, y Alcaldes don Josef Mariano $\mathrm{P}$ Pyneyra, y don Juan Pascual Favian.

1. Faustino Reyes de trece años Hijo de Josef Antonio Reyes

2. Julian Josef Pineyra de quince años Hijo de Josef Mariano Pineyra

Francisco Rosario Basques de treinta y seis años Casado con Andrea Paula

3. Josef Laureano Basques de diez y siete años Soltero Hijo del antecedente Josef Balentin / Salvador de treinta y un años Casado con Josefa Carvajal ... Pedro Pablo Salvador de quarenta y quatro años Viudo ...

Josef Benito Salva de diez y ocho años Soltero ...

Martin Favian Vilti de quarenta y tres años Casado Maria Dionicia Basques ... Josef Ancelmo Vilti de veinte años Soltero...

Ylario Teodoro Basques de treinta y quatro años Casado con Jacinta Cayo Miguel Geronimo Basques de veinte ocho años Casado con Maria Luysa ... Francisco Balentin Basques de quarenta y tres años Casado con Juana Maria... Pedro Florentino Basques de treinta y seis años Casado con Pascuala Josefa ...

4. Pascual Reyes Basques de catorce años Hijo del antecedente

Sevastian Pucapuca de treinta y seis años Casado / con Maria Petrona ...

Ysidro Pucapuca de quarenta y seis años Casado con Maria Bernarda ...

Josef Prudencio Pucapuca de diez y ocho años Soltero ...

Diego Pablo de quarenta y quatro años Casado Petrona Oropesa ...

Juan Carvajal de treinta y nueve años Casado con Maria Jacinta ...

Josef Roque Soriano de quarenta y tres años Casado con Maria de la Candelaria ...

5. Mauricio Grimaldo Soriano de catorce años Hijo del antecedente...

Josef Santos Soriano de veinte y dos años Soltero ...

Josef Leonardo Soriano de diez y ocho años Soltero ...

Bernardo Carvajal de treinta y quatro años Casado con Pascuala Quespi...

Tomas Pucapuca de quarenta y quatro años Casado con Bateriana Aramayo ...

Tiburcio Pucapuca de diez y ocho años Soltero ...

Fulgencio Bonifacio Cruz de treinta y un años Casado con Francisca Barvara... 22

Bictorio Basques de treinta y tres años Casado con Maria Luysa ... 21

Eusevio Basques de treinta y siete años Casado con Juana Rufina ...

6. Tomas Baldes de diez y seis años Soltero Hijo del Reservado Josef Baldes ...

Pedro Santos Salva de quarenta años Casado con Bartóla Arias ...

Mateo de Basques de treinta y seis años Casado con Francisca Rosalía ... 26

Justo Pastor de diez y nueve años Soltero ...

Sevastian Favian Basques de veinte y dos años Casado con Eusevia Norverta ... 28 
Josef Santos Basques de diez y nueve años Soltero ... 29

Ysidro Ramos de veinte años Soltero ...

Josef Bonifacio de veinte y un años Soltero ...

Josef Atanacio Toconas de veinte y un años Soltero ... 32

Balentin Cepriano Pineyra de diez y ocho años Soltero ... 33

Josef Bernardino Vilti de veinte y dos años Casado con Juana Crisostoma ...

Mariano Ramos de veinte y un años Soltero ...

Manuel Cruz Buques de véinte y dos años Soltero ... 36

\section{Cholos Originarios con Tierras}

Ysidro Josef Pineyra de diez y ocho años Soltero ... 37

Alexandro rios de treinta y un años Viudo ... 38

Cristoval Pineyra quarenta y quatro años Casado con Juana Sevastiana ... 39

Francisco González de treinta y / quatro años Casado con Juana Juliana ... $\quad 40$ 226v.

Pedro Manuel Pyneyra de veinte y tres años Soltero

Forasteros sin Tierras de a tres pesos quatro reales

Diego Oropesa de quarenta y nueve años Casado con Petrona Paula...

7. Alexo Oropesa de diez y seis años Soltero Hijo del antecedenteDomingo Ramos de quarenta y quatro años Casado con Andrea Paula ...

Tomas Aquino Pineyra de diez y siete años Soltero, Hijo del Reservado Andres Pascual

8. Pineyra

Pablo Mamani de veinte y cinco años Casado con Jacinta Basques...

Antonio Mamani Cruz de veinte y quatro años Casado con María Josefa Benancia ...

Son en todos cincuenta y tres Yndividuos los que comprehenden este Padrón á saver; Ocho

proximos á Tributar, y quarenta y cinco de Efectivo Tributo, los mismos que se hallan Matriculados en él Original de su contexto, y por dichos quarenta y cinco Tributarios, deve enterar sus respectivo Cacique la Cantidad de dos cientos diez y nueve pesos, en cada uno de los Tercios de San Juan, y Navidad, como liquido, y efectivo Valor de cinco pesos que pagan cada uno de los treinta y seis indios, y cinco cholos / Originarios con Tierra, y tres pesos quatro reales, cada uno de los quatro forasteros $\sin$ Tierra $=$ Gurruchaga $=$ Sarassa $=$ Concuerda este Testimonio Original de su contexto y con él que queda repartido por Padrones, á los Govomadores, Principales, y Caciques Covradores, y uno, y Otro, estan fiel, y legalmente Sacados, Corregidos y Concertados, como previene el Artículo quarenta y tres de la Ynstruccion de Revisitas, á que en lo necesario me remito; Y para su mayor validacion, interpongo mi Autoridad, y/Judicial Decreto, Yo don Pedro Antonio de Gurruchaga Juez Real Subdelegado de Yntendente, y al presente Revisitador de Yndios de este Partido, actuando con Yntervencion del Apoderado Fiscal don Mariano Sarassa, y con Testigos en defecto de Escrivano Publico ni Real. Partido de Atacama asiento de Conchi y Mayo veinte y nueve de mil ochocientos quatro años.

Pedro Antonio Gurruchaga testigo Manuel de Bedoya

Mariano Sarassa testigo Alexo Fernandez 


\section{ATACAMA \\ QUADERNO SEGUNDO $2^{\circ}$ \\ Empieza á correr esta Revisita desde el Tercio de San Juan de 1804}

Testimonio de la Revisita, Numeración, y Empadronamiento de los Yndios, practicada en el veneficio de San Francisco de Chiu Chiu, Atacama la vaja, por su Juez Real Subdelegado don Pedro Antonio de Gurruchaga.

Por quanto se halla concluida la Revisita, Numeración, y Empadronamiento de los Yndios, y Cholos Tributarios de este Partido, en todos sus Pueblos, Ayllos, y Parcialidades, que se ynició en la Capital de San Pedro de Atacama, y se terminó en este Asiento de Conchi, último Pueblo de la Doctrina de Chiu Chiu: Atendiendo á lo que previene el Articulo quarenta y tres de la Ynstruccion Metodica que se saquen dos Testimonios autenticos del Empadronamiento, relativo a cada Pueblo, Ayllo, Parcialidad, o / Anejo, destinados, para que él uno se reparta a los Gobernadores, y Caciques exactores, a fin de que no difieran tiempo en la recaudacion, y entero que deven hacer del Presente Tercio de San Juan de este año de mil ochocientos quatro; y que él otro se remita a los Señores Ministros de Real Hacienda de la Villa de Potosi, para que en vista de dicha Matricula formen él cargo que corresponda. Cumplase en todo, y por todo la que previene el nominado Articulo, sacándose los dos citados testimonios por el orden con que se hallan Matriculados, especificando en ambos él nombre del Tributario, el de su Muger Hijo, Hijos, o allegados que pasen de trece años, los que se denominan por Proximos en él Articulo treinta y seis, y para que no se / siga demora en el entero entreguese el uno, a cada uno de los predichos Caciques cobradores, y demas Yndividuos, en quienes recae el cargo de la Cobranza, haciéndoles presente la Obligación que les asiste de dar él efectivo cumplimiento, en el tiempo estipulado, arreglandose á la cuota y Numero de Tributarios que de el conste en cada Tercio, según el resumen que en ellos ha de aver por conclusion, y él remitase, á los Señores Ministros de Real Hacienda, de la citada Villa de Potosi, á cuia Real Caxa pertenece, la satisfaccion integra de los Tributos de este Partido, poniéndose en ambos él concuerda que los acredite por mi, y con yntervencion de do Mariano Sarassa, Apoderado Fiscal de la presente Revisita, la que presenció con arreglo al citado Capitulo quarenta y tres: Y respecto de no restar otra diligencia, para dar por / conclusa en todas sus partes la referida revisita. Numeracion, y Empadronamiento, por no haver mas familia de Casta Tributaria, ni adquiridose noticia de que las aya, sin embargo de haverse tomado las declaraciones correspondientes en forma de derecho, á los Governadores, Caciques, y Alcaldes de este Partido, para por este medio formar el mas exacto escrutinio, se hicieron otras averiguaciones secretas, para evitar cualquier perjuicio al Real Erario, dejando á salvo él derecho de su Magestad (Dios le guarde) por si en algún tiempo resultare aumento, por fraude u ocultación que se justifique: en cuia virtud tengase por concluida la enunciada Revisita, y atendiendo á lo dispuesto en él Capitulo quarenta y nueve de la predicha Ynstruccion Metodica, hagase el Ynforme jurado, que / abrace todos los puntos prevenidos en él, y remitase al Señor Governador Yntendente de Provincia, para que en su Vista de Su Señoría, las Providencias que estime de su Superior agrado, pongase este auto por caveza de los Testimonios mandados sacar, con separación de Curato, para remitir á las dichas Reales Caxas. Asi lo proveo, mando, y firmo. Yo don Pedro Antonio de Gurruchaga, Juez Real Subdelegado de Yntendente, y al presente revisitador de Yndios de este Partido de Atacama; Teniente Coronel de Milicias por Su Magestad, con las demas Comiciones del Real Servicio: actuando con Testigos en defecto de Escrivano Publico ni Real. Partido de Atacama, Asiento de Conchi, y Mayo veinte y nueve de mil ochocientos quatro años $=$ Pedro Antonio de Gurruchaga $=$ Testigo Manuel de Bedoya $=$ Testigo Alejo Fernandez $=$

\section{Secundo Repartimiento Curato de San Francisco de Chiu Chiu}

Padron de los Tributarios del Pueblo de San Francisco de Chiu Chiu, a cargo del covernador don Juan Felis Gutierez, Segunda don Pabalo Palalo, cacique don Fernando Mariano Cruz, y Alcalde don Francisco Rafael Mondaca. 
Julian Cruz de treinta y cinco años Casado con Maria Eugenia Caur ... Marcelo Machaca de quarema y nueve años Casado con Maria Magdalena Palalo ... 2 Pedro Alexandro Villanueva de quarenta y cinco años Casado con Juliana Toquintoco 3 Josef Venticolas / de veinte y seis años Casado con Maria Anastacia..... Tomas Lyquitay de treinta años Casado con Nicolasa Flores ... Gregorio Liquitay de veinte y ocho años Casado con Maria Nieves ... 6 Nicolas Peres de quarenta y cinco años Casado con Maria Aquino ... Josef Antonio Perez de diez y ocho años Soltero ... Alejo Berna de veinte y ocho años Casado con Maria Dorotea Lyquitay ...

Marcos Fernando Cruz de treinta años Sohero...

Pedro Ylario Cruz de veinte y siete años Casado con Antonia Carrasana ... Josef Cayetano Cruz de treinta y cinco años Casado con Polonia Apasa... Josef Marcelino Cruz de veinte y dos años Casado con Ysavel Copa... Eusevio Baltasar Lyquitay de quarenta y un años Casado con Juana Luysa ... Carlos Yauco de treinta y cinco años. Casado con Maria Nieves... Josef Mariano Aquino de veinte y dos años Casado con Eugenia Tolavi...

Julian Venticolas de treinta y nueve años Casado con Casimira Viltipopo... Francisco Xavier Tassar de veinte y dos años Soltero...

Bernardo Gutierres de treinta y seis años Casadedo con Maria Francisca...

Manuel Mondaca de veinte y siete años Soltero...

1. Josef Blas Cayo de quince años Soltero Hijo del antecedente...

Estevan Venticolas de treinta y tres años Casado con Justa Panini...

2. Juan Bautista Avendaño de catorce años Hijo del antecedente...

Julian Cruz Chinchilla de veinte y nueve años Casado con Maria Clemencia... 41

Gregorio Chinchilla de veinte y seis años Casado con Manuela Colamar... 42

Nicolas Lyquitay de veinte y nueve años Casado con Maria de la O... 43

.

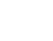

34

6

37
8


Francisco Xavier Lyquitay de veinte y siete años Soltero...

Simon Lyquitay de veinte y cinco años Soltero...

Norverto Cruz de veinte y ocho años Casado con Maria de la O Toquintoco... 46

Manuel Cruz de treinta y seis años Casado con Gervacia Esperanza...

Ysidoro Viltipopo de treinta y seis años Casado con Maria Manuela... 48

3. Yosef Vicente Gutierrez de trece años Hijo del Ympedido Francisco Gutierrez...
Pedro Josef Gutierrez de veinte y dos años Soltero...

Josef Lyquitay de veinte y dos años Casado con Manuela Condori... 50

Josef Benito Chaturquina de veinte años Soltero ... 51

\section{Cholos con Tierras}

4. Francisco Xavier Catati de quince años Soltero Hijo del Sacristan de la Yglesia Raimundo Catati

Fernando Chaves de treinta y siete años Casado con Maria Josefa Caur ... 52

Pablo Mauricio Chaves de quarenta y seis años Casado con Maria Catalina ... 53

Josef Manuel Galleguillos de veinte y tres años Casado con Micaela Nieves ... 54

$\mathrm{P}$

Manuel Eusevio Villanueva de veinte y tres años Casado con Maria Ysidora Pascuala ... 55

Remigio Venticolas de veinte y dos años Soltero... 56

Josef Ysidro Fernandez de veinte y dos años Soltero ...

Josef Felis Mondaca de veinte y quatro años Casado con Manuela Viltipepo ... 58

Pedro Josef Viltipopo de diez y ocho años Soltero ...

Josef Mauricio Palalo de diez y ocho años Soltero... 60

Son en todo sesenta y quatro Yndividuos los que comprehenden este Padron á saver: Proximos á Tributar quatro, y de efectivo Tributo sesenta, los mismos que se hallan Matriculados, en el Original de su contexto, y por dichos cincuenta y un Yndios Tributarios, y nueve cholos, deve enterar su respectivo Cacique trescientos pesos en Cada uno de los Tercios de San Juan, y Navidad, como liquido, y efectivo Valor de cinco pesos que paga cada uno de los citados Yndios, y Cholos, en calidad de Originarios = Gurruchaga $=$ Sarassa

Padron de los Yndios Tributarios del Ayllo y Pueblo de Caspana de la misma Doctrina, y Repartimientos á cargo del Governador don Juan Felis Gutierres, Segunda don Pablo Palalo, Cacique don Martin Severino Colamar, y Alcalde don Juan Santos Teran.

f7r.

$\mathrm{P}$

Pascual Reyes de quarenta y tres años Casado con Juana Micaela ...

Ylario Teran de veinte y seis años Casado con Maria Bernarda Colamar ...

Antonio Geronimo Teran de veinte y tres años Soltero ...

Josef Manuel Teran de veinte años Soltero ...

Pedro Casimiro Lyquitay de treinta y tres años Casado con Manuela Panini... 5

Domingo Carvajal de treinta y un años Soltero ...

Pascual Lyquitav de treinta y un años Casado con Petrona Lyquitay ...

$\begin{array}{ll}\text { Andres Geronimo Saire de veinte y siete años Soltero ... } & 8\end{array}$

Josef Julian Saire de veinte años Soltero ...

Diego Martin Colamar de quarenta años Casado con Maria Luysa Lyquitay...

1. Josef Romualdo Colamar de quince años Soltero...

2. Justo Rufino Colamar de catorce años

Sevastian Colamar de/ veinte y cinco años Casado con Juana Luysa Saire...

3. Santos Patricio Teran de diez y seis años Soltero

Josef Estanislao Saire de veinte y cinco años Casado con Maria Andrea Carvajal ... 
Josef Guillermo Saire de diez y ocho años Soltero...

Pedro Josef Saire de diez y ocho años Soltero ...

Juan Santos Lyquitay de treinta y seis años Casado con Maria Tomasa ...

Josef Manuel Ramos de veinte y dos años Soltero ... 16

Ventura Carvajal de veinte y seis años Soltero ... 17

Dionicio Lyquitay de treinta y cinco años Casado con Juana Monica Palalo 18

Ceprian Colamar de veinte y seis años Casado con Maria Simona ... 19

Juan Pastor Caucota de veinte y cinco años Casado con Juana Juliana Lyquitay 20

Josef Donato de veinte y un años Soltero ... 21

Josef Benito Lyquitay de veinte y un años Casado con Maria Paula ... 22

Manuel Felis Paniri de quarenta y dos años Casado con Maluela de la Trinidad 23

f8r.

4 Josef Lyquitay de catoce años Soltero Sobrino de la Viuda Basilia Petrona Lyquitay

Son en todo veinte y siete Yndividuos los que comprehenden este Padron a saver: Proximos á Tributar quatro, y de efectivo Tributo veinte y tres, los mismos que se hallan Matriculados en él Original de su Contexto, y por dichos beinte y tres Tributarios, deve enterar su respectivo cacique ciento quince pesos cada uno de los Tercios de San Juan, y Navidad, como liquido, y efectivo valor de cinco pesos que paga cada uno de los citados Indios en calidad de Originarios $=$ Gurruchaga $=$ Sarassa $=$

Padron de los Tributarios del Ayllo, y Pueblo de Ayquina de la misma Doctrina, y Repartimiento, á cargo del Governador don Juan Feliz Gutierres, Segunda don Pablo Palalo, Cacique don Martin Severino Colamar, y Alcalde don Francisco Berna.

Juan Santiago Colamar de treinta y dos años Casadeeon Maria de la O ...

Martin Bonifacio Paniri de veinte y seis años Casadacon Maria Norverta Saire ...

Gervacio Paniri de treinta y cinco años Soltero ...

Alejo Paniri de treinta y ocho años Casado con Maria LuysaViltipopo ...

Josef Gregorio Paniri de veinte y cinco años Soltero ...

Felipe Venito Viltipopo de veinte y tres años Casado con Maria Marcelina ...

Juan Casimiro Palalo de quarenta y quatro años Casado con Maria Silvestra ...

Juan Geronimo Berna de treinta y quatro años Casado con Juana Estefa...

Josef Lorenzo Paniri de veinte y tres años Soltero ...

1 Juan Ygnacio Paniri de catorce años Hijos del Reservado Lucas Paniri

\section{Forasteros sin Tierra}

2 Ygnocencio Choque de catorce años Hijo del Reservado Carlos Choque

Bentura Choque y ocho años Soltero...

Son por todo los Yndividuos que comprehenden este Padron á saver: Proximos a Tributar dos, y de efectivo Tributo diez, los mismos que se hallan Matriculados en el Original de su contexto, y por dichos diez tributarios deve enterar su respectivo Cacique quarenta y ocho pesos quatro reales, en cada uno de los Tercios de San Juan, y Navidad, como liquido, y efectivo valor de cinco pesos que paga cada uno de los citados Yndios Originarios con tierras que son nueve, y un Forastero sin ellas, tres pesos quatro reales $=$ Gurruchaga $=$ Sarassa $=$

Padron de los Tributarios del Ayllo, y Pueblo de Calama de la misma Doctrina, y Repartimiento a cargo del Governador don Juan Felis Gutierrez, Segunda don Pablo Palalo, Cacique don Josef Mamani y Alcalde don Pascual Bernardo Palalo.

Juan Andres Nieves de quarenta y quatro años Casada con Maria Santusa ...

Eusevio Venticolas de veinte y cinco años Viudo ... 
Pablo Nieves de veinte y dos años Soltero ...

Mariano Nieves de veínte y dos años Casado con Juana Gregoria Viltipopo ... 4

Ytario Flores de quarenta y seis años Casado con Maria Isavel ...

Ygnacio Flores de treinta y ocho años Casado con Maria de la Encamación ... 6

1 Eusevio Flores de quince años Soltero Hijo del antecedente

Miguel Geronimo Salvador de treinta y ocho años Casado con Maria Ramona ... 7

Nicolas Baltasar de treinta y cinco años Casado con Maria Paula ... 8

Josef Mariano Nieves de treinta y siete años Casado con Maria Cepriana ...

2 Josef Eugenio de trece años Sobrino del antecedente

Juan Josef Artinti de veinte y dos años Casado con Maria Yauco... 10

3 Josef Leon Gomez de diez y siete años Soltero

Marcelo Carvajal de treinta años Soltero ...

Pedro Carvajal de treinta años Casado con Maria Eustaquia ...

4 Josef Benito Carvajal de quince años Hijo del antecedente

Martin Carvajal de veinte y cinco años Soltero...

Basilio Flores de treinta años Casado con Maria Josefa ...

Narciso Reta de veinte y siete años Casado con Maria Narcisa ...

5 Josef Eugenio Reta de trece años Hijo del antecedente

f9v.

(1)

(1)

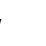

f10r.

Josef Damaso Reta de veinte y quatro años Soltero ...

$\begin{array}{ll}6 & \text { Felipe Leon de diez y siete años Soltero Hijo de la Viuda Marcelina Nieves ... } \\ \text { Pedro Josef Mamani de veinte y dos años Soltero... } & 20\end{array}$

Son en todos veinte y seis Yndividuos los que componen este Padron, á saver: seis Proximos a tributar, y veinte de efectivo Tributo, los mismos que se hallan Matriculados en el Original de su contexto, y por dichos veinte Tributarios, deve enterar su respectivo Cacique cien pesos, en cada uno de los Tercios de San Juan, y Navidad, como liquido, y efectivo Valor, de cinco pesos que paga uno de los citados Yndios en Calidad de Originarios $=$ Gurruchaga $=$ Sarassa $=$

Padron de los Yndios Tributarios que comprehende él Puerto de Covija de la misma Doctrina, y Repartimiento, á cargo del Governador Cacique don Juan Josef Armendariz.

$\mathrm{P}$

Juan de la Cruz Cotaypi de veinte y cinco años Soltero ...

Josef Severino Cotaypi años Soltero ...

Justo Sajaya de veinte y nueve años Soltero ...

\section{Cholos con Tierras}

Juan Josef Sajaia de treinta y cinco años Casado con Maria ríos ...

Francisco Sajaya de veinte y ocho años Casado con Josefa Maturana ...

Son en todos cinco años los que comprehenden este Padron, á saver tres Yndios, y dos Cholos con tierras, los mismos que se hallan Matriculados en el Original de su contexto, y por dichos cinco Tributarios deve enterar su respectivo Governador Cacique veinte y cinco pesos en cada uno de los Tercios de San Juan y Navidad, como liquido y efectivo valor de cinco pesos que paga cada uno de los Yndios y Cholos en calidad de Originarios $=$ Gurruchaga $=$ Sarassa $=$

Padron de los Forasteros sin Tierras del Asiento de Conchi de la misma Doctrina, y f11v. Repartimiento á cargo del Governador don Juan Felis Gutierres, Segunda don Pablo Palalo, y Alcalde Cacique don Damaso Tolavi. 
Pedro Cayo de quarenta y dos años Casado con Ysavel Bautista ...

Leocadio Carrasana de quarenta y quatro años Casado con Andrea Totavi...

Josef Manuel Yani de veinte y siete años Casado con Santusa Copa ...

Josef Antonio Yani de veinte y quatro años Casado con Esperanza Carvajal ...

Severino Carrasana de veinte años Casado con Maria Mamani...

Josef Damián Sollaso de veinte y dos años Soltero ...

Basilio Sollaso de treinta y seis años Casado con Manuela Condori ...

Nicolás Tolavi de veinte y nueve años Casado con Maria Viltipopo ...

Manuel Barvosa Tolavi de treinta y quatro años Soltero ...

Pedro Tolavi de quarenta y un años Soltero ...

Mariano Ambrosio Tolavi de treinta y seis años Casado con Teresa Salvatierra ...

Ancelmo Gregorio Tolavi de treinta y nueve años Casado con Maria Sollaso ...

Tomas Tolavi de treinta y siete años Casado con Juana Petrona ...

1 Josef Benito Talavi de diez y seis años Hijo del antecedente

Pascual Tolavi de treinta y nueve años Viudo ...

2 Favian Tolavi de trece años Hijo del antecedente

Josef Copa de diez y ocho años Soltero Hijo del Reservado Ignacio ...

Ysidro Bautista de diez y ocho años Soltero ...

Josef Copa de quarenta y nueve años Casado con Maria Mamani ...

Santiago Copa de treinta años Casado con Maria Rosa Cayo ...

Josef Apasa de treinta y tres años Soltero ...

Lorenzo Aymani de treinta años Casado con Maria Yere ...

3 Juan Josef Yere de catorce años Hijo del antecedente

Francisco Aymani de veinte y siete años Casado con Maria Mamani... 21

Manuel Aymani de veinte y quatro años Soltero ... 22

Fernando Palliri de veinte y un años Casado con Damiana Salvatierra ... 23

4 Francisco Palliri de catorce años Hermano del antecedente

Mariano Copa de veinte y un años Soltero ...

Josef Manuel Gomez de veinte y un años Soltero ...

5 Josef León Gomez de diez y siete años Soltero Hermano del antecedente Dionisio Carvajal de quarenta y quatro años Casado con Francisca Quespi... Marcos Mamani de treinta y tres años Casado con Juliana Mamani ...

Son por todos treinta y dos Yndividuos los que comprehenden este Padron, á saver: Proximos a Tributar cinco, y de efectivo Tributo veinte y siete los mismos que se hallan Matriculados en el Original de su contexto, y por dichos veinte y siete Tributarios, deve enterar su respectivo Cacique noventa y quatro pesos quatro reales, en cada uno de los tercios de San Juan, y Navidad, como liquido, y efectivo Valor de tres pesos quatro reales que paga cada uno de los citados Yndios, en $/$ calidad de Forasteros sin tierras $=$ Gurruchaga $=$ Sarasa $=$

f13v.

Concuerda este Testimonio con él Original de su contexto, y con él que queda repartido por Padrones, á los Governadores Principales, y Caciques Cobradores uno y otro estan fiel, y legalmente sacados, corregidos, y concertados, como previene él Articulo quarenta y tres de la Ynstruccion Metodica de Revisitas, á que en lo necesario me remito, y para su maior validacion, interpongo mi autoridad, y Judicial Decreto Yo don Pedro Antonio de Gurruchaga, Juez Real Subdelegado de Yntendente, y ál presente Revistador de Yndios de este Partido, actuando con / intervención del Apoderado Fiscal don Mariano Sarassa, y con Testigos en defecto de Escrivano Publico ni Real, Partido de Atacama Asiento de Conchi, y Mayo veinte y nueve de mil ochocientos quatro años.

\author{
Pedro Antonio de Gurruchaga \\ testigo Manuel de Bedoya
}

Mariano Sarassa

testigo Alexo Fernandez 


\section{Indice onomástico de los documentos ${ }^{1}$}

Amacay, Dn. Justo Tattof. (Cacique exactor del ayllo de Conde Duque). Raf3v.

Ambrosio, Dn. Diego. (Alcalde del pueblo de Socaire). Raf21v. Araya, Dn. Ylario. (Alcalde del pueblo de Toconao) Raf$17 \mathrm{r}$.

Arce, Doctor José Agustín de (Apoderado fiscal, 1787). Mr27r. Mf45r. M131r. Mf36r. Mf41r.

Annendariz, Dn. Juan Josef. (Gobernador y cacique de puerto de Cobija). Rbfl0v.

Arredondo. Mf42r.

Bedoya, Manuel de. (Testigo). Raf3r. Raf28r. Rbf3v. R6fl4r.

Berna, Dn. Francisco (Alcalde del ayllo y pueblo deAyquina). Rbf8r.

Bernal, Matias. Mf34r. Mf37r. Mf40r.

Cabrera. Mf42r.

Cayena, Benito Antonio de. Mf47r.

Colamar, Dn. Martin Severino. (Cacique del ayllo y pueblo de Caspana) Rbf6v.

Colamar, Dn Martín Severino. (Cacique del ayllo y pueblo de Ayquina). Rbf8r.

Cruz, Dn. Femando Mariano. (Cacique del pueblo de San Francisco de Chiuchiu). Rbf3v.

Chinchilla, Dn. Manuel Amonio. (Cacique del ayllo de Sequitur). Raf7r.

De La O Liquitay, Pedro Gerardo. (Gobernador del curato de San Pedro de Atacama). Raf3r/f3v. Raf6v/f7v. Raf-9r. Raf10r. Raf12r. Raf15r. Raf17r. Raf20r. Raf21v. Raf22v. Raf24r.

Escobedo, Dn. Jorge. (Visitador General del Reino). Mf29r.

Eusevio, Dn. Bernave. (Alcalde del ayllo de Coyo). Raf9r.

Favian, Dn. Juan Pascual. (Uno de los dos alcaldes del ayllo y pueblo de Susquis). Raf24r.

Favian, Dn. Pedro Antonio. (Alcalde del pueblo de Soncor). Raf20v

Favian, Dn. Sevastian. (Alcalde del ayllo de Conde Duque). Raf3v.

Felipe, Dn. Pedro. (Alcalde del ayllo de Betere) Raf10r.

Fernandez, Alexo. (Testigo). Raf3r. Raf28r. Rbf3v. Rbf14r.

Gavia, Dn Josef Patricio. (Cacique del pueblo de Soncor). Raf20r/f20v.

Gonzales, Dn. Sevastian Yldefondo. (Cacique del pueblo de Toconao). Raf17r.

Gurruchaga, Dn. Pedro Antonio. (Juez Real Subdelegado de Intendente y revisitador de indios en Atacama, Teniente Coronel de Milicias, 1804). Raf3r. Raf6v. Raf9r. Raf9v. Raf11v. Raf15r. Raf17r. Raf20r. Raf21v. Raf22v. Raf23v. Ral27v. Raf28r. Rbf3r. Rbf6v. Rbf8r. Rbf9r. Rbf10v. Rbf11r. Rbf13v. Rbf14r. R-Extracto.
Gutierrez, Dn. Juan Felis. (Governador del Repartimiento de San Francisco de Chiuchiu). Rbf3v. Rbf6v. Rbf8r. Rbf9r. Rbf11v.

Mamani, Dn. Josef. (Cacique del ayllo y pueblo de Calama). Rbf9r.

Marcelo, Dn. Ysidro. (Cacique del pueblo de Socaire). Raf21v. Martín, Dn. Diego. (Segunda persona del Gobernador fiel curato de San Pedro y cacique del ayllo de Solcor). Raf3v. Raf7r. Raf9r. Raf10r. Rf12r. Raf15r.

Matta. Mf42r.

Miranda, Dn. Juan Gregorio. (Cacique del ayllo Solo). Raf12r.

Mondaca, Dn. Francisco Rafael. (Alcalde del pueblo de San Francisco de Chiuchiu). Rbf3v.

Morales, Dn. Julian. (Cacique de ayllo y pueblo de Peine). Raf22v.

Moro, Dn. José Joaquín. (Cacique del ayllo de Coyo y del ayllo de Betere, ¿son la misma persona?). Raf9r. Raf10r.

Palalo, Dn. Pablo. (Segunda del Gobernador de Chiuchiu, Juan Felis Gutierrez) Rbf3v. Rbf6v. Rbf8r. Rbf9r. Hbf11r.

Palalo, Dn. Pascual Bernardo. (Alcalde del ayllo y pueblo de Calama). Rbf9r.

Pedro, Dn. Juan. (Alcalde del ayllo de Sequitur). Raf7r.

Pinedo. Mf42r.

Pino Manrrique, Doctor Juan del (Intendente de Potosí). Mf28r. Mf29r.

Pinto, José Félix. Mf47r.

Pyneyra, Dn. Josef Mariano. (Uno de los dos alcaldes del ayllo y pueblo de Susquis). Raf24r.

Reyes Don Josef Antonio (Segunda persona del Gobernador Pedro de la $\mathrm{O}$ y cacique del ayllo y pueblo de Susquis). Ral24r.

Rubin de Celix, Pedro Manuel. (Subdelegado del partido de Atacama). Mf27r. Mf31r. Mf36r. Mf41r. Mf45r.

Sanz, Don Francisco de Paula. (Subdelegado). Mf29r.

Sarasa, Don Mariano (Apoderado fiscal de la Visita de 1804). Ra12r. Raf6v. Raf9r. Raf9v. Raf11v. Raf15r. Raf17r. Raf20r. Raf21v. Raf22v. Raf23v. Raf27v. Ral28r. Rbf2r. Rbf6v. Rbf8r. Rbf9r. Rbf10v. Rbf11r. Rbf13v. Rbf14r. Rb-Extracto.

Siares, Don Balentis. (Segunda y alcalde del ayllo de Solcor). Raf15v.

Teran, Don Juan Santos. (Alcalde del ayllo y pueblo de Caspana). Rbf6v.

Tolavi, Don Damaso. (Alcalde-cacique del asiento de Conchi). Rbf11v.

Velasco. Mf42r.

Vedasco, Pedro de Mf42r.

Velles, Manuel José de. (Secretario de la Intendencia de Potosí). Mf28r.

Ynga, Don Ysidro. (Alcalde del ayllo Solo). Raf12r.

1 Se excluyen los nombres de los tributarios. 


\section{Indice toponímico de los documentos}

Arauco. (Mencionado por error). Mf31r.

Atacama la Baja. Véase Chiu Chiu.

Atacama, Partido de. Mf24r. Mf29r. Mf31r. Mf33r. Mf36r. Mf37r. Mf38r. Mf41r. Mf45r. Mf47r. Raf3r. Raf28r. Rbfl4r. R-Extracto.

Ayquina (Aquina), ayllo y pueblo de. Mf45r. Mf47r. Rbf8r R-Extracto.

Betere (vetere), ayllo de Mf45r. Mf47r. Raf10r. R-Extracto. Buenos Ayres (Aires), Virreinato de. Mf34r. Mf36r. Mf40r. Mf41r.

Calama, ayllo y pueblo de. Mf45r. Mf57r. Rbf9r. R-Extracto. Caspana, ayllo y pueblo de. Mf45r. Mf47r. Rbf6v.

Chiuchiu, San Francisco de (ayllo, pueblo, curato, doctrina, veneficio, repartimiento). Mf27r. Mf45r. Mf47r. Rbf1r. Rbf3v. R-Extracto.

Collo (Coyo), ayllo de. Mf45r. Mf47r. Raf9r. R-Extracto.

Conchi, asiento de. Mf24r. Mf45r. Mf47r. Raf1r. Raf3r. Raf28r. Rbf1r. Rbf11v. Rbfl4r. R-Extracto.

Conde Duque, ayllo de. Mf45r. Mf47r. R4f3r. R-Extracto.

Covija (Covixa), puerto de. Mf45r. Mf47r. Rbf10v. R-Extracto.
Pacages, partido de. Mf32r.

Peine (peyne), ayllo y pueblo de. Mf26r. Mf45r. Mf47rr. Raf$22 \mathrm{v}$. R-Extracto.

Potosí. Mf28r. Mf29r. Mf34r. Mf45r. Mf47r. R-extracto.

Intendencia de. Mf24r. Mf37r.

Provincia de. Mf31r. Mf36r. Mf41r Mf42r.

Villa de. Rafv. Raf2r. Rbf1v. Rbf2r.

Salta, Intendencia de. Mf25r.

Provincia de. Mf29r.

San Pedro de Atacama, capital del partido, curato de, repartimiento de, venneficio de. Mf24r. Mf45r. Mf47r. Raf1v. Raf3r Rbflr. R-Extracto.

Sequitur, ayllo de. Mf45r. Mf47r. Raf6v. R-Extracto.

Socaire (Socaipe, Socayre), pueblo de Mf26r. Mf45r. Mf47r. Raf21v. R-Extracto.

Solcor, ayllo de. Mf45r. Mf47r. Raf15r. R-Extracto.

Solo, ayllo de. Mf45r. Mf47r. Raf12r. R-Extracto.

Soncor (Soucor), pueblo de. Mf26r. Mf45r. Mf47r. Raf20r. R-Extrarto.

Susquis (Susquiz), Anexo de, ayllo y pueblo de. Mf45r. Mf47r. Rf24r. R-Extracto.

Toconao, pueblo de. Mf26r. Mf45r. Mf47r. Raf17r. R-Extracto. Tucumán, jurisdicción de. Mf24r. Mf26r. 